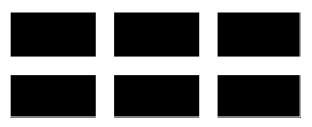

ThE WILliam DAVIDSON INSTITUTE

AT THE UNIVERSITY OF MICHIGAN

\title{
Inflation Targeting in Brazil, Chile and South Africa: An Empirical Investigation of Their Monetary Policy Framework
}

\author{
By:Mona Kamal
}

William Davidson Institute Working Paper Number 1004 November 2010 


\title{
Inflation Targeting in Brazil, Chile and South Africa: An Empirical Investigation of Their Monetary Policy Framework ${ }^{I}$
}

\author{
Mona Kamal \\ M.Sc in Economics \\ Queen Mary, University of London \\ E-mail: economist.researcher@gamil.com
}

\begin{abstract}
$\underline{\text { Abstract }}$
This paper tackles the monetary policy performance in Brazil, Chile and South Africa under inflation targeting framework. Furthermore, it provides an empirical assessment through using the unrestricted Vector Auto-regression (VAR) and Structural Vector Auto-regression (SVAR) approaches depending on data spans the period from the first quarter of 1970 to the fourth quarter of 2007. On the other hand, it utilizes the Likelihood Ratio (LR) Statistic to test for possible structural changes due to the adoption of inflation targeting regime in those countries.

The main findings are as follows: inflation targeting does make a difference in the performance of monetary policy in those countries. Furthermore, the experience of Brazil, Chile and South Africa provides important lessons for other emerging market economies to adopt such a framework.
\end{abstract}

Keywords: Monetary policy, Vector Auto-regression (VAR), Structural Vector Auto-regression (SVAR) approach, Inflation Targeting Framework.

JEL Classifications: E52, E58.

\footnotetext{
1 The views expressed in this paper are those of the author and do not necessarily represent those of any institution the author is affiliated to.

- This paper represents the outcome of work prepared by the author to obtain the M.Sc in Economics from Queen Mary, University of London under supervision of Dr. Ana Galvão Ferreira.
} 


\section{Introduction:-}

There is no doubt that many countries have adopted comprehensive reforms towards the independence of their central banks. One of the remarkable changes in conducting monetary policy is the widespread adoption of inflation targeting by many industrialized countries as well as emerging market economies since 1990s. This option has followed the unsuccessful adoption of monetary targeting regimes or using exchange rates as nominal anchors.

According to Mishkin (2000), inflation targeting has several advantages as a medium-term strategy for the implementation of monetary policy. In contrast to an exchange-rate peg, inflation targeting enables monetary policy to focus on domestic considerations and to respond to shocks to the domestic economy. Furthermore, in contrast to monetary targeting, inflation targeting has the advantage that a stable relationship between money and inflation is not critical to its success, but instead it uses all available information to determine the best settings for the instruments of monetary policy. Inflation targeting also has the key advantage that it is highly transparent.

This paper assesses the monetary policy performance in Brazil, Chile and South Africa. It illustrates the main reasons behind the adoption of inflation targeting framework. Furthermore, it provides empirical investigation through using the unrestricted Vector Auto-regression (VAR) and Structural Vector Auto-regression (SVAR) approaches to investigate the responses of inflation rates and output gap to monetary policy shocks as well as a simple Likelihood Ratio (LR) Statistic to test for structural changes due to the adoption of inflation targeting regime. The data spans the period from the first quarter of 1970 to the fourth quarter of 2007.

The paper is organized as follows: Section 2, illustrates the conceptual framework of inflation targeting regime. Section 3, provides an overview of the relevant literature. Section 4, represents an overview of the monetary policy framework in Brazil, Chile and South Africa and the reasons behind the adoption of inflation targeting. Section 5, shows the estimation approaches and the main results. Finally, I conclude. 


\section{Conceptual Framework:-}

Inflation targeting is a monetary-policy strategy that encompasses five main elements; (1) the public announcement of medium-term numerical targets for inflation; (2) an institutional commitment to price stability as the primary goal of monetary policy, to which other goals are subordinated; (3) an information-inclusive strategy in which many variables, and not just monetary aggregates or the exchange rate, are used for deciding the setting of policy instruments; (4) a transparent monetary policy strategy $\stackrel{2}{=}$ that ascribes a central role to communicating to the public and the markets (the plans, objectives, and rationale for the decisions of the central bank); and (5) mechanisms that make the central bank accountable for attaining its inflation objectives.

Inflation targeting is usually formalized in agreements between the central bank and government, a regulation, or a statement announcing the targets. Central banks generally have instrument autonomy. Government is responsible for setting the target either independently or jointly with the central bank. This is particularly the case for developed economies. In those countries, government may also have an override provision for a certain period, in case of policy differences, that is subject to public disclosure and appeals process.

The following subsections indicates the main classification of inflation targeting regimes, the prerequisites that have to be fulfilled by the country and how to model the inflation targeting strategy.

\subsection{Classification of Inflation Targeting Regimes:}

Carare and Stone (2006) have provided a classification of inflation targeting countries into three regimes. The regimes are defined by the clarity and credibility of the central bank's commitment to the inflation target. Clarity is gauged by the public announcement of the inflation target and by the institutional arrangements in support of accountability to the target. Credibility is proxied by the actual inflation outturn and by market ratings of long-term local currency government debt.

\section{- Full-Fledged Inflation Targeting (FFIT):-}

It is the best-known form of inflation targeting. In this regime, countries have a medium to high level of credibility, clearly commit to their inflation target, and institutionalize this

\footnotetext{
$\underline{2}$ In practice, openness and transparency in the conduct of monetary policy in an inflation targeting framework have been promoted by the regular publication of an Inflation Report, which sets out the central bank's analysis of recent economic developments, and a forecast of inflation as well as other variables including output over the coming year or years. Refer to Agénor (2000).
} 
commitment in the form of a transparent monetary framework that fosters accountability of the central bank to the target. New Zealand was the first country to adopt (FFIT), and by 2001 some seven industrial ${ }^{3}$ and eleven emerging market ${ }^{4}$ countries were practicing this regime.

- Implicit Price Stability Anchor (IPSA) ${ }^{5}$ :-

In this regime, countries have so much credibility that they can maintain low and stable inflation without full transparency and accountability with respect to an inflation target. Their record of low and stable inflation and high degree of financial stability affords them the flexibility to pursue the objective of output stabilization, as well as price stability. Five developed countries that their central banks are classified as practicing (IPSA), including the European Central Bank and the Board of Governors of the Federal Reserve System. $\underline{6}$

\section{- Inflation Targeting Lite (ITL):-}

Countries announce a broad inflation objective but owing to relatively low credibility are not able to maintain inflation as the foremost policy objective. Their relatively low credibility reflects their vulnerability to large economic shocks and financial instability and a weak institutional framework. The number of (ITL) countries is nineteen and all are emerging market countries. $^{7}$

\subsection{Prerequisites of the Adoption of Inflation Targeting Regime:-}

As Amato and Gerlach (2002) have mentioned, one essential precondition is the independence of the central bank. There is broad agreement that instrument independence ${ }^{8}$ is desirable for good monetary policy, whatever the exact policy framework. Goal independence, however, appears to be less important.

\footnotetext{
$\underline{3}$ Those countries are New Zealand, Canada, United Kingdom, Sweden, Australia, Iceland and Norway.

${ }^{4}$ Chile, Brazil, Czech republic, Israel, Poland ,Columbia, Hungary, Mexico, Korea, South Africa and Thailand.

5 Carare and Stone have referred to the second classification of inflation targeting as Eclectic Inflation Targeting (EIT) -in an old version of their paper- See, Carare and Stone (2003). Whereas, the two authors refereed to it as Implicit price stability anchor (IPSA) in a recent version of their paper dated 2006. Both (EIT) and (IPSA) refer to the same characteristics. However, the former is widely used in the monetary policy literature.

${ }^{6}$ It also includes the central banks of Singapore, Switzerland, and Japan.

7 Croatia, Peru, Philippines, Uruguay, Slovenia, Algeria, Guatemala, Jamaica, Slovak Republic, Dominican Republic, Albania, Kazakhstan, Mauritius, Indonesia, Honduras, Russia, Romania, Sri Lanka and Venezuela.

$\underline{8}$ There are three notions of independence as illustrated by Bofinger (2001):-

- Goal independence: requires that the government has no direct influence on the goals of the monetary policy.

- Instrument independence: requires that the central bank be able to set its operating targets (interest rate, exchange rate) autonomously.

- Personal independence: requires that the decision-making body of a central bank be in a position to resist
} formal directives as well as informal pressure from the government. 
Bernanke and Mishkin (1997) have showed that the adoption of inflation targeting is often linked with changes in the laws or administrative arrangements associated with the central bank. Typically, reforms are in the direction of increased independence for the central bank, particularly in respect to its choice of instrument settings. This seems to be a logical consequence of making price stability the overriding goal of policy, since the central bank is the best place to make the technical decisions necessary to achieve price stability and to make judgments about whether the pursuit of other objectives is consistent with this goal.

Another precondition is the absence of any firm commitment by the authorities to target the level or path of any other nominal variable, such as wages or, especially, the nominal exchange rate. In fact, a country that chooses a fixed exchange rate system subordinates its monetary policy to the exchange rate objective and is unable to target any other nominal variable on a lasting basis, especially in the presence of capital mobility. ${ }^{9}$

In practice, however, in many of the developing countries those have opted for a de jure flexible exchange rate, monetary authorities have continued to pay considerable attention to the value of the domestic currency often adopting a de facto target path or band. There are various reasons for the central bank to be concerned with nominal exchange rate movements, even when its degree of independence (and thus its ability to commit itself only to the pursuit of price stability) is high. First, the exchange rate has a direct impact on inflation and plays a key role in transmitting monetary policy shocks to prices. If the pass-through effect is indeed high, the central bank may be tempted to intervene on the foreign exchange market to limit currency fluctuations. A high degree of nominal exchange rate instability may also be of concern to policymakers to the extent that it translates into a high degree of variability in the real exchange rate and distorted relative price signals to domestic producers. Another important reason is that in (partially) dollarized economies large fluctuations in exchange rates can lead to banking and financial instability by inducing large portfolio shifts between domestic and foreign currency denominated assets. Finally, in countries where the corporate and banking sectors hold large foreign-currency liabilities, exchange rate depreciations can have significant adverse effects on their balance sheets. This was, indeed, one of the important features of the Asian crisis. $\frac{10}{}$

Sound fiscal policy is also considered as an important precondition. It is easy to see that good government finances are highly desirable. Most obviously, they reduce the risk of the central bank ending up as a residual purchaser of government bonds. Another precondition is that the

\footnotetext{
9 Refer to Masson et al. (1997).

$\underline{10}$ Refer to Agénor (2000).
} 
economy needs to be resilient to changes in exchange rates and interest rates. Since monetary policy under inflation targeting is no longer geared to maintaining a stable external value of the currency, large exchange rate changes can result. Finally, it is frequently argued that, because inflation targeting is a forward-looking monetary policy strategy, there is a need for econometric models of the inflation process and the transmission mechanism. 11

\subsection{Implementing Inflation Targeting: How to Model Such a Framework?}

Svensson (1997) has argued that the solution to the potential problem in implementing inflation targeting consists of making the central bank's inflation forecast an explicit intermediate target. He considered the following model:

$$
\begin{aligned}
& \pi_{t+1}=\pi_{t}+\alpha_{1} y_{t}+\alpha_{2} x_{t}+\varepsilon_{t+1} \\
& y_{t+1}=\beta_{1} y_{t}-\beta_{2}\left(i_{t}-\pi_{t}\right)+\beta_{3} x_{t}+\eta_{t+1} \\
& x_{t+1}=\gamma_{t}+\theta_{t+1}
\end{aligned}
$$

Where $\pi_{t}=p_{t}-p_{t-1}$ is the inflation rate in year $(t), p_{t}$ is the log price level, $y_{t}$ is an endogenous variable representing log output relative to potential output, $x_{t}$ is an exogenous variable, $i_{t}$ is the monetary policy instrument (the repo rate, for instance), and ( $\varepsilon_{t}, \eta_{t}$ and $\left.\theta_{t}\right)$ are independent and identically distributed (i.i.d.) shocks in year ( $t$ ) that are not known in the previous year $(t-1)$. The coefficients $\alpha_{1}$, and $\beta_{2}$ are assumed to be positive; the other coefficients are assumed to be nonnegative; $\beta_{1}$ and $\gamma$ in addition fulfill $\beta_{1}<1, \gamma<1$. The change in inflation is increasing in lagged output and the lagged exogenous variable. Output is serially correlated, decreasing in the lagged real repo rate, $\left(i_{t}-\pi_{t}\right)$ and increasing in the lagged exogenous variable. The long-run natural output level is normalized to equal zero. The monetary policy instrument affects output with a one-year lag, and hence inflation with a twoyear lags. That the instrument affects inflation with a longer lag than it affects output is the crucial property of the model. It is consistent with results from a number of Vector Autoregression (VAR) studies. $\underline{12}$

If monetary policy is conducted by a central bank with an inflation target, then inflation targeting can be interpreted as implying that the central bank's objective in period $(t)$ is to choose a sequence of current and future monetary policy instrument $\left\{i_{t}\right\}_{\tau=t}^{\infty}$, so as to minimize:

\footnotetext{
11 Amato and Gerlach (2002).

$\underline{12}$ For instance, as in Fuhrer and Moore (1995). See, Svensson (1997, p. 1116)
} 
$E_{t} \sum_{\tau=t}^{\infty} \delta^{\tau-t} L\left(\pi_{t}\right)$

Where $\mathrm{E}_{\mathrm{t}}$ denotes expectations conditional upon (the central bank's) information available in year (t), the discount factor $\delta$ fulfills $0<\delta<1$, and the period loss function $L\left(\pi_{t}\right)$ is:

$$
L\left(\pi_{t}\right)=\frac{1}{2}\left(\pi_{t}-\pi^{*}\right)^{2}
$$

That is, the central bank wishes to minimize the expected sum of discounted squared future deviations of inflation from the target. It is crucial here that inflation targeting is interpreted as implying a single goal; that the inflation rate is the only variable in the period loss function (equation (5)).

Furthermore, Svensson (1997) has pointed out that inflation targeting may be implemented by central banks through involving additional goals for output or employment. He has considered a situation when there is a long-run inflation target $\pi^{*}$, but no long-run output target (other than the natural rate of output), since monetary policy cannot affect output in the long run. In the short run, he has supposed that the goal of monetary policy was to stabilize both inflation and output around the long-run inflation target and natural output rate, respectively. Thus, in the goals for monetary policy, there is a symmetry between inflation and output in the short run, but not in the long run. This situation can be described with a period loss function

$$
L\left(\pi_{t}, y_{t}\right)=\frac{1}{2}\left[\left(\pi_{t}-\pi^{*}\right)^{2}+\lambda y_{t}^{2}\right]
$$

Where, $\lambda>0$ is the relative weight on output stabilization. The intertemporal loss function is

$$
E_{t} \sum_{\tau=t}^{\infty} \delta^{\tau-t} L\left(\pi_{t}, y_{t}\right)
$$

So, it is clear that the case examined where inflation rate was the overriding goal corresponds to $\lambda=0$ in equation (6).

Alternatively, Masson et al. (1997) have expressed the implementation of the inflation targeting regime as the following feedback rule:

$$
\Delta \mathrm{R}_{\mathrm{t}}=\gamma\left(\pi_{t+j}^{e}-\pi_{t+j}^{*}\right)
$$

Where, $\left(\mathrm{R}_{\mathrm{t}}\right)$ represents the preferred instrument of monetary policy, $\pi_{k}$ is the rate of inflation in period $k, \pi_{t+j}^{e}$ is the authorities' expected rate of inflation in period $(t+j)$ conditional on information at time $t$ ( assuming no subsequent policy changes), $\pi_{t+j}^{*}$ is the 
inflation target for period $(t+j), \gamma$ is feedback parameter and $(j)$ is the number of periods it takes for the policy instrument $(R)$ to have its maximum effect on inflation.

The feedback rule (8) shows clearly that in order to follow an inflation targeting procedure the monetary authority must have a well-defined inflation target $\left(\pi^{*}\right)$, a preferred policy instrument, approximate knowledge of (j), and some view of the expected rate of inflation in period $(t+j)$. Therefore, what distinguishes inflation targeting from other frameworks for conducting monetary policy, is not the accuracy of the forecasting techniques employed in the procedure but the fact that the setting of policy instrument relies on a systematic assessment of expected inflation, rather than on past or current inflation developments or an otherwise assumption about future inflation.

\section{Review of the Literature:}

A substantial literature has investigated the optimal design of monetary policy framework, for instance: Barro and Gordon (1983), Rogoff (1985), Svensson (1997) suggest that governments have to delegate monetary policy to a central bank that is instrument independent and appropriately conservative $\stackrel{13}{ }$. Central bank independence and conservatism eliminate the inflation bias of monetary policy that results from the incentive to exploit surprise inflation to raise output in the short run above its natural level, which is typically assumed to be inefficiently low. $\stackrel{14}{ }$

Varieties of solutions to the problem of inflation bias have been proposed. One influential mean; is the adoption of inflation targeting; which involves commitment of a central bank to the pursuit of an assigned target. $\underline{15}$

On the other hand, the widespread consensus among central bankers and economists about the importance of inflation targeting as a framework for conducting monetary policy is a result of large debates about two polar strategies, termed "rules" and "discretion".

\footnotetext{
$\underline{13}$ By appropriately conservative, this literature means that the central bank's output and/or inflation targets should be lower than the socially optimal ones and that the central bank should put more weight on inflation stabilization and less on output stabilization than society does. See, Dixit and Lambertini (2003).

For instance, Rogoff (1985, p.1169) has considered an institutional response to the time-consistency problem facing the monetary authority through appointing "conservatives" to head the central bank, or giving the central bank concrete incentives to achieve an intermediate monetary target.

$\underline{14}$ Refer to Dixit and Lambertini (2003).

15 Refer to Woodford (2003).
} 
For instance, the advocates of rules (e.g. the fixed rule for money growth proposed by Milton Friedman or a gold standard) have argued that "tying the hands" of policymakers will prevent the monetary authorities from implementing counter- productive attempts at short-run stabilization and will thus eliminate the inflationary bias inherent in discretionary monetary policy. On the other hand, supporters of discretionary policymaking - under which the central bank is left free to "do the right thing" as economic conditions evolve - stress the inability of ironclad rules to deal with unforeseen shocks or changes in the structure of the economy. Therefore, the two authors have argued that inflation targeting can be viewed as "constrained discretion", rather than as a rigid policy rule. ${ }^{16}$

Another important debate in the academic circles is about the objectives of the monetary policy. In this context, intellectual developments have contributed to the fading reputation of strongly activist monetary policies that can be defined as policies whose purpose is to keep output and unemployment close to their "full employment" levels at all times.

Three such developments have been considered as influential: (1) Milton Friedman's monetarist critique, particularly his observation that monetary policy works only with " long and variable lags "; (2) the conclusion, that has been reached by Friedman and Edmund Phelps, that there is no long-run tradeoff between inflation and unemployment; and (3) the agreement regarding the potential importance of central bank credibility to the effectiveness of monetary policy. $\frac{17}{}$

In addition, some studies have shown that, in the long run, inflation - at least at double digit levels - is negatively correlated with economic growth (for example: Barro (1995) and Fischer (1995)). High inflation also leads to more variability in future inflation which can be costly for the economy. In the short run, however, there is a positive correlation between growth and inflation. If authorities have discretion to choose between multiple objectives of price stability and economic growth, there is an incentive to create "surprise" inflation, particularly in the runup to elections. This time-inconsistency problem leads to an inflationary policy bias.

Therefore, the inability of monetary policy to boost employment in the long run, the high costs of inflation, and the time inconsistency problem has resulted in the conclusion that the overriding, long run goal of monetary policy has to be price stability.

\footnotetext{
$\underline{16}$ For more details, refer to Bernanke and Mishkin (1997).

$\underline{17}$ Refer to Bernanke et al. (1999).
} 
In order to understand the importance of price stability as a prime objective in the inflation targeting framework, Meyer (2002) has mentioned that it is recognized that even if the relationship between money growth and inflation has weakened, perhaps because of financial innovations, central banks can achieve their inflation targets by adjusting their preferred instrument, typically some short-term interest rate. Hence, monetary policy still determines the rate of inflation in the long-run. While it is also well understood that supply shocks (such as abrupt changes in the price of energy or food unrelated to the overall balance between aggregate demand and supply) can result in short-run changes in inflation, such changes in inflation can persist only if central banks accommodate them.

Central banks therefore must accept full responsibility for inflation in the long run and have the tools to achieve price stability. While monetary policy can achieve a long-run inflation target, economic theory suggests that it cannot affect the level of output or its growth rate in the long-run, other than by maintaining low and stable inflation. Therefore, the objective of price stability can be assigned to monetary policymakers, but the objective of high and rising living standards can not be.

Moreover, the adoption of inflation targeting regime, has paved the way towards an intensive body of the literature that has tried to assess such a framework and to investigate its economic effects on inflation, output and interest rates (for instance: Bernanke and Mishkin (1997) have discussed the inflation targeting framework as a new strategy. They have concluded that this approach has a number of advantages, including more transparent and coherent policymaking, the increased accountability, and the greater attention to long-run considerations in day-to-day policy debates and decisions).

\subsection{The Relevant Literature Regarding the Assessment of the Impact of Inflation Targeting Framework on Macroeconomic Variables in Industrialized Countries:}

Inflation targeting as a framework for monetary policy has been first adopted by industrial countries like New Zealand, Canada, the United Kingdom and Sweden in the early 1990s. In most cases, the adoption of this framework is a response to difficulties in conducting monetary policy using an exchange rate peg or some monetary aggregate as an intermediate target. Masson et al. (1997) have highlighted those developments.

Therefore, since mid-1990s an extensive body of papers has tried to investigate the impact of the inflation-targeting framework on economic performance. In what follows, there is a review of those contributions. 
Mishkin and Posen (1997) have estimated a three-variable unrestricted Vector Autoregression (VAR) model of core inflation, Gross domestic Product (GDP) growth, and the central bank's overnight instrument interest rate from the second quarter of 1971 to the date of target adoption in four countries. The two authors have suggested that targeting inflation whether directly, as in New Zealand, Canada, and the United Kingdom, or as the basis for a monetary targeting regime, as in Germany - can be considered as a useful strategy for the conduct of monetary policy. Furthermore, they have mentioned that there is no evidence that inflation targeting can produce undesirable effects on the real economy in the long-run; instead, it more likely to improve the climate for economic growth.

Moreover, Honda (2000) has argued that there is no empirical evidence that inflation targeting has changed macroeconomic variables in the unrestricted VAR context using data for three inflation targeters: New Zealand, Canada, and the United Kingdom. He has calculated the standard Chow test statistics. The results have showed that there is no possibility to reject the null hypothesis of no structural change in all countries at the significance level of $5 \%$. Interestingly, Bernanke and Mihov (1998) have used a similar Chow test that also has failed to reject the no-change null hypothesis in a different context of a VAR model.

Alternatively, Johnson (2002) has assessed the effect of introducing inflation targets on expected inflation in eleven developed countries ${ }^{18}$. He has found strong evidence that the period after the announcement of inflation targets were associated with a large reduction in the level of expected inflation. This indicates for some degree a desirable impact of inflation targeting adoption.

In their paper, Ball and Sheridan (2005) have analyzed the impact of inflation targeting on economic performance in twenty members of the Organization for Economic Cooperation and

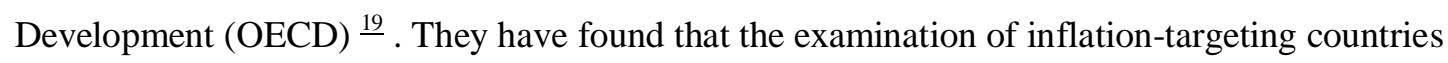
leads to the conclusion that their economic performance has improved on average between the period before targeting and the targeting period. For example, inflation has become more stable, and output growth has been stabilized. However, countries that have not adopted inflation

\footnotetext{
18 Johnson's paper has included five inflation targeting countries: Australia, Canada, New Zealand, Sweden and the United Kingdom as well as six non-targeting countries: France, Germany, Italy, the Netherlands, Japan and the United States.

19 Ball and Sheridan have used data for seven OECD countries that adopted inflation targeting in the early 1990s: Australia, Canada, Finland, Spain, Sweden, United .Kingdom, and New Zealand and thirteen that did not adopt it: Austria, Belgium, Denmark, France, Germany, Irelands, Italy, Japan, the Netherlands, Norway, Portugal, the United States and Switzerland. They excluded the emerging-market economies from their analysis. In addition, they excluded countries that lacked an independent currency before the Euro (Luxembourg) or had experienced annual inflation over 20\% since 1984 (such as: Greece, Iceland, and Turkey). See, Ball and Sheridan (2005, p.251).
} 
targeting also experienced improvements around the same times as targeters. This finding implies that better performance is attributed to something other than inflation targeting.

Angeriz and Arestis (2008) have applied an Intervention Analysis to Multivariate Structural Time Series Models to a number of OECD countries $\stackrel{20}{-}$. Their results demonstrate that both the inflation targeting and the non-targeting central banks have been successful in achieving low inflation rates.

The above-mentioned contribution in the literature shows a controversial opinion about the impact of inflation targeting on economic performance in industrialized countries. Hence, there is no final word on the remarkable advantage of inflation targeting in this context.

\subsection{The Relevant Literature Regarding the Assessment of the Impact of Inflation Targeting in Emerging Market Economies:-}

Mishkin (2000) has discussed the advantages and disadvantages of inflation targeting strategy in emerging-market countries $\stackrel{21}{ }$.He has mentioned that, although this strategy is not a panacea and may not be appropriate for many of those countries; it can be a highly useful monetary policy in a number of them. Mishkin has illustrated a critical issue for inflation targeting in emerging market countries that is the role of the exchange rate. Emerging market countries, including those engaging in inflation targeting, have rightfully been reluctant to adopt an attitude of "benign neglect" of exchange rate movements, partly because of the existence of a sizable stock of foreign currency or a high degree of (partial) dollarization.

Nonetheless, emerging market countries probably have gone too far, for too long, in the direction of limiting exchange rate flexibility, not only through the explicit use of exchange rate bands, but also through frequent intervention in the foreign exchange market. Responding too heavily and too frequently to movements in a "flexible" exchange rate runs the risk of transforming the exchange rate into a nominal anchor for monetary policy that takes precedence over the inflation target, at least in the eyes of the public. One possible way to avoid this problem is for inflation targeting central banks in emerging market countries to adopt a transparent policy of smoothing short-run exchange rate fluctuations

\footnotetext{
$\underline{20}$ Angeriz and Arestis have included in their sample only OECD countries: Australia, Canada, Finland, South Korea, New Zealand, Norway, Spain, Sweden, Switzerland, and the United Kingdom. The United States (US) and the Economic and Monetary Union (EMU), have been included as the control group as they do not pursue inflation targeting

${ }^{21}$ Mishkin has included transition countries in Eastern Europe and the former Soviet Union in the emerging market category.
} 
that helps mitigate potentially destabilizing effects of abrupt exchange rate changes while making it clear to the public that they will allow exchange rates to reach their marketdetermined level over longer horizons. $\underline{22}$

Furthermore, Minella et al. (2003) have argued that inflation targeting in emerging market economies has been a more challenging task than in developed economies. The conduct of monetary policy has to build credibility and reduce inflation rate levels, and simultaneously deal with a greater vulnerability to shocks.

In a similar point of view, Harjes and Ricci (2008, p. 3) have stated that:

"Several authors, including Calvo (2001) and Mishkin (2004) have pointed to the specific difficulties that emerging market economies may face in conducting inflation targeting. First, credibility issues may weaken the design of optimal macroeconomic policy in these countries, and may reduce the effectiveness of monetary policy. Second, weak institutions may lead to currency substitution or liability dollarization, or even fiscal dominance, largely reducing the capability of the monetary authorities to target inflation effectively. Third, large exchange rate and other external shocks complicate the conduct of monetary policy, by introducing substantial volatility".

In this context, Amato and Gerlach (2002) have assessed the experience of emerging market economies in the adoption of inflation targeting, they have pointed out two main conclusions. First, in most cases inflation targeting has been introduced successfully without the economy in question satisfying the preconditions that play such an important role in the current literature. Second, exchange rate objectives may play a relatively greater role in emerging market economies, primarily due to the financial structure of these economies. In particular, during disinflations, inflation targets have coexisted with exchange rate targets, and while there have been conflicts, central banks have typically interpreted the inflation objective as the overriding goal of policy and acted accordingly. As the transition to low inflation progressed, formal exchange rate bands are broadened and, more recently, relinquished.

On the other hand, some authors have concentrated their assessment on specific countries. For instance: Schmidt-Hebbel and Werner (2002) have reviewed the recent inflation targeting experiences of Brazil, Chile, and Mexico, by using descriptive statistics and estimating impulse responses of headline and core inflation to inflation target shocks, based on VAR model estimations for each country. In addition, they have compared the

\footnotetext{
$\underline{22}$ Refer to Mishkin (2000).
} 
three countries' performance under inflation targeting to the performance of a control group of eleven other inflation targeting economies. $\underline{23}$

They have indicated that the three countries started from very different initial conditions and adopted strikingly different approaches to introducing inflation targeting. Furthermore, the three countries have been successful in meeting inflation targets and attaining relatively low sacrifice ratios and output volatility levels after adopting inflation targeting.

Whereas, Roger and Stone (2005) have concluded that emerging market economies appear to have generally higher levels of inflation variability than industrial countries. On the other hand, the generally successful experience of emerging market countries with fullfledged inflation targeting shows that inflation targeting is a viable alternative to an exchange rate anchor given the right circumstances and policies.

Gonçalves and Salles (2008) have reproduced Ball and Sheridan's (2005) analysis using data for 36 developing economies, 13 of which have implemented the inflation targeting framework. ${ }^{24}$ Their results suggest that the choice of the inflation targeting regime proved beneficial for emerging economies. In particular, their findings are as follows: (i) the greater fall in inflation experienced by emerging market targeters can, to some extent, be attributed to the regime itself and not only to mean reversion; (ii) those choosing to inflation target have achieved a greater reduction in growth volatility than those opting for alternative monetary policy arrangements. Moreover, the claim that inflation targeting regimes hinder economic growth is clearly not sustained by the empirical evidence.

In sum, the literature so far suggests that the adoption of inflation targeting by emerging economies contributes towards the attainment of superior outcomes in terms of economic performance. The above discussion shows that the adoption of inflation targeting is an appropriate option to emerging market economies.

\footnotetext{
$\underline{23}$ Schmidt-Hebbel and Werner (2002) have mentioned that comparing the performance of Brazil, Chile and Mexico with that of the control group was demanding for those three countries because the control group comprises economies that, on average, were stable and performed well: Australia, Canada, Colombia, Finland, Israel, Korea, New Zealand, South Africa, Spain, Sweden, and the United Kingdom.

$\underline{24}$ The inflation targeters in the sample are Brazil, Chile, Colombia, Czech Republic, Hungary, Israel, Mexico, Peru, Philippines, Poland, South Africa, South Korea and Thailand. The group of non-targeters is comprised by Argentina, Bulgaria, China, Costa Rica, Côte d'Ivoire, Dominican Republic, Ecuador, Egypt, El Salvador, India, Indonesia, Lebanon, Malaysia, Morocco, Nigeria, Pakistan, Panama, Tunisia, Turkey, Uruguay, Venezuela, Singapore and Taiwan. See, Gonçalves and Salles (2008).
} 


\section{Overview of The Monetary Policy Performance in Brazil, Chile and South Africa:-}

This section illustrates the monetary policy adopted in the three countries that are in the core interest of this paper. The main aim of this section is to investigate the main reasons behind the move towards the announcement of inflation targeting regime.

\subsection{The Monetary Policy Performance in Brazil:-}

In Brazil, the monetary policy of the Real Plan $\underline{25}$ has been marked by the high priority placed on initially accomplishing and thereafter maintaining price stability. In July 1994, quarterly targets for the monetary aggregates have been introduced to build-up confidence that there will be no inflationary financing of the government deficit. In order to prevent the upturn in private spending (stemming from pent-up demand) from adversely affecting prices, credit expansion was initially constrained by the imposition of a 100\% marginal reserve requirement. Subsequently, restraints have been placed on various forms and maturities of credit operations. The swift growth of narrow monetary aggregates at the outset of the Real Plan has been mainly determined by the large increase in the transactions component of the demand for money, which in turn to the desired interest rate path.

The Real plan has successfully led to the reduction in inflation from above 2000 percent to 1.5 percent in 1998. However, the Brazilian government has not been as successful in implementing much needed fiscal reforms. Following concerns about the fiscal balance, the Real has come under speculative attack at the end of 1998 and collapsed in January 1999. As a consequence of strong pressures on foreign exchange reserves, the $\mathrm{BCB}$ has been forced to abandon the crawling peg to the dollar. ${ }^{26}$ After a brief attempt to conduct a controlled devaluation, the Real has been forced to float on January 15. Hence, the BCB has acknowledged the need to put in place a nominal anchor and introduced an inflation targeting regime on 21 June, 1999. ${ }^{27}$

\footnotetext{
$\underline{25}$ This plan has been introduced in 1994 and targeted mainly the Brazilian currency.

$\underline{26}$ Under this exchange rate regime, the currency is adjusted periodically in small amounts at a fixed rate or in response to changes in selective quantitative indicators, such as past inflation differentials vis-à-vis major trading partners, differentials between the inflation target and expected inflation in major trading partners. The rate of crawl can be set to adjust for measured inflation or other indicators (backward looking), or set at a preannounced fixed rate and/or below the projected inflation differentials (forward looking). Maintaining a crawling peg imposes constraints on monetary policy in a manner similar to a fixed peg system. Refer to: the International Monetary Fund (2006 (a)).

$\underline{27}$ Refer to Levin et al. (2004, p. 64) and Bogdanski et al. (2000, pp.7-8).
} 
It worth mentioning that before the adoption of inflation targeting regime, the $\mathrm{BCB}$ has never been granted formal instrument independence to conduct monetary policy. Moreover, even at the Bank, very few staff members knew what an inflation targeting framework was about. This coincides with the remark by Mishkin (2004); that the independence of Brazil's central bank and the commitment to price stability, however, have not been clearly achieved. Both are based on a presidential decree and confidence in a superb central bank president, but not on a more formal commitment based on legislation.

On the same date of the adoption of inflation targeting framework for the conduct of monetary policy, the President of Brazil has issued a decree instituting it.

The regime contains all the key elements of an inflation targeting strategy, namely; (1) the announcement of multi-year inflation targets with explicit numerical targets for the 12-month rate of inflation in the years 1999, 2000 and 2001, and a commitment to announce the targets for 2002 onwards two years in advance ; (2) assigning to the National Monetary Council the responsibility for setting the inflation targets and tolerance ranges based on a proposal by the Minister of Finance; (3) giving to the BCB full responsibility to implement the policies needed to attain the inflation targets; (4) establishing procedures to increase the central bank's accountability specifically, if the target range is breached, the central bank president would have to issue an open letter to the Minister of Finance explaining the causes of the deviation, the measures that will be taken to eliminate it, and the time it will take to get inflation back inside the tolerance range; and (5) taking actions to improve the transparency of monetary policy concretely. $\stackrel{28}{ }$

Afterwards, the National Monetary Council has issued a Resolution on June $30^{\text {th }}, 1999$ to define the price index used as well as the inflation targets. The Broad Consumer Price Index (IPCA) reported by the National Bureau of Geography and Statistics (IBGE) has been chosen for the purpose of gauging inflation targets. The targets have been announced at $8 \%$ for 1999 , $6 \%$ for 2000 and $4 \%$ for 2001 with tolerance intervals of $\pm 2 \%$ for each year.

The inflation targeting regime in Brazil has been subject to severe shocks due to a domestic energy crisis, adjustments in administered prices, and a depreciating exchange rate, which has been later exacerbated by pre-election uncertainty.

\footnotetext{
$\underline{28}$ The (BCB) was requested to issue a quarterly Inflation Report modelled after that produced by the Bank of England. Refer to Mishkin and Savastano (2001, p.440).
} 
The authorities have reacted with significant foreign exchange intervention to prevent vulnerabilities to further shocks resulted from tightening the monetary policy in October 2002, after that the Net International Reserves (NIR) has declined by US\$ 13 billion. ${ }^{29}$

As Minella et al. (2003) have showed, the inflation-targeting mechanism has played a key role in macroeconomic stabilization in Brazil. In spite of large inflationary shocks, the inflation rate has been maintained at a low level. Exchange rate depreciations in 2001 and 2002 have been considered as stress tests for the regime. In particular, in 2002, monetary policy has faced a confidence crisis in the future performance of the Brazilian economy and an increase in risk aversion in international markets.

Those negative consequences have been reflected by turmoil in the domestic financial market, by difficulties in public debt management and by a steep decrease of foreign credit flows, negatively affecting both inflation and the level of activity. This in turn has resulted in the non-fulfillment of the target of inflation rate as indicated by the measured rate of the change in the Broad Consumer Price Index (IPCA). This rate has reached $12.5 \%$ in 2002, above the upper limit of the tolerance interval of 2 percentage points above and below the $3.5 \%$ central target set for the year.

As of January 2004, inflation has appeared poised to drop back within the inflation targeting range. Twelve-month-ahead inflation expectations have dropped to 5.6 percent by December and monetary policy had loosened substantially, suggesting that the cycle of overshooting has ended. Other indicators have been positive, including a sharp drop in external debt spreads, a reduction in the debt to GDP ratio, and an expected recovery of growth.

The above improvement is evident in figure (1) where the net public debt to GDP ratio declined from 52\% in January 2004 to $40.4 \%$ in June 2008.

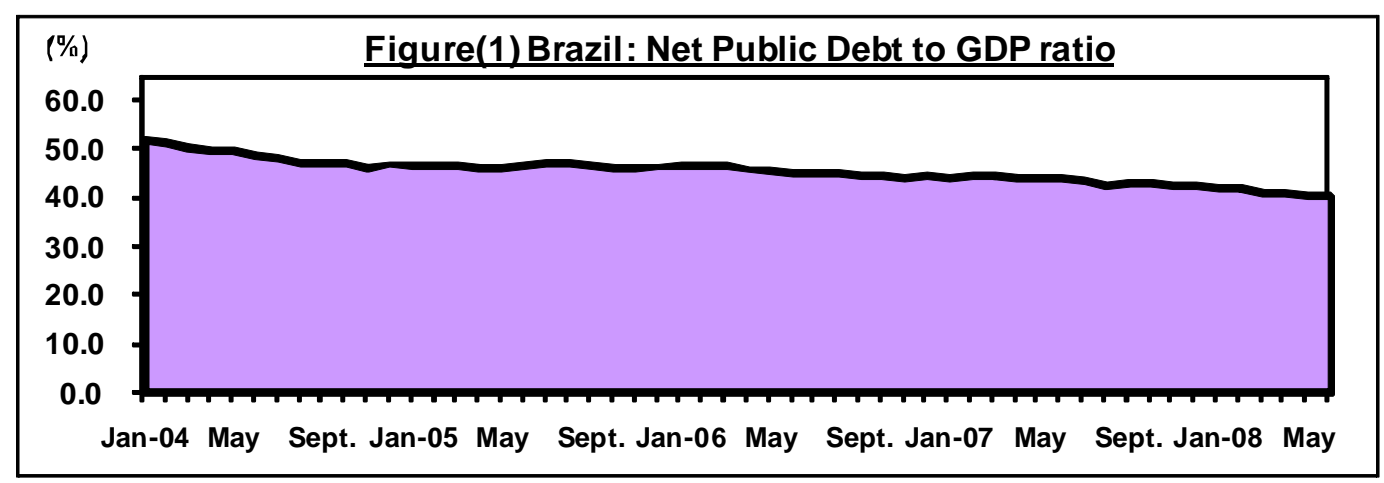

Source: The Brazilian Central Bank. Time series available at: http://www.bcb.gov.br/?NPDBREAKDOWN

\footnotetext{
$\underline{29}$ Refer to the International Monetary Fund (2006 (b), p.41).
} 
In addition, table (1) indicates an improvement in macroeconomic indicators in Brazil after the adoption of inflation targeting. The deficit in the current account has turned from a deficit of 18.4 billion of US\$ in 1995 into surplus of 4.2 billion of US\$ in 2003 and 1.7 billion of US\$ in 2007. Inflation rate has declined from $22.4 \%$ in 1995 to $4.5 \%$ in 2007. Economic growth has reached $5.4 \%$ in 2007 compared to $4.2 \%$ in 1995.

Table(1): Macroeconomic Indicators in Brazil 1995-2007

\begin{tabular}{|c|c|c|c|}
\hline Years & $\begin{array}{c}\text { Surplus or Deficit in the Current } \\
\text { Account } \\
\text { (Billion of US\$) }\end{array}$ & $\begin{array}{c}\text { Inflation rate } \\
(\%)^{*}\end{array}$ & $\begin{array}{c}\text { Annual rate of } \\
\text { Economic Growth } \\
(\%) * * *\end{array}$ \\
\hline 1995 & -18.4 & 22.4 & 4.2 \\
\hline 1996 & -23.5 & 9.6 & 2.2 \\
\hline 1997 & -30.5 & 5.2 & 3.4 \\
\hline 1998 & -33.4 & 1.5 & 0.0 \\
\hline 1999 & -25.3 & 8.9 & 0.3 \\
\hline 2000 & -24.2 & 6.0 & 4.3 \\
\hline 2001 & -23.2 & 7.7 & 1.3 \\
\hline 2002 & -7.6 & 12.5 & 2.7 \\
\hline 2003 & 4.2 & 9.3 & 1.1 \\
\hline 2004 & 11.7 & 7.6 & 5.7 \\
\hline 2005 & 14.0 & 5.7 & 3.2 \\
\hline 2006 & 13.6 & 3.1 & 3.8 \\
\hline 2007 & 1.7 & 4.5 & 5.4 \\
\hline
\end{tabular}

Source: The Brazilian Central Bank(BCB). Time series available at: http://www.bcb.gov.br/?TIMESERIESEN

Notes: * measured as a percentage change in the Broad Consumer Price Index (IPCA).

** Percentage change of Gross Domestic Product (GDP).

Investigating the Brazilian experience with inflation targeting regime shows that the inflation targets as well as the upper and lower limits have been modified many times during the period 1999-2007. The current target is to achieve $4.5 \%$ with tolerance intervals of $\pm 2 \%$ for each year. This target is aimed till 2009. $\frac{30}{3}$

$\underline{30}$ Refer to table (A-2) in the appendix that illustrates the Brazilian inflation targeting regime. 
The above discussion shows that the adoption of inflation targeting framework was a consequence to difficulties that the economy has faced and this framework helped to achieve confidence in the Brazilian economy and credibility of monetary policy.

\subsection{The Monetary Policy Performance in Chile:-}

After a decade of moderate but stubborn inflation, the recently independent Central Bank

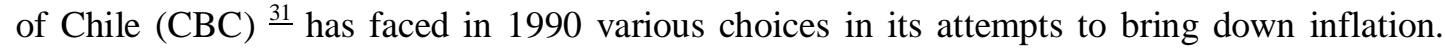
Chile's inflation history records two major stabilization programs based on a nominal exchange rate anchor: 1959-1962 and 1979-1982. Both programs failed badly - reducing the possibility of a credible using of exchange rate anchor for a third time to bring inflation down on a sustained basis. On the other hand, the use of monetary aggregates as an intermediate target would have been difficult in a country with developing financial markets and volatile demands for monetary aggregates. Therefore, the remaining choice for a monetary framework was inflation targeting.

Chile is considered as the second country in adopting inflation targeting in the world, setting its first annual target in September 1990 for the following year. Since then, Chile's Central Bank has used inflation targeting to bring inflation down from 27\% in 1990 to low, stationary levels that are consistent with the indefinite target range of $2-4 \%$ per year.

As part of the process of hardening the targets, in September 1994 the CBC has started to announce point targets rather than target ranges for its inflation objective for the following year. However, in 1999, the central bank explicitly has announced a multi-year target for inflation consisting of a target of $3.5 \%$ for the year 2000, and a longer term target of $2-4 \%$ for 2001 onwards.

The focus on the exchange rate has resulted in a serious policy mistake in 1998. In the aftermath of the Asian crisis and then the meltdown in Russia, the $\mathrm{CBC}$ has been reluctant to ease monetary policy and let the exchange rate depreciate in order to cushion the effects of a substantial negative term of trade shock. Instead, the central bank has raised interest rates sharply and narrowed its exchange rate band. As a result, the inflation target has been undershot and the economy entered a recession for the first time under the inflation targeting regime.

31 Before embarking on inflation targeting, Chile passed new central bank legislation in 1989 (that took effect in 1990), which gave independence to the central bank and mandated price stability as one of its primary objectives. See, Mishkin (2000, p.107).

- For the Chilean experience, refer to: Landerretche et al. (1999, pp 9-10), Schmidt - Hebbel and Tapia (2002, pp. 125-126), Levin et al. (2004, p.63), Betancour et al. (2008, p. 159). 
Not surprisingly given those outcomes, the central bank has been severely criticized. During 1999, the central bank has reversed course, eased monetary policy by lowering interest rates, and allowed the peso to depreciate.

A key feature of the Chilean experience has been the gradual approach to disinflation, which has produced low inflation without suffering excessively large output costs. Chile had an exchange rate band around a crawling peg until August 1999; it has since adopted a fully floating exchange rate regime. Inflation targeting in Chile has been generally successful in bringing down inflation, even though a strong fiscal position and a sound financial system played an important role in supporting this performance. Furthermore, in 1999-2000 the Bank has upgraded its monetary framework to full-fledged inflation targeting. This includes disposing of the exchange rate band by adopting a dirty float, developing the Bank's modelling and forecasting capability, and adopting a comprehensive communications strategy to enhance policy transparency and credibility. The latter comprises publication of the schedule and minutes of monetary policy meetings (the latter with a three-month lag) and a regular inflation report with inflation and growth projections.

As an assessment of the Chilean experience Céspedes and Soto (2006) have showed that the move to a full-fledged inflation-targeting framework was seen as the natural step after reaching the steady-state level of inflation and establishing sufficient credibility in monetary policy. It was triggered, in part, by the macroeconomic outcomes of the Asian crisis. GDP growth has declined significantly in 1998-99, while the annual inflation rate has dropped from 4.6 percent in 1998 to 2.3 percent in 1999 . These events have forced the monetary authority to substantially enhance its macroeconomic framework through the adoption of a free-floating exchange rate regime, the deepening of the foreign exchange derivatives market, and the total opening of the capital account.

Over the same period, the Chilean economy has gone through several important structural changes. The financial sector has deepened, and the degree of openness to external economic influences has increased, with unilateral tariff reductions and the signing of many free trade agreements, most notably with the United States and the European Union. The 1990s has proved to be the Chilean economy's best decade for growth in its history. Although growth has moderated in the present decade, it is still very high from both a historical and a regional perspective. Inflation has declined to levels comparable to those in the industrial economies, and the volatility of both output and inflation has fallen significantly. With these achievements, Chile can be considered a good example of what has been called the "great moderation", a phenomenon seen in many countries in recent decades in which not only the level of inflation 
but also the volatility of both inflation and output has declined sharply. Figure (2) indicates the "great moderation" phenomenon as there is a decline in inflation from 17\% in 1989 to $4.4 \%$ in 2007. This implies an advantage of the adoption of inflation targeting regime that enabled the monetary authority to capture inflation. In addition, there is a decline in the annual economic growth from $24.3 \%$ in 1989 to $10.3 \%$ in 2007.

\section{Figure (2): Annual Change in the Consumer Price Index and Annual}

\section{Economic Growth in Chile}

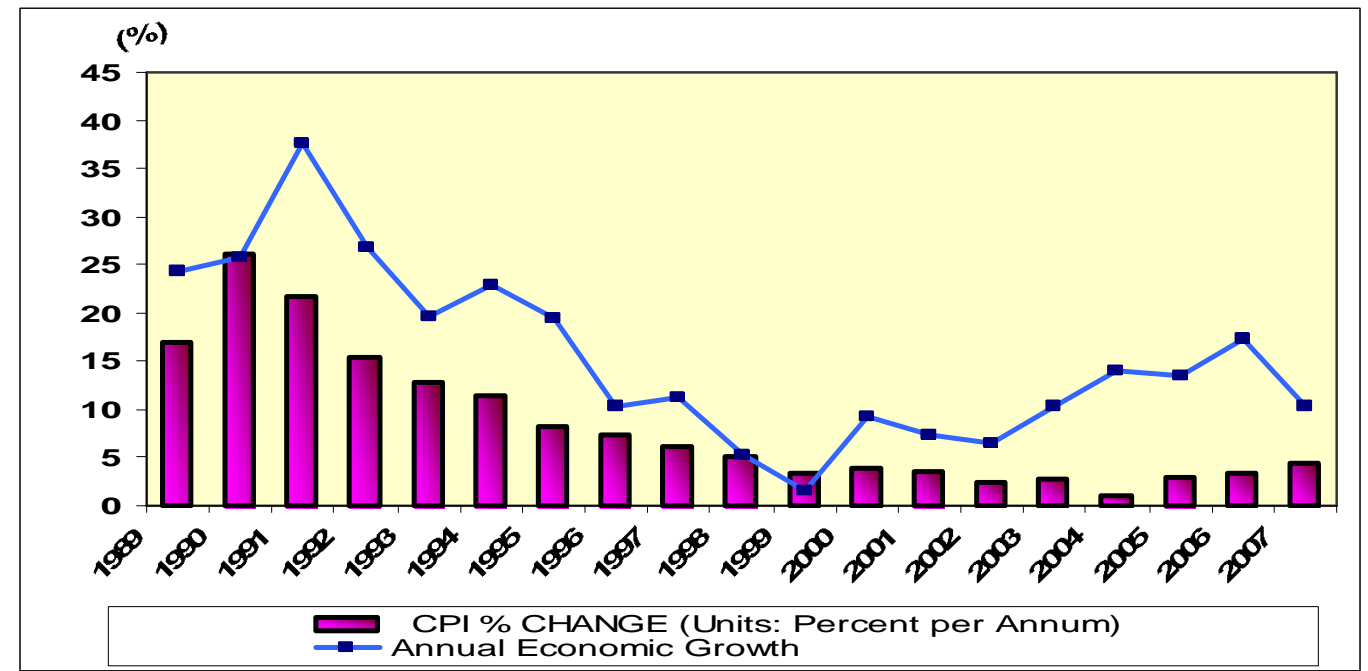

Source: International Monetary Fund, International Finance Statistics Database.

* Annual Economic Growth is calculated as percentage change of Gross Domestic Product.

\subsection{The Monetary Policy Performance in South Africa:-}

The monetary policy frameworks in South Africa comprise five broad frameworks. First, there was a liquid asset ratio-based system with quantitative controls over interest rates and credit up to the early 1980s. In the liquid asset ratio-based system the interest rate played a minor part as a corrective instrument whereas the main form of monetary control was achieved through liquid asset requirements. Second, the period from 1981 to 1985 represents a transition period. Third, explicit monetary growth targets and later guidelines for $\mathrm{M}_{3}$ are announced annually from 1986 to 1998 . The pre-announced monetary targets have to be achieved indirectly by adjusting interest rates. The short-term interest rate has become the main monetary policy instrument as the Reserve Bank's discount rate has been employed to influence the cost of overnight collateralized lending and hence market interest rates. In order to reduce demand for bank credit, Bank rate has increased. Financial liberalization and other structural developments in the 1990s have resulted in a changed relationship between growth in money 
supply, output and prices, and significantly reduced the usefulness of money supply targets. These targets have been subsequently formally supplemented by a broader set of indicators that included the exchange rate, asset prices, the output gap, the balance of payments, wage settlements, total credit extension and the fiscal stance. Policy increasingly moved towards greater transparency, aimed at achieving greater credibility and a more pronounced effect on inflation expectations. Fourth, from March 1998 the $\mathrm{M}_{3}$ growth guidelines have been set for a three-year period and an informal inflation target of 1 to 5 per cent was set for the first time. The new monetary system has effectively rationed the amount of liquidity. $\underline{32}$

Finally, in February 2000, the "Formal Inflation Targeting" ${ }^{33}$ has been adopted in South Africa as the monetary policy framework. Before this announcement "Informal Inflation Targeting" $\underline{34}$ has already applied by the South African Reserve Bank (SARB). Considerable emphasis was placed on the attainment of price stability, but the period over which this would be achieved was not specified. At first, the framework also differed from formal inflation targeting because an intermediate target, the growth in money supply, anchored monetary policy decisions. Later, towards the end of the 1990s, the Reserve Bank moved to "eclectic" ${ }^{35}$ or "pragmatic" inflation targeting. In this framework, developments in the monetary aggregates have been regarded as vital elements in the inflation process, but the Bank closely monitored developments in other financial and real indicators in reaching a decision on the appropriate level of short-term interest rates.

South Africa has adopted the inflation targeting framework; at a time when the country's inflation performance has been continuing to improve (falling to 5.2 percent in 1999 from 8.6 percent in 1997 and 6.9 percent in 1998). The inflation objective expressed in terms of an adjusted inflation rate, the headline consumer price index excluding mortgage interest costs.

The government announced the first inflation target after consultations with the South African Reserve Bank (SARB) and the framework initially included an escape clause for major unforeseen events outside central bank control. The target was an annual average inflation rate

\footnotetext{
$\underline{32}$ Refer to Casteleijn (2001, pp. 4-5).

$\underline{33}$ Most of the articles that tackled the experience of South Africa refer to the announcement of Inflation Targeting regime as an implementation of the "Full-Fledged Inflation Targeting Framework (FFIT)"; some other papers refer to such an announcement as the "Formal Inflation Targeting". However, I believe that both refer to the same framework where there is an explicit inflation target and the Reserve Bank of South Africa is committed to achieve it during a specific period.

$\underline{34}$ This implies that the Reserve Bank of South Africa had an informal goal of maintaining inflation at a level that would be more or less in line with the average inflation rate in South Africa's major trading partners and international competitors. See, Agénor (2000, p.46).

${ }^{35}$ This coincides with the "Implicit Price Stability Anchor (IPSA)" regime mentioned (in section 2) of this paper due to the classification by Carare and Stone (2006).
} 
of the Consumer Price Index (CPI) excluding mortgage costs (CPIX). A 3-6 percent target has been announced for 2002 and 2003, and a 3-5 percent target for 2004 and 2005. No explicit target has been decided for the transition period between February 2000 and 2002. The target range reflects the uncertainties about the inflation process and the required discretion in monetary policy. The fiscal and external positions of South Africa have improved since the adoption of inflation targeting.

This medium-term target has been agreed upon in view of estimated lags between monetary policy decisions and their impact on inflation: changes in interest rates in South Africa have been estimated to take from 18 to 24 months to affect inflation. The relatively large width of the band has been chosen to account for the fact that the targeted price index includes a large number of volatile items, whose movements are beyond the control of the Reserve Bank. Attempts to improve transparency have taken the form of public explanations of the monetary policy stance following meetings of the Monetary Policy Committee of the Reserve Bank, the creation of a Monetary Policy Forum that meets twice a year (in May and November), and the publication of a semi-annual Monetary Policy Review (twice a year beginning in 2001).

The following table shows the developments in the monetary policy in South Africa since 1960s till present.

Table (2): The Evolution of South Africa's Monetary Policy Framework

\begin{tabular}{|l|l|}
\hline Years & Monetary Policy Regime \\
\hline $1960-1981$ & $\begin{array}{l}\text { Liquid asset ratio-based system with quantitative controls on } \\
\text { interest rates and credit }\end{array}$ \\
\hline $1981-1985$ & Mixed system during transition \\
\hline $1986-1998$ & $\begin{array}{l}\text { Cost of cash reserves-based system with pre-announced } \\
\text { monetary targets }\left(\mathrm{M}_{3}\right)\end{array}$ \\
\hline $1998-1999$ & $\begin{array}{l}\text { Daily tenders of liquidity through repurchase transactions (repo } \\
\text { system), plus pre-announced }\left(\mathrm{M}_{3}\right) \text { targets and targets for core } \\
\text { inflation }\end{array}$ \\
\hline 2000- present & Formal inflation targeting \\
\hline \multicolumn{2}{|l}{ Source: Casteleijn (2001, p.5). }
\end{tabular}

The South African Reserve Bank's key operational variable within its monetary policy framework is the level of short-term interest rates. South African monetary authorities therefore largely determine the level of short-term interest rates. The Bank is able to influence these rates through its control over the bank repurchase (or repo) rate. To make the repo rate effective, the Reserve Bank intervenes in the money market to create a shortage, that is, it drains excess liquidity. By ensuring that a money market shortage exists at all times, it means that 
commercial banks are always indebted to the Reserve Bank and within its financial grip. The monetary policy committee determines the repo rate, which represents the marginal cost of money for the banks.

\section{Figure(3): Monetary Policy Transmission Mechanism in South Africa}

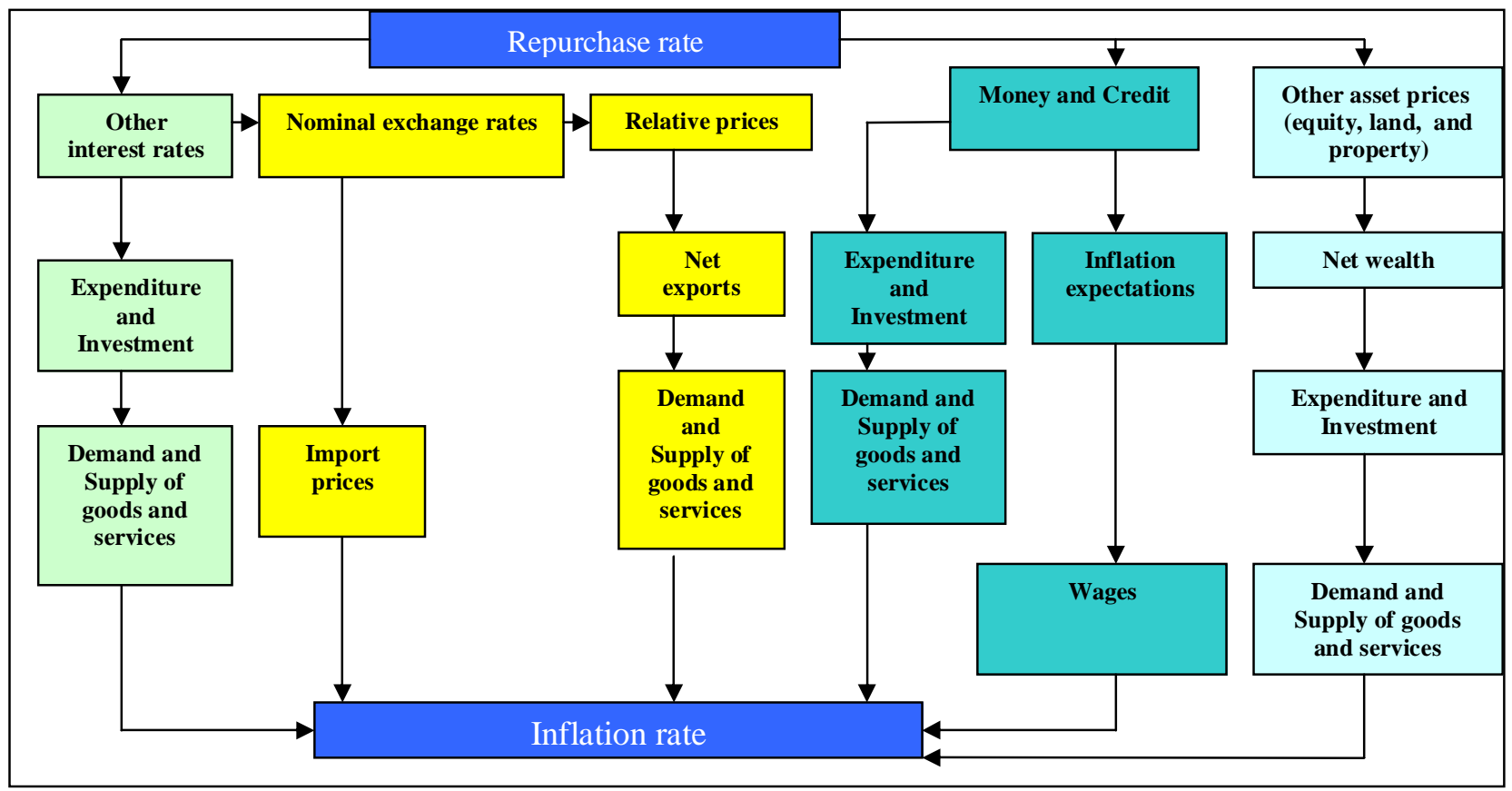

Source: Smal and de Jager (2001, p.5).

When the Reserve Bank decides to influence the change in the repo rate, it sets in motion a series of economic events. Economists refer to this chain of developments as the "transmission mechanism of monetary policy". The main links in the transmission mechanism of monetary policy, depicted in the flow chart in figure (3), which can be briefly described as follows: the main instrument for monetary policy is the repo rate. This rate has direct effects on other variables in the economy, such as other interest rates, the exchange rate, money and credit, other asset prices and decisions on spending and investment. Therefore, changes in the repo rate affect the demand for and supply of goods and services. The pressure of demand relative to the supply capacity of the economy is a key factor influencing domestic inflationary pressures. Inflation is, amongst others, the result of pressures originating in the labour market and/or the market for goods and services as well because of imported inflation, which is influenced by exchange rate movements. 
Macroeconomic polices in South Africa have been impressive and currency substitution or liability dollarization were virtually absent. In particular, the sharp depreciation of the rand in 2001-02 has proven that there was certainly no "fear of floating" emerging market countries, South Africa implementation of the inflation targeting strategy is often challenged by large exogenous—often external—shocks. In the typical environment in which many emerging markets operate-small open economies well integrated within a globalized world - an essential tool for policymaking lies in a coherent forward-looking framework for assessing the effect of external and domestic shocks on inflation, and for gauging the appropriate policy response.

Due to those shocks, the inflation target has been overshot by an average of 3.7 percent during the period of April 2002 to April 2003 in the wake of a sharp depreciation of the rand. The overshooting peaked at 5.3 percent in October-November 2002. The overshooting has been realized by the 35 percent depreciation of the rand during the last four months of 2001, an increase in world oil and grain prices, and uncertainties regarding the loosening of exchange controls. The (SARB) has attributed the currency depreciation to regional political instability and an increase in international investor risk aversion with respect to emerging market countries. There have been no major changes to the framework in response to the overshooting. In October 2002, the Minister of Finance has announced that the 3-5 percent target for 2004 would be adjusted upward slightly to 3-6 percent. Similarly, in February 2003 the Minister has announced that the 3-5 percent target for 2005 can also be adjusted to 3-6 percent.

The following figure illustrates the evolution of the percentage change in the consumer price index during the inflation targeting period. It shows the two main indices the total (CPI) and the (CPIX). As indicated from the figure the (CPIX) reflects the inflationary pressures that the economy might face - due to external or domestic shocks- better than the overall (CPI). The percentage change in the (CPI) reached $10.2 \%$ in the first quarter of 2008 compared with $13.3 \%$ in the second quarter of 2002. Whereas, the (CPIX) reached almost $22 \%$ compared with $14.5 \%$.

This indicates the importance of inflation targeting regime to mitigate the inflationary pressures that the South African Economy is more likely to face during the coming period that can be expected from analyzing figure 4 .

\footnotetext{
$\underline{36}$ This expression is used in the literature to indicate the fear of emerging market economies to move from pegged exchange rate regimes to free floating. Indeed "fear of floating" is only part of more general "fear of large exchange rate swings", in emerging market economies. This reluctance to allow the exchange rate to adjust significantly and rapidly is also manifest in the many episodes during which central banks go to great length to avoid a devaluation. For more details refer to Calvo and Reinhart (2000, p.2).
} 


\section{Figure (4): Percentage Change in the Consumer Price Index in South Africa}

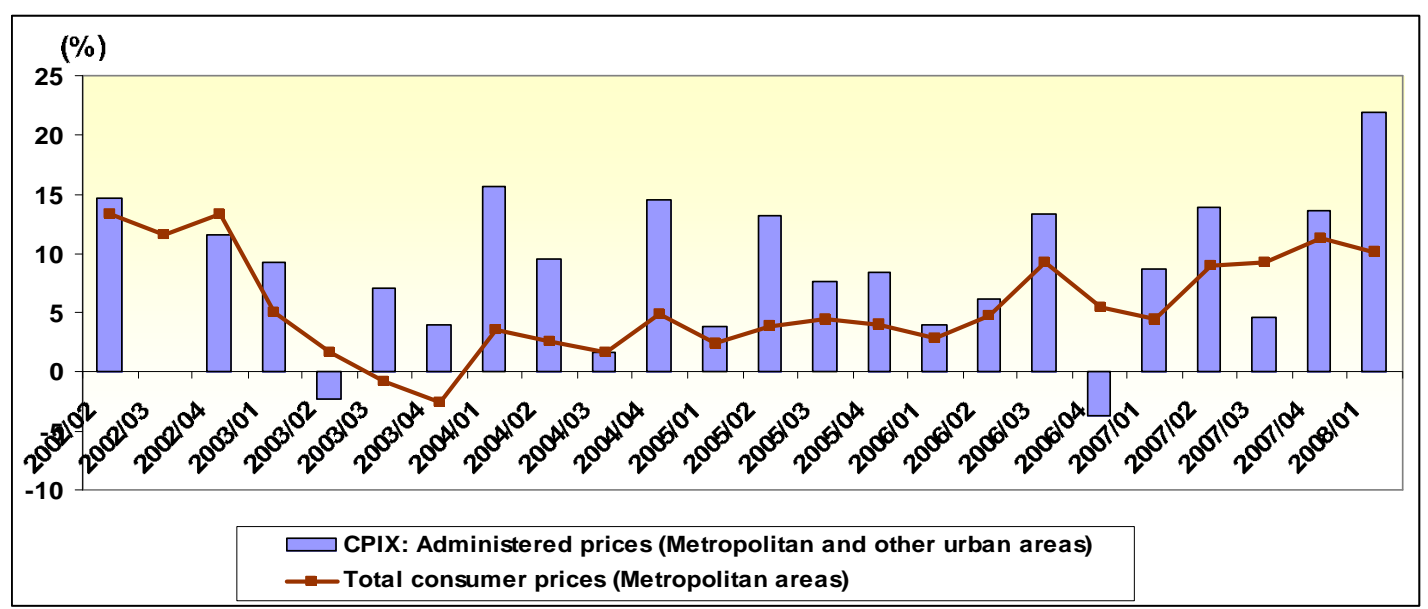

Source: South African Reserve Bank. Database available at: http://www.reservebank.co.za/

* The two series are seasonally adjusted at annual rate.

After this overview of the monetary policy frameworks in Brazil, Chile and South Africa, it is obvious to end up with the following remark that the examples of Chile and Brazil illustrate that inflation targeting is indeed feasible in emerging market economies, despite their more complicated political and economic environment. Inflation targeting has been able to provide a strong nominal anchor that can keep inflation expectations in check. However, this requires not only a focus on good communication and transparency by the central bank, but also supportive policies to develop strong fiscal, financial and monetary institutions. The Brazilian case suggests that these policies do not have to be fully in place when inflation targeting is adopted for it to produce good macroeconomic outcomes, but it is important to have a strong commitment to develop these institutions and continuing vigilance that fiscal, financial and monetary institutions will continue to be strengthened.

This coincides with the views of Mishkin and Savastano (2001, p. 441) who have stated that:

"Brazil has shown the way, indicating that an inflation targeting regime, with a high degree of transparency and accountability can indeed be implemented quickly"

Furthermore, the success of the Chilean experience suggests that inflation targeting can be used to promote gradual disinflation, even when inflation starts from double digit levels, and that the gradual hardening of targets as inflation falls is an appropriate strategy to deal with the controllability problems when inflation is initially high. Indeed, this strategy has been used by Chile as well as many industrialized countries that adopted inflation targeting. $\frac{37}{7}$

\footnotetext{
${ }^{37}$ See, Mishkin and Savastano (2001, p.435) and Bernanke et al. (1999).
} 
The following table provides illustration of the inflation targeting framework in Brazil, Chile and South Africa.

\section{Table(3): Summary of Inflation Targeting Frameworks}

\begin{tabular}{|c|c|c|c|}
\hline Country & Brazil & Chile & South Africa \\
\hline Date of Announcement & June 1999 & September 1990 & February 2000 \\
\hline Current Inflation Target & $4.5 \%$ & $2-4 \%$ & $3-6 \%$ \\
\hline Inflation Report & \multicolumn{3}{|c|}{ yes } \\
\hline Target Announcement & $\begin{array}{c}\text { Set by National } \\
\text { Monetary Council } \\
\text { composed by finance } \\
\text { minister, planning } \\
\text { minister and Central } \\
\text { Bank president }\end{array}$ & $\begin{array}{l}\text { Central bank of Chile in } \\
\text { consultation with the } \\
\text { government }\end{array}$ & $\begin{array}{l}\text { the government after } \\
\text { consultations with the } \\
\text { (SARB) }\end{array}$ \\
\hline $\begin{array}{l}\text { Monetary Policy } \\
\text { Objective }\end{array}$ & $\begin{array}{l}\text { Price stability, sound } \\
\text { financial system }\end{array}$ & $\begin{array}{l}\text { Price stability, functioning } \\
\text { payment system }\end{array}$ & $\begin{array}{c}\text { Price stability } \\
\text { sound financial system }\end{array}$ \\
\hline Other feature & $\begin{array}{l}\text { Letter from } \\
\text { The governor to the } \\
\text { minister of finance if } \\
\text { the target has been } \\
\text { breached }\end{array}$ & $\begin{array}{l}\text { The (CBC)'s Press releases of } \\
\text { its monthly monetary policy } \\
\text { meeting provide explanation } \\
\text { of unforeseen events }\end{array}$ & $\begin{array}{l}\text { the framework included } \\
\text { an escape clause for } \\
\text { major unforeseen } \\
\text { events outside central } \\
\text { bank control }\end{array}$ \\
\hline Inflation Measure & $\begin{array}{l}\text { Broad consumer } \\
\text { price index } \\
\text { (IPCA) }\end{array}$ & $\begin{array}{l}\text { The underlying CPI (the total } \\
\text { index excluding fruits, } \\
\text { vegetables, and fuels) } \\
\text { maintained by the National } \\
\text { Statistics Bureau (INE). }\end{array}$ & $\begin{array}{c}\text { Core CPI } \\
\text { excluding raw food and } \\
\text { energy prices }\end{array}$ \\
\hline Operating target & $\begin{array}{l}\text { Overnight interbank } \\
\text { rate (SELIC) }\end{array}$ & Real Overnight interbank rate & The repo rate \\
\hline Instrument & & arket operations & \\
\hline
\end{tabular}

Source: Levin et al. (2004, pp. 68-69).

* I have updated the information in accordance to the information provided in the website of the Brazilian Central Bank, the Central Bank of Chile and the South African Reserve Bank.

As a final word, from my point of view, the South African experience provides a good example for a transition period from informal to formal inflation targeting which could be suitable for any emerging market economy that might be suffering from high rates of inflation but still in doubt of the ability of inflation targeting framework in curbing inflation. Therefore, by practicing such transition period it might improve the credibility of its monetary policy and be confident to announce the adoption of full-fledged inflation targeting regime.

In conclusion, it is not necessarily, for the adoption of inflation targeting regime by the emerging market economies that all the perquisites are fulfilled and the above experiences reflects the positive impact of this framework. 


\section{The Empirical Model: A Background}

Bagliano and Favero (1998) have pointed out that the Vector Auto-regression (VAR) analyses of the monetary transmission mechanism started to develop because of the failure of the traditional Cowles Commission models. This failure can be regarded as a result of two demolishing theoretical critiques introduced by Lucas and Sims. On one hand, the Lucas (1976) critique is related to structural models when the coefficient describing the impact of monetary policy on the macroeconomic variables of interest depend on the monetary policy regimes; in this case; no model estimated under a specific regime can be used to simulate the effects of a different monetary policy regime. On the other hand, the Sims (1980) critique attacks identification from a different perspective. Sims showed that the restrictions needed to support exogeneity in structural Cowles Commission-type models $\stackrel{38}{2}$ are 'incredible' in an environment where agents optimize intertemporally.

In this context, Faust et al. (2004) have mentioned that the seminal paper of Sims (1980) paved the way towards much attention to be devoted to studying the effects of monetary policy on macroeconomic variables using a vector Auto-regression (VAR). This approach relies on making identifying assumptions relating structural shocks to the reduced form errors of the VAR. While, many identification approaches have been proposed for identifying VARs, the most often adopted approach is applying short-run restrictions. These specify that some structural shock has no contemporaneous effect on one or more variables. Faust et al. (2004) have provided an example for short-run scheme where it may be assumed that monetary policy has no contemporaneous effect on output and prices. Such identifying assumptions had been used by Sims (1980) and in many other papers in the VAR literature, including Christiano et al. (1996, 1999), Bernanke and Blinder (1992) and Bernanke and Mihov (1998). Not only shortrun restrictions can be used in the estimated VAR, long-run approaches may be also used. An example of such type of restrictions is the one that reflects the neutrality or super neutrality arguments about the effects of monetary policy on real variables. (e.g. King and Watson (1997) make the assumption that monetary policy shocks have no long-run effect on output, and show

$\underline{38}$ Christ (1994, pp.47-49) has illustrated that in most of the Cowles theoretical work, the assumptions included the following: (a) Economic behavior is governed by simultaneous equations, (b) The equations of the model are linear in systematic variables and disturbances, (c) The systematic variables are observable, without error, (d) Variables change at discrete time intervals, such as yearly, or quarterly, or monthly, rather than continuously, (e) It is known which variables are exogenous, and which are predetermined, (f) The determinant of the coefficients of the jointly dependent variables is not zero, so that the reduced form exists, (g) The predetermined variables are linearly independent, so that their moment matrix can be inverted, (h) The structural equations are identified by a priori restrictions on their parameters, (i) The disturbances are normally distributed random variables with zero means and finite and constant variances and covariances are serially independent, and (k)The equation system is dynamically stable. 
that this long-run neutrality condition allows the identification of a very simple VAR). Bernanke (1996) and Sims (1998) have argued that while extant studies of the effects of monetary policy in a VAR differ greatly in their identifying assumptions and in the choice of the variables in the system, these studies nonetheless tend to agree on the qualitative effect of monetary policy shocks on macroeconomic variables and, in particular, to agree that monetary policy shocks account for a small portion of the forecast error variance of output. For example, Christiano et al. $(1996,1999)$ have obtained this conclusion in the recursive identification.

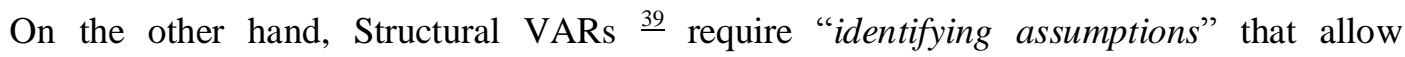
correlations to be interpreted causally. These identifying assumptions can involve the entire (VAR), so that all of the causal links in the model are spelled out, or just a single equation, so that only a specific causal link is identified. This produces instrumental variables that permit the contemporaneous links to be estimated using instrumental variables regression. $\stackrel{40}{40}$

In addition, in Structural VAR modeling it is common that just-identified models are considered. In other words, only as few restrictions are imposed as are necessary for obtaining unique impulse responses. If at some stages of the analysis it turns out that further restrictions are compatible with the data, it is also possible to impose them.

In this empirical section of the paper both VAR and Structural VAR approaches are used due to the importance of the remark by Elbourne and de Haan (2005) who have argued that the SVAR approach is better suited to small open economies than the Cholesky decomposition from VAR, because it can capture more of the salient features of the economies. Furthermore, they argued that VARs estimated over different policy regimes are misspecified and yield unreliable results. This motivated the paper to estimate Structural VARs for the periods of interest (i.e the pre-inflation targeting and the adoption periods) for three countries Brazil, Chile and South Africa.

\subsection{Estimation Approaches: Theoretical Framework:-}

A reduced-form VAR, as proposed by Sims (1980), is a regression of some vector of variables $\mathrm{Y}_{\mathrm{t}}$ on lags of this vector. Formally, the reduced-form VAR is a system of equations that can be written in matrix form as:

$$
Y_{t}=\alpha+A_{1} Y_{t-1}+\ldots+A_{k} Y_{t-k}+u_{t}
$$

\footnotetext{
$\underline{39}$ The Structural VAR approach is widely implemented in many econometric software packages like: Eviews.

${ }^{40}$ See, Stock and Watson (2001, p. 103).
} 
Where $\alpha$ is a vector of constants, $\mathrm{A}_{1}, \ldots \ldots \ldots, \mathrm{A}_{\mathrm{k}}$ are matrices of coefficients, and $\mathrm{u}_{\mathrm{t}}$ is a vector of innovations, that is, serially uncorrelated disturbances that have zero mean and a variance-covariance matrix $E\left(u_{t} u_{t}^{\prime}\right)=\sum_{u}$. The evolution of the vector $\mathrm{Y}_{\mathrm{t}}$, which contains the macroeconomic variables whose behavior we seek to understand, depends both on unexpected disturbances, $\mathrm{u}_{\mathrm{t}}$, and on a systematic component, $\alpha+A_{1} Y_{t-1}+\ldots+A_{k} Y_{t-k}$, that determines how the shocks are propagated to the rest of the economy. The estimates of , $\alpha$, $\mathrm{A}_{1}, \ldots \ldots \ldots, \mathrm{A}_{\mathrm{k}}$, are obtained by applying ordinary least squares (OLS) to each part of equation (1) separately, and the estimate of $\sum_{u}$ is given by the sample covariance matrix of the OLS residuals. Based on the estimated reduced-form VAR for different samples, it is possible to determine whether the variance-covariance matrix $\sum_{u}$ of the shocks and the systematic component-that is, the propagation mechanism-have changed over time. Through counterfactual experiments, it is possible to determine whether the observed reduced volatility in the main variables of interest has been due mainly to a change in the shocks or in the propagation mechanism. $\stackrel{41}{ }$

Also, I used Structural Vector Auto-regression (SVAR) estimation. The reason behind that is Elbourne and de Haan (2005) who argued that the SVAR model as proposed by Kim and Roubini (2000) yields much better results than a VAR with the same variables but using the commonly used Cholesky decomposition.

Therefore, following Kim and Roubini (2000, pp. 565-566), the economy is described by a structural form equation:-

$\mathrm{G}(\mathrm{L}) \mathrm{y}_{\mathrm{t}}=\mathrm{e}_{\mathrm{t}}$

Where $\mathrm{G}(\mathrm{L})$ is a matrix polynomial in the lag operator $\mathrm{L}, \mathrm{y}_{\mathrm{t}}$ is an $n \times 1$ data vector, and $\mathrm{e}_{\mathrm{t}}$ is an $n \times 1$ structural disturbances vector. $e_{t}$ is serially uncorrelated and $\operatorname{Var}\left(e_{t}\right)=\Lambda$ and $\Lambda$ is a diagonal matrix where diagonal elements are the variances of structural disturbances, therefore, structural disturbances are assumed to be mutually uncorrelated.

A reduced form equation (VAR) can be estimated:

$\mathrm{y}_{\mathrm{t}}=\mathrm{B}(\mathrm{L}) \mathrm{y}_{\mathrm{t}}+\mathrm{u}_{\mathrm{t}}$

Where $\mathrm{B}(\mathrm{L})$ is a matrix polynomial (without the constant term) in lag operator $\mathrm{L}$ and $\operatorname{var}\left(\mathrm{u}_{\mathrm{t}}\right)=\sum$.

$\underline{41}$ Boivin and Giannoni (2002, p. 98). 
There are several ways of recovering the parameters in the structural form equations from the estimated parameters in the reduced form equation. Some methods give restrictions on only contemporaneous structural parameters. A popular and convenient method is to orthogonalize reduced form disturbance by Cholesky decomposition (as in Sims (1980) among others). However, in this approach to identification, it is possible to assume only a recursive structure, that is, a Wold-causal chain. Blanchard and Watson (1986), Bernanke (1986), and Sims (1986) suggest a generalized method (Structural VAR) in which non-recursive structures are allowed while still giving restrictions only on contemporaneous structural parameters.

Hence, let $G_{0}$ be the coefficient matrix (non-singular) on $\mathrm{L}^{0}$ in $G(\mathrm{~L})$, that is, the contemporaneous coefficient matrix in the structural form, and let $G^{0}(\mathrm{~L})$ be the coefficient matrix in $G(\mathrm{~L})$ without contemporaneous coefficient $G_{0}$. That is,

$G(L)=G_{0+} G^{0}(\mathrm{~L})$

Then, the parameters in the structural form equation and those in the reduced form equation are related by

$B(\mathrm{~L})=-G_{0}^{-1} G^{o}(L)$

In addition, the structural disturbances and the reduced form residuals are related by $e_{t}=\mathrm{G}_{0} \mathrm{u}_{t}$, which implies

$$
\sum=G_{0}^{-1} \Lambda G_{0}^{-1^{\prime}}
$$

Maximum likelihood estimates of $\Lambda$ and $G_{0}$ can be obtained only through sample estimates of $\sum$. The right-hand side of equation (6) has $n \times(n+1)$ free parameters to be estimated. Since $\sum$ contains $n \times(n+1) / 2$ parameters, there is a need of at least $n \times(n+1) / 2$ restrictions. By normalizing $n$ diagonal elements of $G_{0}$ to 1 's, there will be a need of at least $n \times(n-1) / 2$ restrictions on $G_{0}$ to achieve identification. In the VAR modeling with Cholesky decomposition, $G_{0}$ is assumed to be triangular. However, in the SVAR approach $G_{0}$ can be any structure as long as it has enough restrictions.

In this context, Buckle et al. (2002) have mentioned that there are several ways of specifying the restrictions to achieve identification of the structural parameters. One procedure for determining appropriate restrictions to identify a SVAR is to use the restrictions that are implied from a fully specified macroeconomic model. For example: Blanchard and Watson (1986), have used theory to incorporate short-run restrictions; Shapiro and Watson (1988) and Blanchard and Quah (1989), have used theory to justify the inclusion of long-run restrictions, and Gali (1992), has used theory to justify both short-run and long-run restrictions. Moreover, Garratt, Lee, Pesaran and Shin (1998); Huh (1999) and Buckle, Kim and Tam (2001) have followed this approach. The alternative and more common approach is to choose the set of 
variables and identification restrictions that are broadly consistent with the preferred theory and prior empirical research. The metric used to evaluate the appropriateness of the variables and restrictions is whether the behaviour of the dynamic responses of the model is consistent with the preferred theoretical view of the expected response. Recent attempts to identify monetary policy effects in small open economies by Kim and Roubini (2000) and Brischetto and Voss (1999) are some of the many examples of this second approach.

It worth mentioning that, this paper followed the second approach in imposing short-term restrictions for the purpose of SVARs estimations.

On the other hand, another simple statistic- namely, the Likelihood Ratio (LR) statistic- has been used in order to provide a test for structural changes due to the adoption of inflation targeting framework in Brazil, Chile and South Africa. Following Hamilton (1994, p. 297) the $\log (\mathrm{LR})$ statistic is:

$$
\begin{aligned}
2\left(L_{1}^{*}-L_{0}^{*}\right) & =2\left\{(T / 2) \log \left|\hat{\Omega}_{1}^{-1}\right|-(T / 2) \log \left|\hat{\Omega}_{0}^{-1}\right|\right\} \\
& =T \log \left(1 / \hat{\Omega}_{1} \mid\right)-T \log \left(1 /\left|\hat{\Omega}_{0}\right|\right) \\
& =-T \log \left|\hat{\Omega}_{1}\right|+T \log \left|\hat{\Omega_{0}}\right| \\
& =T\left\{\log \left|\hat{\Omega}_{0}\right|-\log \left|\hat{\Omega}_{1}\right|\right\}
\end{aligned}
$$

Where: $L_{1}^{*}$ and $L_{0}^{*}$ are the maximum values for the log likelihood obtained from the unrestricted and restricted VARs, respectively. $\hat{\Omega}_{1}$ and $\hat{\Omega}_{0}$ are the variance- covariance matrices of residuals obtained from unrestricted and restricted VARs. Whereas, $\mathrm{T}$ is the total number of observations. Under the null hypothesis, this test asymptotically has a $X^{2}$ distribution with degrees of freedom equal to the number of restrictions imposed under $\mathrm{H}_{0}$. Hence, $\mathrm{H}_{0}$ imposes $n^{2}\left(p_{1}-p_{2}\right)$. Where $(n)$ is the number of variables used in VAR estimate, $p_{1}$ and $p_{2}$ are the number of lags used in the estimation of the two VARs. The null hypothesis under investigation here is that there is no structural change due to the adoption of inflation targeting in the economy of country $j$, where $j=$ South Africa, Brazil and Chile).

Hence, after this illustration of the theoretical framework of the approaches used in the empirical part of this paper it is now appropriate to discuss the steps of the estimation procedure 
and the results. I start with discussing the SVARs and estimation results obtained for the three countries and then I end up with the results of the Likelihood Ratio (LR) statistic estimation.

\subsection{Estimation and Results:-}

\subsubsection{VAR and SVARs Estimates:}

The benchmark specification of the unrestricted VARs and Structural VARs consists of four variables: inflation rate, output gap, the policy variables that are specified by the policymaker of the monetary policies in those countries during the pre-inflation targeting as well as the adoption periods of this regime (e.g. I have used the rate of change in the logarithmic transformation of monetary aggregates to indicate the policy variable during the pre-adoption period, whereas, I have utilized the money market rate during the adoption periods in the VARS and SVAR estimates of the two periods of interest). The fourth variable is the rate of change in the logarithmic transformation of the nominal exchange rate. Those series have been assembled on quarterly basis for Brazil, Chile, and South Africa.

The key constraint that I have faced in estimating monetary policy VARs and SVARs in those three emerging market economies was the existence of non-interpolated quarterly data on some variables spanning for long enough periods. I have assembled the relevant data for the three countries over the period (1970:Q1 - 2007:Q4) from different data sources. $\stackrel{42}{ }$

Variables are expressed in logarithmic transformed terms, except the money market rate and inflation rate. Furthermore, unit root tests have been performed on these time series to determine whether they have a unit root or not. Table: (A-1) in the appendix shows the order of integration of the time series used for the three courtiers of interest. The VAR uses a stationary

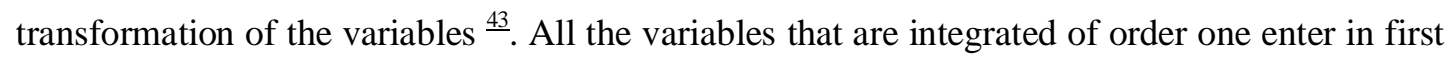
differences, while the series that are integrated of order two enters in second difference. On the other hand, stationary series (which are integrated of order zero) enter in levels. Then, I have tested whether the chosen VAR has satisfactory properties..$^{44}$

\footnotetext{
$\underline{42}$ I have had to convert the frequency of some annual and monthly data series into quarterly data. (For more details about the variables used and the data sources, refer to appendix).

$\underline{43}$ There is a large debate on whether to include stationary or non-stationary variables in VAR estimation .However, it is essential for the stationarity of the VAR to perform unit root tests in the time series used in it. Therefore, the Augmented Dickey Fuller test has been performed and the included series were determined depending on the result of this test. See, table: (A-1) in the appendix.

44 Therefore, I have checked if the residuals are stationary, normal and not auto-correlated. A visual inspection of the residuals revealed that there were no major outliers. Multivariate serial correlation of the residuals has been tested to determine if the residuals were stationary. In this regard, a residual serial correlation Lagrange Multiplier (LM) test has been used to test the null hypothesis of no serial correlation for the residuals of the estimated VARs.
} 


\section{The main Steps of the estimations are summarized as follows:}

- For South Africa, I have estimated a VAR spans from 1970:Q1 to 1999:Q4 indicating the pre-inflation targeting period. The variables in this VAR are the first difference of inflation rate $d($ infl_sa), output gap (outputgap_sa), the rate of change in the logarithmic transformation of monetary aggregates ( $\left.m_{3 \_} s a \_r a t e\right)$, and the rate of change in the logarithmic transformation of the nominal exchange rate (nom_er_sa_rate). I have used $\left(\mathrm{M}_{3}\right)$ instead of any other definition of monetary aggregates in this VAR estimate due to the fact that the South African Reserve Bank adopted the monetary targeting regime which depended mainly on $\mathrm{M}_{3}$ as a way to perform its monetary policy before the announcement of the adoption of inflation targeting regime. ${ }^{45}$

- Standard lag length selection criteria are usually used to select the number of lags of the VAR. I have used Schwarz Information Criterion (SC) to coincide between the need for providing a good specification and the possibility of loosing observations. The usage of (SC) has showed that the best lag length of the VAR was three lags, which helped to obtain a stable VAR.

- The impulse response functions have been obtained from the VAR that covers the preinflation targeting period. (See, Figure B-B1 in the appendix).

- Then, another VAR estimated for the period of inflation targeting adoption which spans from 2000:Q1 to 2007:Q4. Using the variables d(infl_sa), (outputgap_sa), (nom_er_sa_rate). But, this time instead of monetary aggregate series, I have used the first difference of the money market rate $d\left(m m r_{-} s a\right)$. This indicates that -under inflation targeting- there is no role for monetary aggregates. Depending on Schwartz information (SC) criterion, I have utilized lag of three quarters.

- The impulse response functions have been obtained from the VAR that covers the inflation targeting period. (See, Figures B-B2)

- The above-unrestricted VAR models that cover the pre-inflation targeting period and the adoption period have represented the essential basis towards obtaining two SVARs to see differences in the responses to structural shocks because of the inflation targeting regime.

$\underline{45}$ This has been indicated in sub-section 4.3 of this paper that has discussed the monetary policy performance in South Africa and in table (2). 
- In order to estimate the SVAR models, I have to impose some restrictions in terms of the residuals from the VAR estimates and the stochastic errors (or innovations) in the structural system.

- The first SVAR for South Africa covers the period from 1970:Q1 to 1999:Q4 (i.e. it covers the pre-inflation targeting period). These restrictions are short-term; I have tried to choose them depending on the theory and the features of the periods under investigation. Those identification restrictions indicate the following:

(i) Inflation rate responds to its innovation, to changes in monetary aggregates and to changes in nominal exchange rate. The main aim of this restriction is to capture the fact that monetary aggregates represented the focus of monetary targeting regime adopted in this period to maintain lower rates of inflation. Furthermore, this restriction indicates that there is contemporaneous pass-through and shows that exchange rate played the role of a nominal anchor that characterized the period under investigation. Hence, this restriction has its counterpart support in the widespread literature that investigated the relation between inflation, monetary aggregates and exchange rates.

(ii) Output gap is affected by its own innovation and shocks to inflation rates. This restriction is imposed to show that there is no role played by monetary policy in affecting output. The main goal of monetary policy is to maintain lower inflation rates with no objective to achieve any output target. In addition, this restriction indicates that high inflation also leads to variability in inflation that can be costly for the economy. This also coincides with the theory that focuses on the relation between inflation and economic performance, especially, in the short-run.

(iii) Whereas, monetary aggregates respond to its own innovation, the shocks to inflation rate and to innovation in output gap. This restriction shows that the pre-inflation targeting period were concentrating on the path of monetary aggregate and it takes into account the innovation in inflation and technological improvements. Which implies that the policymaker when he sets the policy variable takes into consideration the behaviour of other important macroeconomic variables.

(iv) Finally, exchange rate responds to its innovation and to shocks in inflation rate. This restriction captures the direct relation between inflationary pressures and the behaviour of 
exchange rate that represents the main interest of the literature in the context of emerging market economies. $\underline{46}$

This means that the direct link that goes from exchange rate to inflation is captured by the restriction (i), whereas, the relation that goes to the reverse direction is captured by restriction (iv).

- The estimated Structural VAR has been just identified after only one iteration; indicating a valid restriction scheme. Another identification schemes have been tried but they have not been satisfied by the data. Figure (B-B3) shows the generated impulse response functions. The accumulated response to structural one standard deviation innovations obtained from the SVAR estimates for the pre-inflation targeting period is illustrated in table (A-3).

- The Second SVAR spans from 2000:Q1 to 2007:Q4 (i.e. it covers the inflation targeting period). I have used the same identification as the pre-inflation targeting. However, the only difference is that instead of using monetary aggregates as the policy variable; I have used the first difference of money market rate to show the lack of the importance of monetary aggregates in this period and the emphasis of monetary authority on short-term interest rates as the instrument of its monetary policy.

- The estimated Structural VAR has been just identified indicating a valid identification that suits the data. Another identification schemes have been tried but they have not been satisfied by the data. Table (A-4) shows the generated cumulative impulse response functions.

- For Brazil, I have done the same analysis. The first estimated VAR covers the preinflation targeting period from 1970:Q1 to 1999:Q2. The variables used in this VAR were inflation rate (infl_br), output gap (outputgap_br), the rate of change in the logarithmic transformation of monetary aggregates $\mathrm{M}_{1}\left(m_{1 \_} b r \_r a t e\right)$, and the rate of change in the logarithmic transformation of the nominal exchange rate (nom_er_br_rate). The lag length due to (SC) criterion has been four lags. Also, this VAR is stable. The impulse response function from this VAR is illustrated in (Figure: B-B5 in the appendix).

- Another VAR is estimated for the period of inflation targeting adoption which spans from 1999:Q3 to 2007:Q4. Using the variables (infl_br), (outputgap_br) and (nom_er_br_rate). However, this time instead of monetary aggregate series, I have

\footnotetext{
${ }^{46}$ For instance: Ho and McCauley (2003), and Agénor (2000). However, the main focus of those authors was the relation between exchange rate and inflation in the context of inflation targeting regime.
} 
used the money market rate $\left(m m r_{-} b r\right)$ to indicate the importance of short-term interest rate in the context of inflation targeting framework.

- The next step was to estimate the Structural VARs. I used the previous mentioned two VARs (i.e. the one for the pre-inflation targeting and the one for the adoption period) with the same restrictions imposed in the South African case. The estimated SVARs have been just identified after one iteration. Also, I have obtained the accumulated impulse responses of the SVARs estimates for the two periods.

- For Chile, I have done the same steps. I have estimated a VAR spans from 1970:Q1 to 1990:Q3 for the pre-inflation targeting period. The variables used in this VAR were the first difference of inflation rate $d($ infl_ch), Output gap (outputgap_ch), the rate of change in the logarithmic transformation of monetary aggregates $\mathbf{M}_{1}\left(m_{1} \_c h \_r a t e\right)$, and the rate of change in the logarithmic transformation of the nominal exchange rate (nom_er_ch_rate). The lag specification was twelve due to (SC) criterion.

- Another VAR estimated for the period of inflation targeting adoption that goes from 1990:Q4 to 2007:Q4. Using, the variables d(infl_ch), (outputgap_ch). However, this time instead of monetary aggregate series I used the average interest rate because of the non-availability of money market rate or any proxy for short-term interest rates for the period of study and this variable entered in its $2^{\text {nd }}$ difference to guarantee the stability of the estimated VAR (i.e.d(interst_Chile,2)). In addition, I have used (nom_er_ch_rate). The lag length was four according to (SC) criterion.

- The further step was to estimate the Structural VARs through imposing the same scheme considered in the previous cases of South Africa and Brazil. The estimated Structural VARs were also just identified, indicating a valid identification. In addition, tables (A-7 and A-8) show the generated accumulated responses obtained from the two estimated SVARs.

\section{The most remarkable results obtained from the above analysis:}

For South Africa, comparing the responses to Cholesky identification obtained from the estimated VARs for the pre-inflation targeting and the adoption periods shows that an exogenous increase in the monetary policy variable used during the pre-inflation targeting period leads to an increase in inflation rate but this response of inflation dies out after the $10^{\text {th }}$ quarter. Overall, this impact is stronger at this period compared to the response of the inflation rate to the policy variable during the inflation targeting period (i.e. money market rate) which appears until the $3^{\text {rd }}$ quarter. Afterwards, there is almost no impact on inflation rates. 
There is a considerable response of output gap to shocks in the monetary policy variable- as indicted by the responses to Cholesky identification obtained from the estimated VARs for the pre-inflation targeting period- but after 12 quarters, the output gap returns to its initial level, showing that monetary policy does not affect output in the long-run. However, under inflation targeting period, the response of output gap to monetary policy variable was zero on average.

On the other hand, the inflation rates responds to shocks in nominal exchange rate but this response was very sluggish, indicating a very slow pass-through of exchange rates in the preinflation targeting period. However, under inflation targeting, the response of inflation to shocks in nominal exchange rate is more considerable in the first 5 quarters compared to that of the monetary policy instrument, indicating that there is a pass-through effect. This is surprising me, because under inflation targeting the more effective tool to achieve the target is the monetary policy instrument that should have the considerable impact on inflation rates, but what I have found here, is a considerable impact of nominal exchange rates on inflation rates. This shows the need for imposing restrictions and using the SVAR estimation.

Hence, after imposing restrictions and obtaining SVARs, the comparison of the accumulated responses to structural one standard deviation innovations obtained from the estimates for the pre-inflation targeting and the adoption periods shows that; up to the $12^{\text {th }}$ quarters the innovation of a one percentage point in the monetary policy variable induces a total accumulated change on inflation rate of 1.36 percentage point ( before the adoption of inflation targeting regime) compared with a negative impact of 0.45 percentage point (after the announcement of inflation targeting). This indicates that monetary targeting was not effective under the pre-inflation targeting period. Also, it shows that the move to inflation targeting regime helped to achieve its price stability objective by adjusting short-term interest rate.

In addition, the innovation of one percentage point in the nominal exchange rate variable induces a total accumulated change on inflation rate of negative 0.13 percentage point before the adoption of inflation targeting and it induced a positive impact of 0.04 percentage point after inflation targeting. This implies that; after the adoption of inflation targeting the pass through effect is still appearing which coincide with the outcome of graphical inspection of the responses to Cholesky identification obtained from the estimated VARs. Interestingly, this is a feature that is common in emerging market economies where in practice still exchange rate plays a direct impact on inflation rates and it is impossible in inflation targeting framework for the central bank in those countries to commit itself to only one nominal anchor.

Furthermore, after three years, the one time innovation of one percentage point in the monetary policy variable (whether monetary aggregates or the money market rate) induces 
approximately no impact on output gap in both periods, showing that monetary policy does not have a considerable affect on output in the long-runs under the two periods.

For Brazil, the responses to Cholesky identification obtained from the estimated VAR for the pre-inflation targeting period shows that an increase in the monetary policy variable (i.e. monetary aggregate series) leads to no significant impact -on average- on inflation rate which indicates that the response of inflation rate to monetary policy shock was not strong in the preinflation targeting period. However, for the inflation targeting period, there is a significant response of the inflation rate to money market rate- especially in the short to medium termscompared to the pre-inflation targeting period.

In addition, there is almost no response of output gap to shocks in monetary policy variable in the pre-inflation targeting period. However, there is a considerable negative impact after the adoption of this regime. Furthermore, the inflation rates responds more strongly to shocks in nominal exchange rate after the change in regime. Under inflation targeting, the response of inflation rates to shocks in nominal exchange rate has a pattern that is quite similar to that of the monetary policy instrument, indicating that there is a pass through effect. However, during inflation targeting, the response of inflation rate to nominal exchange rate is more significant in the short term compared to the response of inflation rate to money market rates. This leads to the same surprise that I found in the South African case, (i.e. I have found nominal exchange rates playing a key role in affecting inflation rates). While, according to theoretical aspects of inflation targeting regime it should be the case that the monetary instrument, only, has the considerable impact on inflation rates. This also shows the need for imposing short-term restrictions using Structural VAR approach.

Hence, after imposing restrictions and obtaining SVARs, the comparison of the accumulated responses to structural one standard deviation innovations obtained from the estimates for the pre-inflation targeting and the adoption periods shows that up to the $12^{\text {th }}$ quarters, the innovation of a one percentage point in the monetary policy variable induces a total accumulated change on inflation rate of 34.64 percentage point (before the adoption of inflation targeting regime) compared with a 0.09 percentage point (after the announcement of inflation targeting).

Moreover, the innovation of one percentage point in the nominal exchange rate variable induces a total accumulated change on inflation rate of 5.73 percentage points before the adoption of inflation targeting and it induced a positive impact of 0.61 percentage point after inflation targeting. This implies that after the adoption of inflation targeting the pass through effect is still appearing but it has been mitigated by the adoption of inflation targeting regime. 
This also copes with the outcome of graphical inspection of the responses to Cholesky identification obtained from the estimated VARs and indicates that exchange rates plays a role under inflation targeting regime. Also, up to the $12^{\text {th }}$ quarter, the one time innovation of one percentage point in the monetary policy variable (whether monetary aggregates or the money market rate) induces approximately no impact on output gap in both periods, showing that monetary policy does not have a considerable affect on output in the long-runs under the two periods.

For Chile, the responses to Cholesky identification obtained from the estimated VARs for the pre-inflation targeting period and the adoption periods shows that the response of inflation rate to monetary policy shock was stronger in the pre-inflation targeting period compared to, almost, no impact in the adoption period. Also, there is a response of output gap to shocks in monetary policy variable before the implementation of inflation targeting. However, this response dies out in the long-run, specifically after the $10^{\text {th }}$ quarter, showing that monetary policy does not affect output in the long-run. In addition, there is no strong response of output gap to monetary policy shocks under inflation targeting.

On the other hand, the inflation rates do respond to shocks in nominal exchange rate, indicating a pass-through effect of exchange rate before the change in the regime. Nevertheless, the response of inflation rate to shocks in nominal exchange is almost zero under inflation targeting, indicating a pattern that differs from South Africa and Brazil where the pass-through effect played a key role during the inflation targeting period. This in turn shows the need to impose some restrictions in order to show whether it is possible to have exchange rate playing a role as well as the monetary instrument in affecting inflation or not.

Therefore, comparing the accumulated responses to structural one standard deviation innovations obtained from the SVARs estimated for the pre-inflation targeting and the adoption periods shows that, after three years, the innovation of a one percentage point in the monetary policy variable induces a total accumulated change on inflation rate of negative 3.79 percentage point (before the adoption of inflation targeting regime) compared with a 0.99 percentage point (after the announcement of inflation targeting). In addition, the innovation of one percentage point in the nominal exchange rate variable induces a total accumulated change on inflation rate of 9.79 percentage points before the adoption of inflation targeting and it induced a negative impact of 0.99 percentage point after inflation targeting. This implies a different outcome compared to the South African and Brazilian cases where, the Chilean case shows the absence of the role of exchange rates in inflationary pressures under the adoption of inflation targeting regime. This also copes with the outcome of graphical inspection of the 
responses to Cholesky identification obtained from the estimated VARs. Also, up to the $12^{\text {th }}$ quarter, the one time innovation of one percentage point in the monetary policy variable (whether monetary aggregates or the money market rate) induces approximately no impact on output gap in both periods, showing that monetary policy does not have a considerable affect on output in the long-runs under the two periods.

To sum up, the above analysis shows that, in the three countries of interest, pre- inflation targeting period shows the unsatisfactory results of monetary targeting and pegged exchange rates as nominal anchors and the importance to move towards the inflation targeting regime. Up to 12 quarters the cumulative impact of monetary policy shocks on output gap is almost zero, indicating that inflation targeting did not lead to macroeconomic effect in these countries. However, the impact of monetary policy shocks on inflation rates is mixed -under inflation targeting- between a negative impact in South Africa and a no considerable one in the cases of Brazil and Chile.

On the other hand, using the results obtained from Structural VAR estimation, I have found a common characteristic under inflation targeting regime - in the South Africa and Brazil (but I have not found it in Chile) - that is the exchange rate plays a direct impact on inflation rates and it is impossible for the central bank in those countries to commit itself to only inflation targets as nominal anchors. This implies the need for further improvements in the exchange markets of those two countries because those countries- as the case in most of the emerging market economies- are more vulnerable to external shocks and to exchange rate fluctuations. Interestingly, the empirical finding in this paper coincides with the general remarks about emerging market economies which has been mentioned by Ho and McCauley (2003, pp. 2-3) $\frac{47}{4}$ who have showed that, emerging market economies tend to be relatively more vulnerable to the various consequences of exchange rate fluctuations than are industrial economies. The greater vulnerability arises from, among other possible factors, patterns of consumption associated with relatively low incomes and histories of higher inflation. Thus, exchange rate considerations figure more prominently in policymaking in emerging market economies than in their industrial economy counterparts, regardless of the specific policy regime. Furthermore, even under a strict construction of inflation targeting, exchange rate considerations can be expected to play a more prominent role in emerging market economies, given the greater sensitivity of their domestic

$\underline{47}$ The main motive of their paper was examining two main issues. The first was why the exchange rate matters, especially for emerging market economies. The second was under what circumstances and how countries had dealt with the challenges posed by the exchange rate in the context of inflation targeting. (For more details, refer to Ho and McCauley (2003)). 
prices to the exchange rate. Hence, exchange rate movements appear to have posed significant challenges to emerging market inflation targeters.

Therefore, using VARs and SVARs estimates has provided a picture of the response of nonpolicy variables to monetary policy shocks. However, I have obtained mixed results which cannot provide an answer to the following question: "Did the adoption of inflation targeting regime lead to structural changes in the economies of South Africa, Brazil and Chile?".

Therefore, as a further step, I use the simple Likelihood Ratio (LR) statistic test to provide an answer to this important question.

\subsubsection{The Log Likelihood Ratio (LR) Statistic:}

In order to identify the possible effects of inflation targeting on macroeconomic variables, I have estimated the (LR) Statistic to test for structural changes due to the adoption of inflation targeting in those countries. I have used five variables unrestricted VAR. Those variables were inflation rate (infl), output gap (outputgap), monetary aggregate. Concerning the third variable, it is known that there are many definitions of monetary aggregates but, I have utilized $\mathrm{M}_{3}$ (i.e. $\left.l m_{3}\right)$ in the VAR estimate for South Africa and $\mathrm{M}_{1}$ (i.e. $\left.l m_{1}\right)$ in the VAR estimates for Brazil and Chile. The fourth variable is the money market rate (in the case of South Africa and Brazil) and

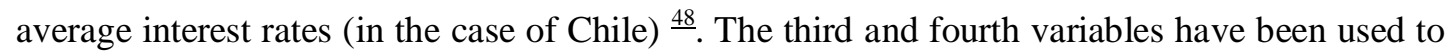
consider the policy variables specified by the monetary authority.

The fifth variable is the (nominal exchange rate, log) (Inom_er). Those five variables were used in the estimation of the pre-inflation targeting and the adoption periods of this regime as well as for the whole sample estimation. I have followed three steps to end up with a (LR) Statistic:

(i) I have estimated VARs, using the above-mentioned five variables and depending mainly on the data that covers the pre-inflation targeting period (from 1970:Q1 to 1999:Q4 for South Africa, from 1970:Q1 to 1999:Q2 for Brazil, and from 1970:Q1 to 1990:Q3 for Chile). Then, I have determined the appropriate lag length of the estimated VARs using the Schwarz Criterion (SC) and I have followed the same procedure of analysis -mentioned before- in order to check for the properties of the estimated VARs and the residuals. The appropriate lag length is 3 lags for both South Africa and Brazil VAR estimates for this period. Whereas, it is 12 lags for Chile

\footnotetext{
${ }^{48}$ Due to the non-availability of money market rate for Chile that spans along the period of interest from 1970:Q1 to
} 2007:Q4. 
estimates and the estimated VARs were stable ${ }^{49}$. Then; I have obtained the log likelihood for the pre-inflation targeting period.

(ii) I have estimated VARs with the same mentioned variables but the data cover the adoption period of inflation targeting (from 2000:Q1 to 2007:Q4 for South Africa, from 1999:Q3 to 2007:Q4 for Brazil, and from 1990:Q4 to 2007Q4 for Chile). The appropriate lag length -using the Schwarz Information criterion - is 3 lags for South Africa and 4 lags for Brazil VAR estimates and Chile. Then; I have obtained the log likelihood for the inflation targeting adoption period.

(iii) The log likelihood of the unrestricted model obtained by summing up log likelihood obtained form steps (i) and (ii), I have called it (likelihood_ur).

(iv) I estimated VARs with the same mentioned variables but the currently used data covers the whole period of this study (i.e. from 1970:Q1 to 2007:Q4) for the three countries. The lag length for the estimated VAR for South Africa and Brazil is 3 lags, whereas, the lag length for the equivalent VAR for Chile is 5 lags.

Then, I have obtained the log likelihood for the whole period, this represents the log likelihood of the restricted model, I called it (likelihood_r).

(v) Now, it is the step to compute the log likelihood ratio statistic, which takes in our analysis the following form:

(LR) Statistic $=2($ likelihood_ur - likelihood_r $) \sim X^{2}\left(n^{2}\left(p_{u r}-p_{r}\right)\right)$

Where, (likelihood_ur) and (likelihood_r) are the maximized values of the unrestricted and restricted models, respectively. The (LR) test statistic has an asymptotic $X^{2}$ distribution with degrees of freedom equal to $\left(n^{2}\left(p_{u r}-p_{r}\right)\right)$ under the null hypothesis of no structural change, where $\mathrm{n}$ is the number of varibles (i.e 5 variables). $\mathrm{p}_{u r}$ and $\mathrm{p}_{\mathrm{r}}$ are the number of lags used in the estimation of the unrestricted and restricted models, respectively. The following table summarizes the obtained results and the steps followed to obtain the Likelihood Ratio ((LR)) statistic and the tabulated values that should be compared with the computed one to see whether the null is rejected or not in the three countries.

${ }^{49}$ I have already discussed the steps of the analysis that I follow in estimating unrestricted VARs at the beginning of sub-section 5.2 of this paper. The only difference is that, here, I use 5 variables VAR estimate. While, at the commencement of the said sub-section I was using 4 variables VAR estimate. 
Table(4): The Computation of the Likelihood Ratio (LR) Statistic Through Using 5 Variables VAR Estimates

\begin{tabular}{|l|c|c|c|}
\hline & $\underline{\text { South Africa }}$ & $\underline{\text { Brazil }}$ & $\underline{\text { Chile }}$ \\
\hline (1)Log likelihood for the pre-inflation targeting period & 773.0704 & -612.2310 & 867.6685 \\
\hline (2) Log likelihood for the inflation targeting period & 364.5939 & 361.6919 & 554.2611 \\
\hline (3) Log likelihood for the whole period (likelihood_r) & 984.3229 & -769.5190 & 416.3217 \\
\hline $\begin{array}{l}\text { (4)Log likelihood of the unrestricted model obtained by } \\
\text { summing up rows (1) and (2) (likelihood_ur) }\end{array}$ & 1137.6643 & -250.5391 & 1421.9296 \\
\hline $\begin{array}{l}\text { (5)(LR) Statistic= 2(likelihood_ur-likelihood_r) } \\
\left.\text { (6) Degrees of freedom ( }{ }^{2}\left(p_{u r}-p_{r}\right)\right)\end{array}$ & 306.6828 & 1037.9598 & 2011.2158 \\
\hline $\begin{array}{l}\text { (7)Tabulated values from statistical tables at 5 percent } \\
\text { significance level } *\end{array}$ & 79.08 & 79.08 & 146.57 \\
\hline
\end{tabular}

Note: $(*)$ The tabulated values are obtained from (Pindyck and Rubinfeld ,1998, p. 604).

The above table clearly shows that the (LR) Statistic is greater than the tabulated value. So, the null hypothesis of no structural changes due to the adoption of inflation targeting is rejected. This, in turn, indicates that there is a structural change in those countries. This provides empirical evidence (through using simple statistic) that the adoption of inflation targeting has an impact on macroeconomic variables in the three countries of interest.

\section{Conclusion and Policy Implication:-}

This paper investigates the monetary policy performance in Brazil, Chile and South Africa under inflation targeting framework. It provides an empirical assessment through using the unrestricted Vector Auto-regression (VAR) and Structural Vector Auto-regression (SVAR) approaches depending on data spans from the first quarter of 1970 to the fourth quarter of 2007. Furthermore, it uses a simple Likelihood Ratio (LR) Statistic to test for structural changes due to the adoption of inflation targeting regime in those countries.

The main results are as follows. In first place, the analysis shows that inflation targeting does make a difference in the performance of monetary policy in those countries. It indicates an improvement in main macroeconomic indicators after the adoption of inflation targeting compared to the pre-adoption period. Secondly, the estimation of the Likelihood Ratio (LR) statistic shows structural changes in the three economies of interest due to the adoption of inflation targeting regime. This implies that the implementation of inflation targeting regime is an appropriate step towards achieving economic stabilization and strengthening the ability of 
those economies to overcome external shocks. However, those countries are still affected by exchange rate fluctuations that are partially mitigated by inflation targeting regime. Therefore, further steps have to be achieved to protect those economies through developing the foreign exchange markets and building up their international reserves.

Thirdly, the experience of Brazil, Chile and South Africa provide lessons that can lead to the enthusiasm of other emerging market economies to adopt such a framework. Those lessons are:

(1) It is not necessarily the fulfillment of the all perquisites for the adoption of inflation targeting regime.

(2) It is possible for any emerging market economy that is suffering from high rates of inflation to imitate the South African experience. This can be through practicing a transition period from informal to formal inflation targeting. Such a transition period improves the credibility of the country's monetary policy and enhances its confidence to announce the adoption of full-fledged inflation targeting regime as a further step.

(3) The three experiences illustrate the importance of financial developments in order to guarantee the instrument independence of the central bank in the context of inflation targeting. This will help in avoiding the inflationary financing of the government deficit.

(4) Exchange rates still play a key role in the context of inflation targeting regime. So, it is possible for any emerging market economy that is looking for the adoption of inflation targeting to mitigate the vulnerability of its economy to exchange rate fluctuations through the adoption of this regime. However, during the first years of the adoption the announced inflation targets may not be fulfilled because of these fluctuations. Nevertheless, after enhancing monetary policy credibility under inflation targeting regime and reforming the exchange rate markets, marvelous outcomes can be achieved through capturing the pass-through effect of exchange rate on inflation rates as the empirical results for South Africa and Brazil indicates.

(5) Coordination between monetary and fiscal authorities is important- under inflation targeting- as it indicates the responsibility of both authorities in providing the suitable economic environment to achieve the target. This is clear through the open letter that has to be sent by the governor of the Brazilian Central Bank to the minister of finance if the target has been breached and it is obvious in the case of South Africa where the minister of finance does the announcement of the inflation target. 


\section{References:-}

1. Agénor, Pierre-Richard (2000), "Monetary Policy under Flexible Exchange Rates: An Introduction to Inflation Targeting", World Bank Policy Research, Working Paper No. 2511, the World Bank.

2. Amato, Jeffery D. and Gerlach, Stefan (2002), "Inflation Targeting In Emerging Market and Transition Economies: Lessons After a Decade", European Economic Review, Volume 46, pp.781 - 790, May.

3. Angeriz, Alvaro and Arestis, Philip (2008), “Assessing Inflation Targeting Through Intervention Analysis", Oxford Economic Papers, Oxford University Press, Volume 60, Number 2, pp. 293-317.

4. Bagliano, F. C. and Favero, C.A. . (1998), "Measuring Monetary Policy with VAR Models: An Evaluation”', European Economic Review, Volume 42, Number 6, pp. 1069-1112.

5. Ball, Lawrence, and Sheridan Niamh, (2005), "Does Inflation Targeting Matter?" In "the Inflation-Targeting Debate" edited by: Bernanke, Ben S., and Woodford, Michael, University of Chicago Press.

6. Bernanke, Ben S., Laubach, Thomas, Mishkin, Frederic S., and Posen, Adam S. (1999), "Inflation Targeting: Lessons from the International Experience", Princeton University Press.

7. Bernanke, Ben S. and Mishkin, Frederic S. (1997), "Inflation Targeting: A New Framework for Monetary Policy?", The Journal of Economic Perspectives, Volume 11, Issue 2(spring), pp. 97-116.

8. Betancour, Cristina, De Gregorio, José and Medina, Juan, Pablo, (2008), "The great moderation and the monetary transmission mechanism in Chile", Bank for International Settlements (BIS) Papers chapters, in: Bank for International Settlements (ed.), Transmission mechanisms for monetary policy in emerging market economies, volume 35, pages 159-178.

9. Bofinger, Peter (2001), "Monetary Policy: Goals, Institutions, Strategies, and Instruments", Oxford University Press, the United Kingdom.

10. Bogdanski, Joel, Tombini, Alexandre, Antonio and Werlang, Sérgio Ribeiro C. (2000), "Implementing Inflation Targeting in Brazil", the Brazilian Central Bank, Working Paper Series, No. 1, July.

11. Boivin, Jean and Giannoni, Marc (2002), "Assessing Changes in the Monetary Transmission Mechanism: A VAR Approach", Federal Reserve Bank of New York, Economic Policy Review. Available at: http://www.newyorkfed.org/research/epr/02v08n1/0205boiv.pdf

12. Brazilian Central Bank (2003),"Open Letter sent by Brazilian Central Bank's Governor, Henrique de Campos Meirelles, to the Minister of Finance, Antonio Palocci Filho", January. Available at: http://www.bcb.gov.br/ingles/relinf/OpenLetter2003.pdf

13. Brazilian Central Bank (1999), "Monetary Policy Operating Procedures in Brazil" paper in "Monetary Policy Operating Procedures in Emerging Market Economies", Bank of International Settlements (BIS), Policy Papers No.5, March.

14. Buckle, Robert A., Kim, Kunhong, Kirkham, Heather, McLellan, Nathan and Sharma, Jared (2002), "A structural VAR model of the New Zealand business cycle", New Zealand Treasury, Working Paper No. 02/26, December.

15. Calvo, Guillermo A. and Reinhart Carmen M. (2000), "Fear of Floating", NBER Working Paper, No. 7993, November.

16. Carare, Alina and Stone, Mark R. (2006), "Inflation Targeting Regimes", European Economic Review, Volume 50, Issue 5, pp. 1297-1315, July. 
17. Casteleijn, Anton (2001), "South Africa's monetary policy framework". South African Reserve Bank. Available at: http://www.reservebank.co.za/internet/Publication.nsf/LADV/A4A0DAB6223DB26E42257051 004105AE/\$File/SouthAfrica.pdf

18. Céspedes, Luis, F. and Soto, Claudio (2006), "Credibility And Inflation Targeting In Chile", Central Bank of Chile, Working Paper No. 408, December.

19. Christ, Carl F. (1994), "The Cowles Commission's Contributions to Econometrics at Chicago, 1939-1955", Journal of Economic Literature, Volume 32, No. 1, March, pp. 30-59.

20. Dixit, Avinash, and Lambertini, Luisa (2003), "Interactions of Commitment and Discretion in Monetary and Fiscal Policies, the American Economic Review, Volume 93, pp. 1522-1542.

21. Elbourne, Adam and de Haan, Jakob (2005), "Modeling Monetary Policy Transmission in Accession Countries: VAR vs SVAR". Available at: http://www.eco.rug.nl/medewerk/elbourne/transmodel.pdf

22. Faust, Jon, Swanson, Eric T. and Wright, Jonathan H. (2004), "Identifying VARs based on high frequency futures data", Journal of Monetary Economics, 51, pp. 1107-1131

23. Gonçalves, Carlos, Eduardo S. and Salles, João M. (2008), "Inflation Targeting in Emerging Economies: What Do the Data Say?, Journal of Development Economics, Volume No.85, pp. 312-318.

24. Hamilton, D., James (1994), “Time Series Analysis", Princeton University Pres, New Jersey.

25. Harjes, Thomas and Ricci, Luca, Antonio (2008), "A Bayesian-Estimated Model of Inflation Targeting in South Africa", International Monetary Fund, Working Paper No. 48, February.

26. Ho, Corrinne and McCauley N. Robert (2003), "Living with flexible exchange rates: issues and recent experience in inflation targeting emerging market economies", the Bank for International Settlement (BIS), Working Papers No 130.

27. Honda, Yuzo (2000), "Some Tests On the Effects of Inflation Targeting In New Zealand, Canada, and the UK", Economics Letters, Volume 66, Issue 1, pp. 1-6, January.

28. Johnson, David R. (2002), "The Effect of Inflation Targeting on the Behavior of Expected Inflation: Evidence from an 11 Country Panel", Journal of Monetary Economics, Volume 49, 2002, pp.1521-1538.

29. Kim, Soyoung and Roubini, Nouriel (2000), "Exchange Rate Anomalies in the Industrial Countries: A solution with a structural VAR Approach", Journal of Monetary Economics, Volume 45, Issue 3, pp. 561-586.

30. Kim, Soyoung (1999), "Do Monetary Policy Shocks Matter In The G-7 Countries? Using Common Identifying Assumptions about Monetary Policy across Countries", Journal of International Economics, Volume 48, pp. 387 -412.

31. Landerretche, Oscar, Morandé, Felipe, and Schmidt-Hebbel, Klaus, (1999), "Inflation Targets and Stabilization in Chile", Central Bank of Chile, Working Papers, No.55, December.

32. Levin, Andrew T., Natalucci, Fabio M., and Piger Jeremy M.(2004), "The Macroeconomic Effects of Inflation Targeting", Federal Reserve Bank of St. Louis Review, Volume 86, No. 4, pp. 51-80, July/August.

33. Leeper, E.M., C.A. Sims and T. Zha (1996), "What Does Monetary Policy Do?", Brookings Paper on Economic Activity, Volume 1996, No. 2, pp. 1-63.

34. Lütkepohl Helmut (2006), "New Introduction to Multiple Time Series Analysis", Springer-Verlag Berlin and Heidelberg GmbH \& Co. KG. 
35. Masson, Paul R., Savastano, Miguel A. and Sharma, Sunil (1997), "The Scope for Inflation Targeting in Developing Countries," International Monetary Fund, Working Paper No.130, October.

36. Meyer, Laurence H. (2002), "Inflation Targets and Inflation Targeting", North American Journal of Economics and Finance, Volume 13, pp. 147-162.

37. Minella, Andre', de Freitas, Paulo, Springer, Goldfajn, Ilan, and Muinhos, Marcelo, Kfoury (2003), "Inflation targeting in Brazil: Constructing Credibility under exchange rate volatility", Journal of International Money and Finance, Volume 22 , Issue 7, pp. 1015-1040, December.

38. Mishkin, Frederic S. (2007), "Monetary Policy Strategy", Published by MIT Press.

39. Mishkin, Frederic S. (2004), "Can Inflation Targeting Work In Emerging Market Countries?", NBER Working Paper Series, No. 10646, July.

40. Mishkin, Frederic S. and Savastano, Miguel A. (2001), "Monetary policy strategies for Latin America", Journal of Development Economics, Volume. 66, Issue 2, pp. 415444, December.

41. Mishkin, Frederic S.(2000), "Inflation Targeting in Emerging-Market Countries", The American Economic Review, Volume 90, No. 2, Papers and Proceedings of the One Hundred Twelfth Annual Meeting of the American Economic Association, pp. 105 109, May.

42. Mishkin, Frederic, S. and Adam Posen. S.(1997), "Inflation Targeting: Lessons from Four Countries", Economic Policy Review, Federal Reserve Bank of New York, Volume 3, Number 4, pp 9-110, December,

43. Mitchell-Innes, H.A., Aziakpono M. J. and Faure, A.P.(2007), "Inflation Targeting and the Fisher Effect in South Africa: An Empirical Investigation", South African Journal of Economics, Volume No. 75, Issue 4, pp. 693-707, December.

44. Pindyck, Robert S., and Rubinfeld Daniel L.(1998), “ Econometric Models and Economic Forecasts", McGraw-Hill international edition, fourth edition.

45. Roger, Scott and Stone, Mark (2005), "On Target?, The International Experience with Achieving Inflation Targets", International Monetary Fund, Working Paper No. 136, August.

46. Rogoff, K. (1985), "The Optimal Degree of Commitment to an Intermediate Monetary Target", Quarterly Journal of Economics, Volume 100, No. 4, pp. 1169-1189.

47. Schmidt-Hebbel, Klaus and Tapia, Mat'1as (2002), "Inflation targeting in Chile", North American Journal of Economics and Finance, Volume 13, pp.125-146.

48. Schmidt-Hebbel, Klaus, and Werner, Alejandro (2002), "Inflation Targeting in Brazil, Chile, and Mexico: Performance, Credibility, and the Exchange Rate", Economia, spring, pp 31-88.

49. Sims, C.A., Zha, T.( 1998), "Does monetary policy generate recessions?: Using less aggregate price data to identify monetary policy", Federal Reserve Bank of Atlanta , Working Paper with number 98-12.

50. Smal, M. M. and de Jager, S.(2001), "The Monetary Transmission Mechanism in South Africa", South African Reserve Bank, Occasional Paper No. 16, September.

51. Stock James H. and Watson Mark W. (2001), "Vector Auto-regressions", Journal of Economic Perspectives, Volume 15, Number 4, pp. 101-115

52. Svensson, Lars E. O. (1997), "Inflation Forecast Targeting: Implementing and Monitoring Inflation Targets", European Economic Review, Volume 41, Issue 6, pp. 1111-1146, June.

53. The International Monetary Fund, (2006 (a)), "De Facto Classification of Exchange Rate Regimes and Monetary Policy Framework", July. Available at: http://www.imf.org/external/np/mfd/er/2006/eng/0706.htm\#table 
54. The International Monetary Fund, (2006 (b)), "Inflation Targeting and the IMF", Prepared by Monetary and Financial Systems Department, Policy and Development Review Department, and Research Department, March. Available at: http://www.imf.org/external/np/pp/eng/2006/031606.pdf

55. Tuladhar, Anita (2005), "Governance Structures and Decision-Making Roles in Inflation Targeting Central Banks", International Monetary Fund, Working Paper No. 183 , September.

56. Van Der Merwe, E. J. (2004). "Inflation Targeting in South Africa", South African Reserve Bank (SARB), Occasional Paper No. 19, July.

57. Woodford, Michael (2003), "Interest and Prices: Foundations of A Theory of Monetary Policy", Princeton University Press, Princeton, New Jersey, USA. 


\section{$\underline{\operatorname{Appendix}(\mathbf{A}):}$}

\section{Data Issues and Tables}

The data in this paper spans from 1970:Q1 to 2007:Q4.

In all the three countries, the real Gross domestic Product (GDP) series -obtained from the World Development Indicators edited by the World Bank on annual basis - has been used after conversion to quarter frequency to obtain the output gap which was estimated by real GDP minus potential output. On the other hand, inflation rate is measured as a percentage change in the consumer price index. The rate of change in the logarithmic transformation of monetary aggregates and of nominal exchange rate has been computed using Eviews. Those series have been used in VAR and SVAR estimates for the pre-inflation targeting and adoption periods. However, only the logarithmic transformation of monetary aggregate and of nominal exchange rate series have been used to estimate the unrestricted and restricted VAR models to compute the Likelihood Ratio (LR) statistic, which used to check for the possible structural changes due to the adoption of inflation targeting regime.

For South Africa, the time series are obtained from quarterly data available from the International Financial Statistics (IFS) edited by the International Monetary Fund. These variables are: inflation rate, the money market rate, nominal exchange rate, and three definitions of monetary aggregates (i.e. $\mathrm{M}_{1}, \mathrm{M}_{2}, \mathrm{M}_{3}$ ). However, in VAR estimation the most appropriate definition of monetary aggregate was $\mathrm{M}_{3}$ which has been used. The annual growth rate has been used from the World Development Indicators (WDI) database available from the World Bank on annual basis and then transformed into quarterly basis.

For Brazil, the following time series (the money market rate, $\mathrm{M}_{1}, \mathrm{M}_{2}, \mathrm{M}_{3}$, and nominal exchange rate) are from quarterly data available from the International Financial Statistics (IFS). Nevertheless, for the non-availability of a long data series that starts from 1970 for (real Gross Domestic Product and inflation rate). These two series were obtained from different data sources. Annual growth rate was obtained from the World Development Indicators (WDI) database available from the World Bank on annual basis and then transformed into quarterly basis. While, the inflation rate was obtained from the database available from the Brazilian Central Bank and available on monthly basis and transformed into quarterly basis. The transformation of the data frequency has been done through using the econometric package (Eviews). 
For Chile, the following two time series (e.g. inflation rate and nominal exchange rate) are obtained from quarterly data available from the International Financial Statistics (IFS). However, the two definitions of monetary aggregates (e.g. $\mathrm{M}_{1}$ and $\mathrm{M}_{2}$ ) were available also from the (IFS) but on annual basis. Therefore, they have been transformed to quarterly series. Annual growth rate is obtained from the World Development Indicators (WDI) database available from the World Bank on annual basis and then transformed into quarterly basis. Furthermore, I have had to use the average interest rate series as a proxy of monetary policy instrument due to the non-availability of a series of money market rate or any proxy for the short-term interest rate for the period 1970-2007 in (International Financial Statistics (IFS), the World Development Indicators (WDI), the World Economic Outlook (WEO) and even not available at the database of Central Bank of Chile (where most of the data series starts from 1986). The average interest rate series has been obtained from the Global Development Finance database available from the World Bank. In addition, the transformation of the data frequency has been done through using the econometric package (Eviews). 
Table (A-1): Unit Root Tests for the Main

Economic Variables

\begin{tabular}{|c|c|c|}
\hline \multicolumn{3}{|c|}{ South Africa } \\
\hline Variable & $\underline{\text { ADF }}$ & Order of Integration \\
\hline Inflation Rate(infl_sa) & $-10.05232 *$ & $\mathrm{I}(1)$ \\
\hline Monetary Aggregate,log (lm1_sa) & $-12.45971 *$ & $\mathrm{I}(1)$ \\
\hline Monetary Aggregate, $\log \left(\operatorname{lm} 2 \_s a\right)$ & $-10.51292^{*}$ & $\mathrm{I}(1)$ \\
\hline Monetary Aggregate,log $\left(\operatorname{lm} 3 \_s a\right)^{* * * *}$ & $-10.21416^{*}$ & $\mathrm{I}(1)$ \\
\hline Nominal Exchange Rate, $\log (\text { lnom_er_sa })^{* * *}$ & $-9.488191 *$ & $\mathrm{I}(1)$ \\
\hline Output gap(outputgap_sa) & $-5.282480 *$ & $\mathrm{I}(0)$ \\
\hline Money Market Rate $\left(m m r \_s a\right)$ & $-9.211515^{*}$ & $\mathrm{I}(1)$ \\
\hline \multicolumn{3}{|l|}{ Brazil } \\
\hline Variable & $\underline{\text { ADF }}$ & Order of Integration \\
\hline Inflation Rate (infl_br) & $-4.340454 *$ & $\mathrm{I}(0)$ \\
\hline Monetary Aggregate, $\log \left(\operatorname{lm} 1 \_b r\right)^{* * * *}$ & $-3.125327 *$ & $\mathrm{I}(1)$ \\
\hline Monetary Aggregate, $\log \left(\operatorname{lm} 2 \_b r\right)$ & $-4.063851 *$ & $\mathrm{I}(1)$ \\
\hline Monetary Aggregate, $\log \left(\operatorname{lm} 3 \_b r\right)$ & $-4.088987 *$ & $\mathrm{I}(1)$ \\
\hline Nominal Exchange Rate, $\log (\text { lnom_er_br })^{* * *}$ & $-3.435955^{*}$ & $\mathrm{I}(1)$ \\
\hline Output gap(outputgap_br) & $-4.062994 *$ & $\mathrm{I}(0)$ \\
\hline Money Market Rate $\left(m m r \_b r\right)$ & $-8.778164 *$ & $\mathrm{I}(0)$ \\
\hline \multicolumn{3}{|l|}{ Chile } \\
\hline Variable & $\underline{\text { ADF }}$ Statistic & Order of Integration \\
\hline Inflation Rate (infl_ch) & $-7.758265 *$ & $\mathrm{I}(1)$ \\
\hline Monetary Aggregate,log $\left(l m 1 \_c h\right)^{* * * *}$ & $-4.121458 *$ & $\mathrm{I}(0)$ \\
\hline Monetary Aggregate, $\log \left(\operatorname{lm} 2 \_c h\right)$ & $-4.102640 *$ & $\mathrm{I}(0)$ \\
\hline Nominal Exchange Rate, $\log (\text { lnom_er_ch })^{* * *}$ & $-3.995914 *$ & $\mathrm{I}(0)$ \\
\hline Output gap(outputgap_ch) & $-4.389924 *$ & $\mathrm{I}(0)$ \\
\hline Average interest Rate $($ air_ch)** & $-9.134996 *$ & $\mathrm{I}(2)$ \\
\hline
\end{tabular}

Source: calculated using Eviews software.

- Unit root tests have been performed on variables expressed as logs, except the inflation rate, the money market rate, and the average interest rate.

-The lag length is chosen to minimize the Schwarz information criterion.

(*) Denotes significance at 5\% level according to the Augmented Dickey Fuller distribution's critical values.

(**) For Chile, I had to use the average interest rate series as a proxy of monetary policy instrument due to the non-availability of a series of money market rate for such a long period that spans from 1970.

(***) The rate of change in the logarithmic transformation of monetary aggregates and of nominal exchange rate has been computed and tested for stationarity. As expected in all countries it has been integrated of order zero. Those series have been used in VAR and SVAR estimates. However, only the logarithmic transformation of monetary aggregate and of nominal exchange have been used to estimate the unrestricted and restricted VAR models to compute the likelihood ratio statistic. 
Table (A-2): Inflation Targeting Regime in Brazil

\begin{tabular}{|c|c|c|c|c|c|c|}
\hline Year & Regulation & Date & $\frac{\text { Target }}{\underline{(\%)}}$ & $\frac{\text { Tolerance }}{\text { Intervals }}$ & $\frac{\text { Upper and }}{\text { Lower }}$ & $\frac{\text { Actual }}{\frac{\text { Inflation }}{\text { IPCA\%) }}}$ \\
\hline 1999 & & & 8 & 2 & $6-10$ & 8.94 \\
\hline 2000 & Resolution 2,615 & $30 / 6 / 1999$ & 6 & 2 & $4-8$ & 5.97 \\
\hline 2001 & & & 4 & 2 & $2-6$ & 7.67 \\
\hline 2002 & Resolution 2,744 & $28 / 6 / 2000$ & 3.5 & 2 & $1.5-5.5$ & 12.53 \\
\hline $2003 *$ & $\begin{array}{ll}\text { Resolution } & 2,842 \\
\text { Resolution } & 2,972\end{array}$ & $\begin{array}{l}28 / 6 / 2001 \\
27 / 6 / 2002\end{array}$ & $\begin{array}{c}3.25 \\
4\end{array}$ & $\begin{array}{c}2 \\
2.5\end{array}$ & $\begin{array}{c}1.25-5.25 \\
1.5-6.5\end{array}$ & 9.30 \\
\hline $2004 *$ & $\begin{array}{ll}\text { Resolution } & 2,972 \\
\text { Resolution } & 3,108\end{array}$ & $\begin{array}{l}27 / 6 / 2002 \\
25 / 6 / 2003\end{array}$ & $\begin{array}{c}3.75 \\
5.5\end{array}$ & $\begin{array}{l}2.5 \\
2.5\end{array}$ & $\begin{array}{c}1.25-6.25 \\
3-8\end{array}$ & 7.60 \\
\hline 2005 & Resolution 3,108 & $25 / 6 / 2003$ & 4.5 & 2.5 & $2-7$ & 5.69 \\
\hline 2006 & Resolution 3,210 & $30 / 6 / 2004$ & 4.5 & 2 & $2.5-6.5$ & 3.14 \\
\hline 2007 & Resolution 3,291 & $23 / 6 / 2005$ & 4.5 & 2 & $2.5-6.5$ & 4.46 \\
\hline 2008 & Resolution 3,378 & $29 / 6 / 2006$ & 4.5 & 2 & $2.5-6.5$ & $N A$ \\
\hline 2009 & Resolution 3,463 & $26 / 6 / 2007$ & 4.5 & 2 & $2.5-6.5$ & $N A$ \\
\hline
\end{tabular}

Source: The Brazilian Central Bank. Available at: http://www.bcb.gov.br/pec/metas/InflationTargetingTable.pdf

* The open letter of 21/1/2003 adjusted the targets to $8.5 \%$ for 2003 and $5.5 \%$ for 2004 . 
Table (A-3): South Africa: Accumulated Response to Structural One S.D. Innovations Obtained from the SVAR estimates for the Pre-Inflation Targeting Period

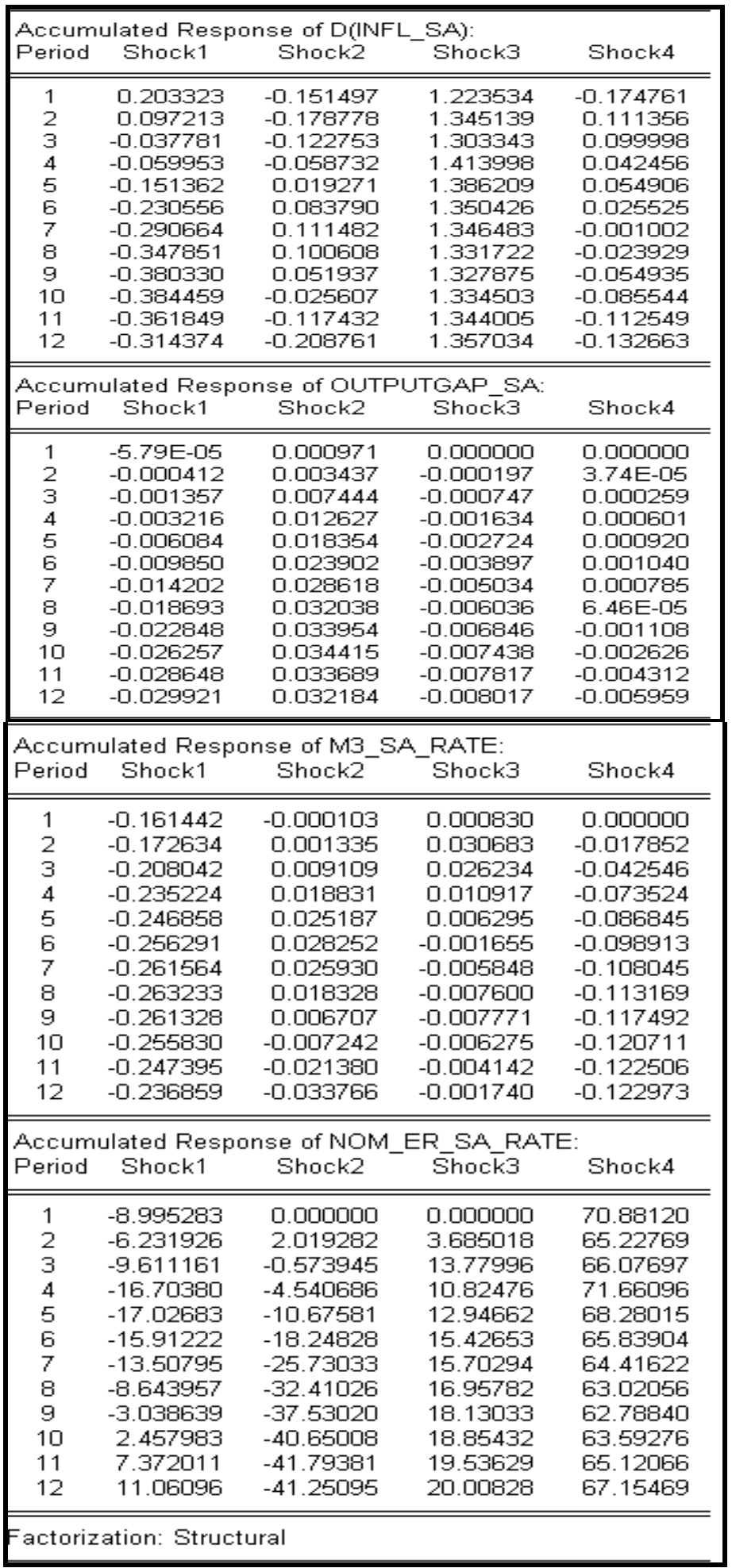


Table (A-4): South Africa: Accumulated Response to Structural One S.D. Innovations Obtained from the SVAR Estimates for the Inflation Targeting Period

\begin{tabular}{|c|c|c|c|c|}
\hline \multicolumn{5}{|c|}{ Accumulated Response of D(INFL_SA): } \\
\hline Period & Shock1 & Shock2 & Shock3 & Shock4 \\
\hline 1 & -0.589750 & 0.186540 & 0.547820 & 0.0069 \\
\hline 2 & -0.859932 & 0.588103 & 0.518125 & \\
\hline 3 & -0.796060 & 0.939855 & 0.47 & \\
\hline 4 & -0.768049 & 1.098410 & 0.221122 & \\
\hline 5 & -0.406165 & 1.099616 & -0.049662 & \\
\hline 6 & -0.0 & 0.96 & -0.233 & \\
\hline 7 & 0.166366 & 0.853168 & -0.346061 & 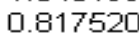 \\
\hline 8 & 0.210370 & 0.862791 & -0.388958 & \\
\hline 9 & 0.0 & 1.0 & -0.352 & \\
\hline 10 & -0.076638 & 1.287952 & -0.324317 & \\
\hline 11 & -0.192615 & 1.556148 & -0.353468 & 0.001 \\
\hline 12 & -0.218807 & 1.734739 & -0.447476 & 0.035 \\
\hline
\end{tabular}

\begin{tabular}{ccccc}
\multicolumn{5}{c}{ Accumulated Response of OUTPUTGAP_SA: } \\
Period & Shock1 & Shock2 & Shock3 & Shock4 \\
\hline 1 & $-7.60 E-05$ & 0.000287 & 0.000000 & 0.000000 \\
2 & -0.000183 & 0.000972 & -0.000107 & $8.38 E-05$ \\
3 & -0.000206 & 0.002011 & -0.000391 & 0.000258 \\
4 & $-3.40 E-05$ & 0.003238 & -0.000959 & 0.000482 \\
5 & 0.000402 & 0.004470 & -0.001789 & 0.000576 \\
6 & 0.001050 & 0.005579 & -0.002776 & 0.000403 \\
7 & 0.001788 & 0.006537 & -0.003783 & -0.000150 \\
8 & 0.002448 & 0.007398 & -0.004702 & -0.001092 \\
9 & 0.002891 & 0.008253 & -0.005471 & -0.002298 \\
10 & 0.003073 & 0.009170 & -0.006081 & -0.003584 \\
11 & 0.003042 & 0.010152 & -0.006563 & -0.004790 \\
12 & 0.002902 & 0.011142 & -0.006976 & -0.005815 \\
\hline Accumulated Response of D(MMR_SA): & \\
Period & Shock1 & Shock2 & - Shock3 & Shock4 \\
\hline 1 & -0.423978 & 0.000167 & 0.000491 & 0.000000 \\
2 & -0.606828 & 0.202028 & 0.135320 & 0.081441 \\
3 & -0.608425 & 0.384823 & 0.272596 & 0.199373 \\
4 & -0.569954 & 0.482530 & 0.199489 & 0.373824 \\
5 & -0.483878 & 0.520727 & -0.023235 & 0.515305 \\
6 & -0.360249 & 0.541142 & -0.148659 & 0.594388 \\
7 & -0.211215 & 0.570574 & -0.184764 & 0.570523 \\
8 & -0.093929 & 0.632056 & -0.239368 & 0.390697 \\
9 & -0.083467 & 0.752660 & -0.340479 & 0.223600 \\
10 & -0.126083 & 0.935866 & -0.427171 & 0.142020 \\
11 & -0.138440 & 1.136970 & -0.480476 & 0.070469 \\
12 & -0.107955 & 1.303903 & -0.553320 & -0.020316 \\
\hline Accumulated Response of NOM_ER_SA_RATE: \\
Period & Shock1 & Shock2 & Shock3 & Shock4 \\
\hline 1 & -0.799367 & 0.000000 & 0.000000 & 3.095428 \\
2 & -0.028171 & 0.016612 & 0.020395 & 4.061163 \\
3 & 0.858221 & -0.194296 & -0.057543 & 3.765985 \\
4 & 1.265483 & -0.336003 & -0.610234 & 4.340836 \\
5 & 1.653503 & -0.308899 & -1.067890 & 4.353486 \\
6 & 1.884129 & -0.105127 & -1.124132 & 3.924664 \\
7 & 2.010633 & 0.234649 & -1.180053 & 3.561457 \\
8 & 2.057380 & 0.564756 & -1.405920 & 3.113945 \\
9 & 1.986281 & 0.803007 & -1.662053 & 2.833578 \\
10 & 1.969615 & 0.899694 & -1.780385 & 2.665034 \\
11 & 2.034879 & 0.805876 & -1.758038 & 2.365527 \\
12 & 2.034721 & 0.563516 & -1.694574 & 2.021451 \\
\hline
\end{tabular}

Factorization: Structural 
Table (A-5): Brazil: Accumulated Response to Structural One S.D. Innovations Obtained from the SVAR Estimates for the Pre-Inflation Targeting Period

\begin{tabular}{|c|c|c|c|c|}
\hline \multicolumn{5}{|c|}{ Accumulated Response of INFL_BR: } \\
\hline $\begin{array}{c}1 \\
2 \\
3 \\
4 \\
5 \\
6 \\
7 \\
8 \\
9 \\
10 \\
11 \\
12\end{array}$ & $\begin{array}{l}-0.644461 \\
-2.197363 \\
-3.613179 \\
-4.122271 \\
-4.797375 \\
-5.495578 \\
-6.294363 \\
-6.941003 \\
-7.592154 \\
-8.124452 \\
-8.465120 \\
-8.603376\end{array}$ & $\begin{array}{l}-0.744560 \\
-2.028677 \\
-2.358467 \\
-1.743880 \\
-0.971744 \\
-0.687257 \\
-0.851277 \\
-1.407728 \\
-2.224782 \\
-3.020252 \\
-3.473749 \\
-3.437865\end{array}$ & $\begin{array}{l}8.027838 \\
12.94641 \\
16.52399 \\
19.17423 \\
22.97709 \\
25.82006 \\
27.71928 \\
29.41882 \\
31.10522 \\
32.62658 \\
33.73524 \\
34.63796\end{array}$ & $\begin{array}{l}0.094386 \\
0.422961 \\
1.018436 \\
1.880166 \\
2.813385 \\
3.274412 \\
3.665047 \\
4.087351 \\
4.560985 \\
4.968608 \\
5.359964 \\
5.733913\end{array}$ \\
\hline \multicolumn{5}{|c|}{ Accumulated Response of OUTPUTGAP_BR: } \\
\hline $\begin{array}{c}1 \\
2 \\
3 \\
4 \\
5 \\
6 \\
7 \\
8 \\
9 \\
10 \\
11 \\
12\end{array}$ & $\begin{array}{r}0.000326 \\
0.001112 \\
0.002302 \\
0.003680 \\
0.004799 \\
0.005245 \\
0.004838 \\
0.003690 \\
0.002100 \\
0.000432 \\
-0.001010 \\
-0.002064\end{array}$ & $\begin{array}{l}0.001584 \\
0.006283 \\
0.014561 \\
0.025615 \\
0.037776 \\
0.049176 \\
0.058401 \\
0.064814 \\
0.068544 \\
0.070208 \\
0.070546 \\
0.070120\end{array}$ & $\begin{array}{r}0.000000 \\
-2.52 \mathrm{E}-05 \\
-0.000162 \\
-0.000577 \\
-0.001187 \\
-0.001818 \\
-0.002253 \\
-0.002294 \\
-0.001918 \\
-0.001304 \\
-0.000725 \\
-0.000401\end{array}$ & $\begin{array}{r}0.000000 \\
-0.000149 \\
-0.000720 \\
-0.001918 \\
-0.003829 \\
-0.006357 \\
-0.009236 \\
-0.012142 \\
-0.014780 \\
-0.016956 \\
-0.018590 \\
-0.019702\end{array}$ \\
\hline \multicolumn{5}{|c|}{$\begin{array}{l}\text { Accumulated Response of M1_BR_RATE: } \\
\text { Period Shock1 Shock2 }\end{array}$} \\
\hline $\begin{array}{c}1 \\
2 \\
3 \\
4 \\
5 \\
6 \\
7 \\
8 \\
9 \\
10 \\
11 \\
12\end{array}$ & $\begin{array}{l}-30.79251 \\
-30.77135 \\
-30.16672 \\
-30.28406 \\
-31.63984 \\
-29.71027 \\
-27.36158 \\
-28.00658 \\
-28.18594 \\
-27.82652 \\
-26.37646 \\
-25.08753\end{array}$ & $\begin{array}{r}-0.002887 \\
0.441787 \\
1.769157 \\
1.473302 \\
1.930224 \\
3.816864 \\
2.471774 \\
-2.778236 \\
-9.355879 \\
-14.17766 \\
-16.86418 \\
-17.55891\end{array}$ & $\begin{array}{r}0.031124 \\
-0.622247 \\
5.062735 \\
18.95994 \\
3.863823 \\
-5.031174 \\
-10.15665 \\
-9.625653 \\
-14.60297 \\
-18.56213 \\
-20.50888 \\
-21.98999\end{array}$ & $\begin{array}{r}0.000000 \\
-0.961723 \\
-1.071385 \\
-4.802413 \\
-7.122065 \\
-6.947863 \\
-6.748914 \\
-7.470381 \\
-8.776798 \\
-8.413097 \\
-7.623023 \\
-6.961576\end{array}$ \\
\hline $\begin{array}{l}\text { Accum } \\
\text { Period }\end{array}$ & $\begin{array}{l}\text { lated Resp } \\
\text { Shock1 }\end{array}$ & $\begin{array}{l}\text { se of NOM1 } \\
\text { Shock2 }\end{array}$ & $\begin{array}{l}\text { ER_BR_RAT } \\
\text { Shock3 }\end{array}$ & Shock 4 \\
\hline $\begin{array}{l}1 \\
2 \\
3 \\
4 \\
5 \\
6 \\
7 \\
8 \\
9 \\
10 \\
11 \\
12\end{array}$ & $\begin{array}{l}3.649842 \\
5.054036 \\
5.290612 \\
6.055841 \\
6.817118 \\
7.659662 \\
8.209804 \\
8.728098 \\
9.435792 \\
10.16250 \\
10.83940 \\
11.30453\end{array}$ & $\begin{array}{r}0.000000 \\
-1.094366 \\
-0.415011 \\
-0.797459 \\
-1.928803 \\
-3.054114 \\
-3.849588 \\
-4.076403 \\
-3.431530 \\
-1.877414 \\
0.208562 \\
2.378191\end{array}$ & $\begin{array}{r}0.000000 \\
-6.696906 \\
-7.476643 \\
-7.520151 \\
-10.69670 \\
-13.38290 \\
-15.42714 \\
-16.59015 \\
-18.04597 \\
-19.10631 \\
-20.14131 \\
-21.04116\end{array}$ & $\begin{array}{l}51.33483 \\
51.27480 \\
51.61553 \\
52.62596 \\
54.40682 \\
54.11380 \\
54.21478 \\
54.32156 \\
54.24327 \\
54.03384 \\
53.70961 \\
53.26641\end{array}$ \\
\hline
\end{tabular}


Table (A-6): Brazil: Accumulated Response to Structural One S.D. Innovations Obtained from the SVAR Estimates for the Inflation Targeting Period

\begin{tabular}{|c|c|c|c|c|}
\hline \multicolumn{4}{|c|}{ Accumulated Response of INFL_BR: } & Shock4 \\
\hline $\begin{array}{l}1 \\
2 \\
3 \\
4 \\
5 \\
6 \\
7 \\
8 \\
9 \\
10 \\
11 \\
12\end{array}$ & $\begin{array}{l}-0.095935 \\
-0.215545 \\
-0.292922 \\
-0.334158 \\
-0.366591 \\
-0.405559 \\
-0.451848 \\
-0.502168 \\
-0.555502 \\
-0.611534 \\
-0.667446 \\
-0.718247\end{array}$ & $\begin{array}{r}-0.010330 \\
0.017284 \\
0.061595 \\
0.090614 \\
0.094199 \\
0.083605 \\
0.073636 \\
0.071041 \\
0.075443 \\
0.084770 \\
0.097634 \\
0.112387\end{array}$ & $\begin{array}{l}0.276584 \\
0.271867 \\
0.140435 \\
0.064062 \\
0.077419 \\
0.117960 \\
0.131585 \\
0.117553 \\
0.101565 \\
0.097747 \\
0.100651 \\
0.099977\end{array}$ & $\begin{array}{r}-0.063525 \\
0.146557 \\
0.339833 \\
0.385790 \\
0.355565 \\
0.348630 \\
0.391141 \\
0.451985 \\
0.501790 \\
0.538928 \\
0.575211 \\
0.615497\end{array}$ \\
\hline \multicolumn{4}{|c|}{ Accumulated Response of OUTPUTGAP_BR: } & Shock4 \\
\hline $\begin{array}{l}1 \\
2 \\
3 \\
4 \\
5 \\
6 \\
7 \\
8 \\
9 \\
10 \\
11 \\
12\end{array}$ & $\begin{array}{l}0.000156 \\
0.000868 \\
0.002501 \\
0.005074 \\
0.008240 \\
0.011457 \\
0.014204 \\
0.016164 \\
0.017298 \\
0.017827 \\
0.018110 \\
0.018514\end{array}$ & $\begin{array}{r}0.000865 \\
0.002053 \\
0.003012 \\
0.003345 \\
0.002932 \\
0.001925 \\
0.000666 \\
-0.000460 \\
-0.001166 \\
-0.001343 \\
-0.001077 \\
-0.000585\end{array}$ & $\begin{array}{r}0.000000 \\
-8.686-05 \\
-0.000338 \\
-0.000600 \\
-0.000706 \\
-0.000568 \\
-0.000216 \\
0.000242 \\
0.000674 \\
0.000982 \\
0.001122 \\
0.001110\end{array}$ & $\begin{array}{r}0.000000 \\
-0.000419 \\
-0.001429 \\
-0.003171 \\
-0.005509 \\
-0.008072 \\
-0.010414 \\
-0.012201 \\
-0.013318 \\
-0.013874 \\
-0.014130 \\
-0.014383\end{array}$ \\
\hline \multicolumn{4}{|c|}{$\begin{array}{l}\text { A.ccumulated Response of MMR_BR: } \\
\text { Period Shock1 Shock2 Shock3 }\end{array}$} & Shock4 \\
\hline $\begin{array}{l}1 \\
2 \\
3 \\
4 \\
5 \\
6 \\
7 \\
8 \\
9 \\
10 \\
11 \\
12\end{array}$ & $\begin{array}{l}-1.042458 \\
-2.512763 \\
-4.146183 \\
-5.677050 \\
-6.921776 \\
-7.851353 \\
-8.541636 \\
-9.100803 \\
-9.629970 \\
-10.20781 \\
-10.87736 \\
-11.63438\end{array}$ & $\begin{array}{r}-0.000501 \\
0.054909 \\
0.294239 \\
0.719633 \\
1.195926 \\
1.568306 \\
1.760508 \\
1.788840 \\
1.721607 \\
1.636252 \\
1.595766 \\
1.637960\end{array}$ & $\begin{array}{l}0.013418 \\
0.507458 \\
0.887615 \\
0.752790 \\
0.350261 \\
0.040801 \\
-0.070972 \\
-0.086744 \\
-0.109637 \\
-0.151964 \\
-0.182134 \\
-0.192547\end{array}$ & $\begin{array}{l}0.000000 \\
0.397530 \\
1.473583 \\
2.967601 \\
4.270019 \\
5.099980 \\
5.590754 \\
5.986791 \\
6.417058 \\
6.894632 \\
7.409445 \\
7.968804\end{array}$ \\
\hline \multicolumn{5}{|c|}{$\begin{array}{l}\text { Accumulated Response of NOM_ER_BR_RATE: } \\
\text { Period Shock1 } \quad \text { Shock2 }\end{array}$} \\
\hline $\begin{array}{c}1 \\
2 \\
3 \\
4 \\
5 \\
6 \\
7 \\
8 \\
9 \\
10 \\
11 \\
12\end{array}$ & $\begin{array}{l}-1.429493 \\
-2.416533 \\
-2.781352 \\
-2.913998 \\
-3.230679 \\
-3.726693 \\
-4.247352 \\
-4.752372 \\
-5.303210 \\
-5.928105 \\
-6.565591 \\
-7.119179\end{array}$ & $\begin{array}{l}0.000000 \\
0.810908 \\
1.582342 \\
1.790586 \\
1.591421 \\
1.353818 \\
1.259856 \\
1.280899 \\
1.347028 \\
1.446338 \\
1.595636 \\
1.781126\end{array}$ & $\begin{array}{r}0.000000 \\
-2.629658 \\
-5.323192 \\
-5.368433 \\
-4.083970 \\
-3.379219 \\
-3.641219 \\
-4.150959 \\
-4.315283 \\
-4.167875 \\
-4.034095 \\
-4.082984\end{array}$ & $\begin{array}{l}6.396768 \\
10.93054 \\
12.35336 \\
11.02963 \\
9.857791 \\
10.16470 \\
11.23341 \\
12.03225 \\
12.34532 \\
12.55578 \\
12.96112 \\
13.50129\end{array}$ \\
\hline
\end{tabular}


Table (A-7): Chile: Accumulated Response to Structural One S.D. Innovations Obtained from the SVAR Estimates for The Pre-Inflation Targeting Period

\begin{tabular}{|c|c|c|c|c|}
\hline $\begin{array}{l}\text { Accum } \\
\text { Period }\end{array}$ & $\begin{array}{l}\text { ulated Resp } \\
\text { Shock1 }\end{array}$ & $\begin{array}{c}\text { nse of D(INF } \\
\text { Shock2 }\end{array}$ & $\begin{array}{l}-(\mathrm{CH}): \\
\text { Shock3 }\end{array}$ & Shock4 \\
\hline 1 & 2.533170 & 4.350729 & 4.549766 & 7.088970 \\
\hline 2 & 8.014407 & 3.246436 & 0.519158 & 11.44934 \\
\hline 3 & 5.420567 & 0.846289 & 0.233822 & 15.87100 \\
\hline 4 & 3.871999 & 1.462504 & -2.263496 & 19.57475 \\
\hline 5 & 3.629362 & -0.672713 & -7.177184 & 12.68540 \\
\hline 6 & 0.206103 & 0.568584 & -4.165768 & 11.22631 \\
\hline 7 & 0.830196 & 5.222230 & -1.984905 & 10.17515 \\
\hline 8 & -0.267369 & 4.866311 & -0.415554 & 9.381946 \\
\hline 9 & -3.657651 & 2.448656 & -3.331060 & 11.70222 \\
\hline 10 & -6.267658 & 5.604725 & -4.030237 & 10.70670 \\
\hline 11 & -8.157516 & 7.585890 & -3.634031 & 10.10100 \\
\hline 12 & -10.71190 & 7.343122 & -3.791454 & 9.788586 \\
\hline \multicolumn{5}{|c|}{ Accumulated Response of OUTPUTGAP_CH: } \\
\hline Period & Shock1 & Shock2 & Shock 3 & Shock 4 \\
\hline 1 & -0.000806 & 0.001465 & 0.000000 & 0.000000 \\
\hline 2 & -0.003274 & 0.005154 & $6.51 \mathrm{E}-05$ & 0.001354 \\
\hline 3 & -0.008086 & 0.012022 & $-6.76 E-05$ & 0.005488 \\
\hline 4 & -0.015491 & 0.022333 & -0.000726 & 0.012777 \\
\hline 5 & -0.024653 & 0.034861 & -0.002168 & 0.022619 \\
\hline 6 & -0.034221 & 0.047755 & -0.004607 & 0.033083 \\
\hline 7 & -0.042876 & 0.058942 & -0.007660 & 0.041703 \\
\hline 8 & -0.049399 & 0.067052 & -0.010620 & 0.046731 \\
\hline 9 & -0.052954 & 0.070901 & -0.012960 & 0.047704 \\
\hline 10 & -0.053333 & 0.070877 & -0.014125 & 0.044939 \\
\hline 11 & -0.050573 & 0.067568 & -0.014080 & 0.039442 \\
\hline 12 & -0.045368 & 0.061740 & -0.013098 & 0.032696 \\
\hline \multicolumn{5}{|c|}{ Accumulated Response of M1_CH_RATE: } \\
\hline perio & Shock 1 & Shock 2 & Shocks & Shock4 \\
\hline 1 & -11.90758 & ㅁ. 827149 & ㅁ.864990 & 0.000000 \\
\hline 2 & -12.25551 & 8.321062 & 4.213266 & 3.831978 \\
\hline 3 & -9.344479 & 8. 403882 & -2.286459 & 5.696605 \\
\hline 4 & -16.68193 & 8.118425 & -2.612651 & 7.627081 \\
\hline 5 & -19.77918 & 15.85835 & 2.017784 & 10.82159 \\
\hline 6 & -21.74521 & 4.653351 & -14.84741 & -3.128172 \\
\hline 7 & -34.11050 & 7.926689 & -6.095045 & -7.482190 \\
\hline 8 & -29.55725 & 18.07546 & -3.905958 & -12.73438 \\
\hline 9 & -32.09930 & 16.40344 & 1.387784 & -20.03334 \\
\hline 10 & -33.92236 & 13.06558 & 1.025438 & -10.84944 \\
\hline 11 & -32.22876 & 15.44813 & -2.659050 & -13.38641 \\
\hline 12 & -31.77210 & 12.96704 & ‥109676 & -11.83996 \\
\hline \multicolumn{5}{|c|}{ Accumulated Response of NOM_ER_CH_RATE } \\
\hline 1 & -20.27738 & 0.000000 & 0.000000 & 1.209908 \\
\hline 2 & -20.55419 & 16.00250 & 8.096443 & 9.461916 \\
\hline 3 & -14.57679 & 14.55448 & -4.966801 & 12. 44424 \\
\hline 4 & -28.61890 & 13. 15312 & -5.372204 & 15.03206 \\
\hline 5 & -37.24275 & 25.27341 & 0.408877 & 20.02453 \\
\hline 6 & -41.21539 & 10.13085 & -25.83215 & -5.878066 \\
\hline 7 & -60.62073 & 16.45093 & -10.50492 & -11.51133 \\
\hline 8 & -54.51344 & 34.14248 & -7.535583 & -19.66638 \\
\hline 9 & -61.35447 & 31.90163 & 2.767316 & -28.77376 \\
\hline 10 & -64.86924 & 25.02752 & -3.341142 & -16.36017 \\
\hline 11 & -64.90263 & 30.53624 & -7.462296 & -21.73805 \\
\hline 12 & -63.15834 & 29.06304 & -2.332109 & -19.50410 \\
\hline
\end{tabular}


Table (A-8): Chile: Accumulated Response to Structural One S.D. Innovations Obtained from the SVAR Estimates for the Inflation Targeting Period

\begin{tabular}{|c|c|c|c|c|}
\hline \multicolumn{5}{|c|}{ Accumulated Response of $\mathrm{D}(\mathrm{INFL} C \mathrm{CH})$ : } \\
\hline $\begin{array}{c}1 \\
2 \\
3 \\
4 \\
5 \\
6 \\
7 \\
8 \\
9 \\
10 \\
11 \\
12\end{array}$ & $\begin{array}{l}-0.311419 \\
-0.388552 \\
-0.420280 \\
-0.362158 \\
-0.267122 \\
-0.232794 \\
-0.246217 \\
-0.371133 \\
-0.421367 \\
-0.458771 \\
-0.456987 \\
-0.329095\end{array}$ & $\begin{array}{l}-0.430711 \\
-0.468375 \\
-0.520960 \\
-0.655637 \\
-0.452494 \\
-0.372805 \\
-0.303562 \\
-0.146782 \\
-0.163460 \\
-0.195296 \\
-0.225175 \\
-0.313302\end{array}$ & $\begin{array}{l}0.968234 \\
1.087100 \\
1.252243 \\
1.560960 \\
1.289435 \\
1.255090 \\
1.221783 \\
1.022555 \\
1.043634 \\
1.027876 \\
0.971810 \\
0.986408\end{array}$ & $\begin{array}{l}0.070874 \\
-0.151347 \\
-0.250217 \\
-0.494549 \\
-0.699144 \\
-0.751452 \\
-0.892108 \\
-0.948587 \\
-0.951074 \\
-0.996118 \\
-0.975477 \\
-0.978090\end{array}$ \\
\hline \multicolumn{4}{|c|}{ Accumulated Response of OUTPUTGAP_CH: } & Shock 4 \\
\hline $\begin{array}{c}1 \\
2 \\
3 \\
4 \\
5 \\
6 \\
7 \\
8 \\
9 \\
10 \\
11 \\
12\end{array}$ & $\begin{array}{l}-0.000414 \\
-0.001306 \\
-0.002532 \\
-0.003962 \\
-0.005483 \\
-0.007091 \\
-0.008733 \\
-0.010241 \\
-0.011415 \\
-0.012024 \\
-0.011989 \\
-0.011430\end{array}$ & $\begin{array}{l}0.000983 \\
0.003421 \\
0.007342 \\
0.012389 \\
0.017979 \\
0.023428 \\
0.028059 \\
0.031377 \\
0.033146 \\
0.033446 \\
0.032639 \\
0.031249\end{array}$ & $\begin{array}{r}0.000000 \\
0.000155 \\
0.000494 \\
0.000980 \\
0.001459 \\
0.001751 \\
0.001739 \\
0.001348 \\
0.000615 \\
-0.000367 \\
-0.001456 \\
-0.002467\end{array}$ & $\begin{array}{c}0.000000 \\
-6.01 \mathrm{E}-05 \\
-0.000301 \\
-0.000813 \\
-0.001630 \\
-0.002699 \\
-0.003903 \\
-0.005109 \\
-0.006142 \\
-0.006862 \\
-0.007194 \\
-0.007130\end{array}$ \\
\hline \multicolumn{5}{|c|}{ Accumulated Response of D(INTERST_CHILE,2): } \\
\hline $\begin{array}{c}1 \\
2 \\
3 \\
4 \\
5 \\
6 \\
7 \\
8 \\
9 \\
10 \\
11 \\
12\end{array}$ & $\begin{array}{r}-0.416630 \\
-0.324340 \\
-0.286547 \\
-0.289144 \\
0.056001 \\
-0.047540 \\
-0.070003 \\
-0.086199 \\
-0.339162 \\
-0.255383 \\
-0.255929 \\
-0.235192\end{array}$ & $\begin{array}{r}-0.000788 \\
-0.048088 \\
-0.115003 \\
-0.159171 \\
-0.124710 \\
-0.099385 \\
-0.014576 \\
0.068515 \\
0.031070 \\
0.048237 \\
0.007707 \\
-0.063911\end{array}$ & $\begin{array}{r}0.001771 \\
-0.075421 \\
-0.066728 \\
-0.024877 \\
-0.179720 \\
-0.077665 \\
-0.100558 \\
-0.157826 \\
0.019707 \\
-0.073610 \\
-0.052121 \\
0.011115\end{array}$ & $\begin{array}{r}0.000000 \\
-0.033478 \\
-0.084919 \\
0.017455 \\
-0.017718 \\
0.012870 \\
0.033092 \\
0.013588 \\
0.049045 \\
-0.005910 \\
-0.009940 \\
0.005509\end{array}$ \\
\hline $\begin{array}{l}\text { Accum } \\
\text { Period }\end{array}$ & $\begin{array}{l}\text { lated Res } \\
\text { Shock1 }\end{array}$ & $\begin{array}{c}\text { se of NOl } \\
\text { Shock2 }\end{array}$ & Sh_CH_R & Shock4 \\
\hline $\begin{array}{c}1 \\
2 \\
3 \\
4 \\
5 \\
6 \\
7 \\
8 \\
9 \\
10 \\
11 \\
12\end{array}$ & $\begin{array}{r}-0.043531 \\
0.002831 \\
0.014987 \\
0.060444 \\
0.071756 \\
0.064823 \\
0.039809 \\
-0.014319 \\
-0.059021 \\
-0.076989 \\
-0.075874 \\
-0.062015\end{array}$ & $\begin{array}{r}0.000000 \\
-0.125582 \\
-0.153262 \\
-0.076497 \\
-0.045016 \\
-0.032698 \\
0.042832 \\
0.108215 \\
0.148105 \\
0.164391 \\
0.165145 \\
0.177267\end{array}$ & $\begin{array}{r}0.000000 \\
-0.031810 \\
-0.015644 \\
-0.048254 \\
0.019940 \\
0.079261 \\
0.079317 \\
0.125025 \\
0.152812 \\
0.147707 \\
0.149477 \\
0.126009\end{array}$ & $\begin{array}{l}0.572804 \\
0.719140 \\
0.674871 \\
0.727580 \\
0.944946 \\
1.003396 \\
0.959275 \\
0.962576 \\
1.001945 \\
1.000786 \\
0.966437 \\
0.953873\end{array}$ \\
\hline
\end{tabular}


Appendix (B):

Figures

Figure (B-B1): South Africa: Impulse response From VAR for the Pre-Inflation Targeting Period

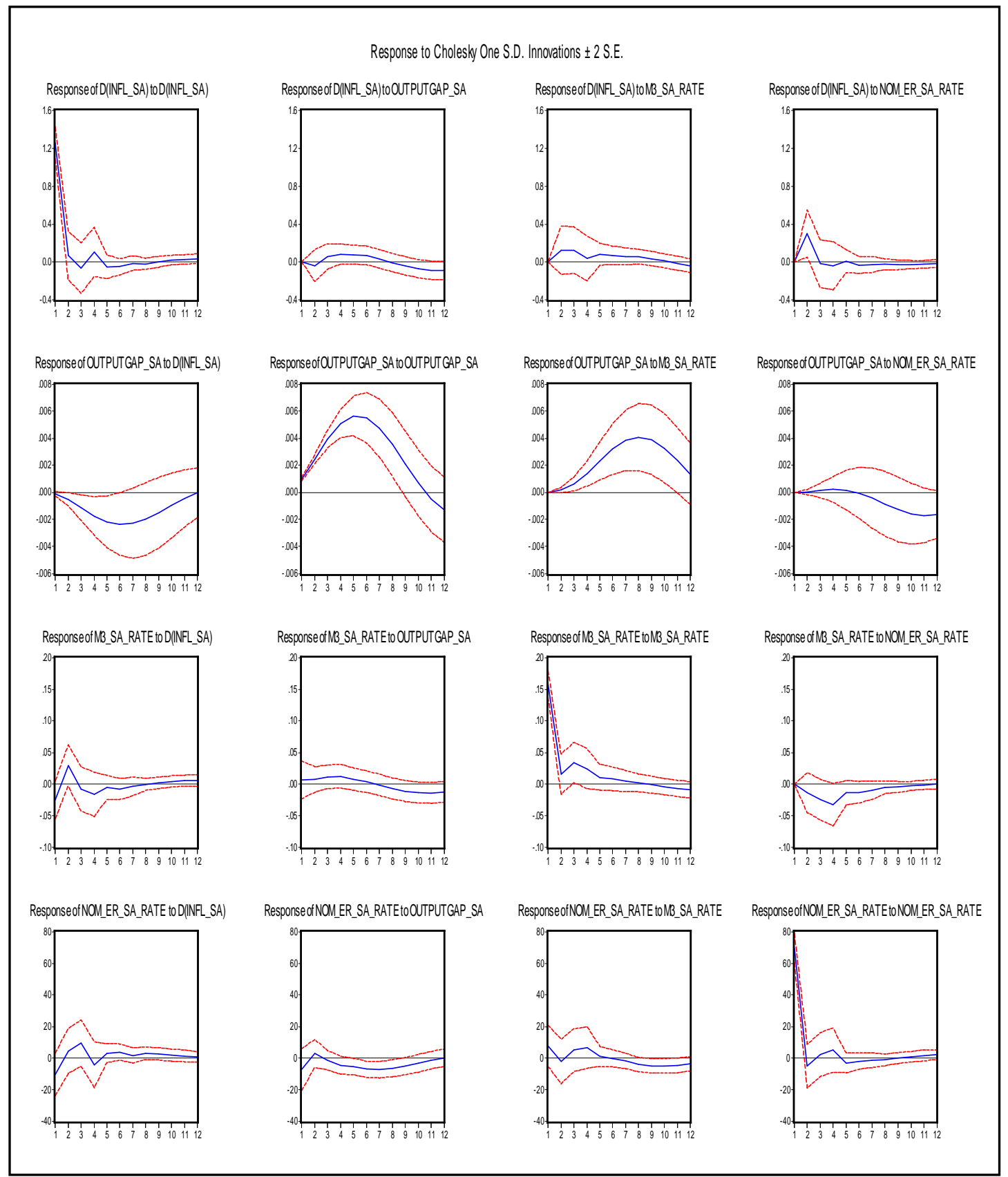

Note: The sample spans from 1970:Q1 to 1999:Q4, indicating the pre-inflation targeting period. The variables used in this VAR were four variables. The first difference of inflation rate (infl_sa), output gap (outputgap_sa), the percentage change of the log transformation of monetary aggregate ( $\mathrm{m3}_{-}$sa_rate), and the percentage change of the log transformation of nominal exchange rate (nom_er_sa_rate). The lag length was 3 lags depending on Schwarz Information Criterion (SC). 
Figure (B-B2): South Africa: Impulse response From VAR for the Inflation Targeting Period

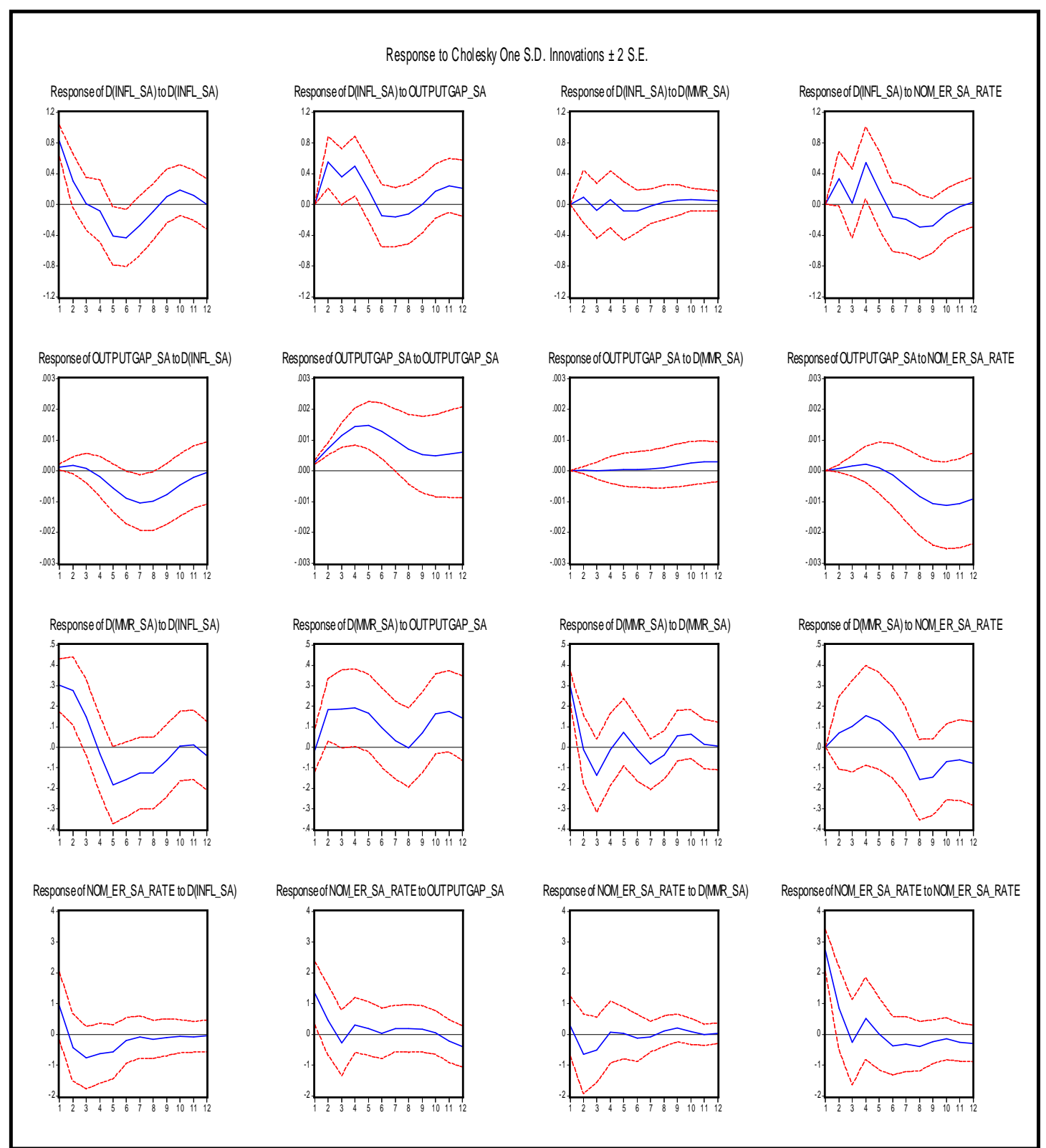

Note: Sample Spans from 2000:Q1 to 2007:Q4, indicating the period of inflation targeting adoption. Using the variables d(infl_sa), (outputgap_sa), But, this time instead of monetary aggregate series, I used the first difference of the money market rate $d\left(m_{m} r_{-} s a\right)$ and finally (nom_er_sa_rate). Depending on more conservative Schwartz information (SC) criterion, I have used lag of three. 
Figure (B-B3): South Africa : Impulse response from SVAR Covers the Pre-Inflation Targeting Period

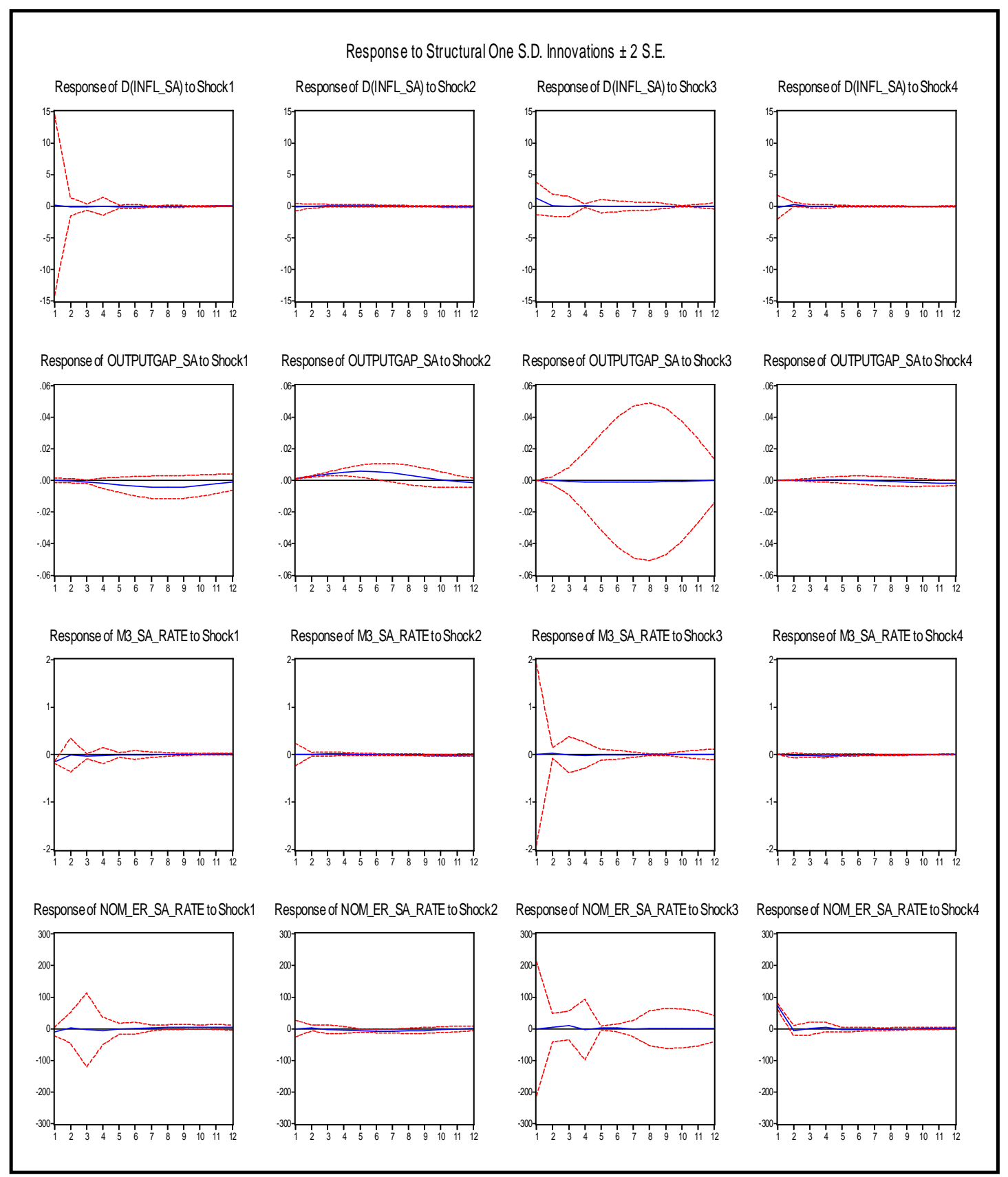


Figure (B-B4): South Africa: Impulse Response From SVAR in the Inflation Targeting Period

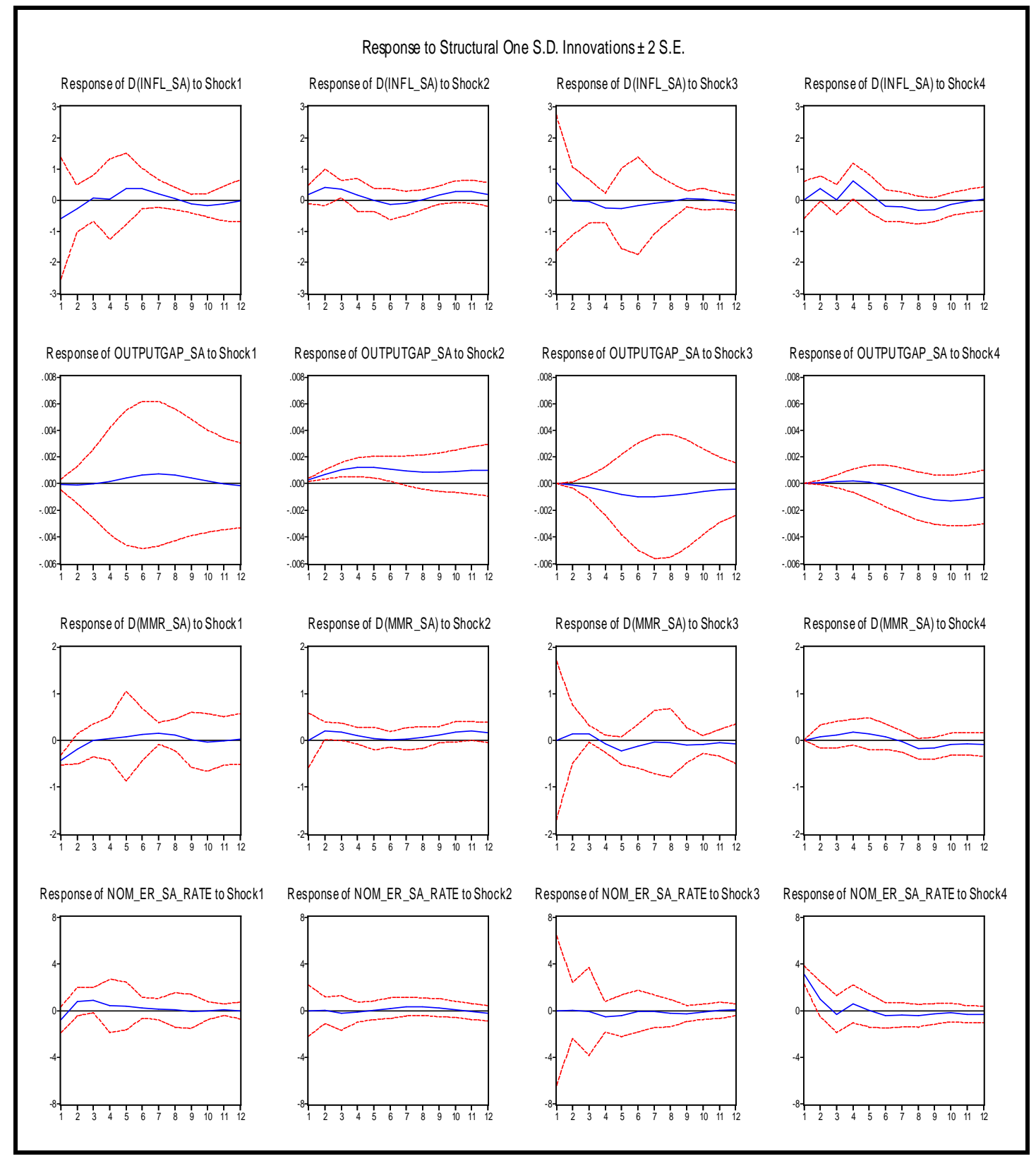


Figure (B-B5): Brazil: Impulse Response From VAR for the Pre-Inflation Targeting Period

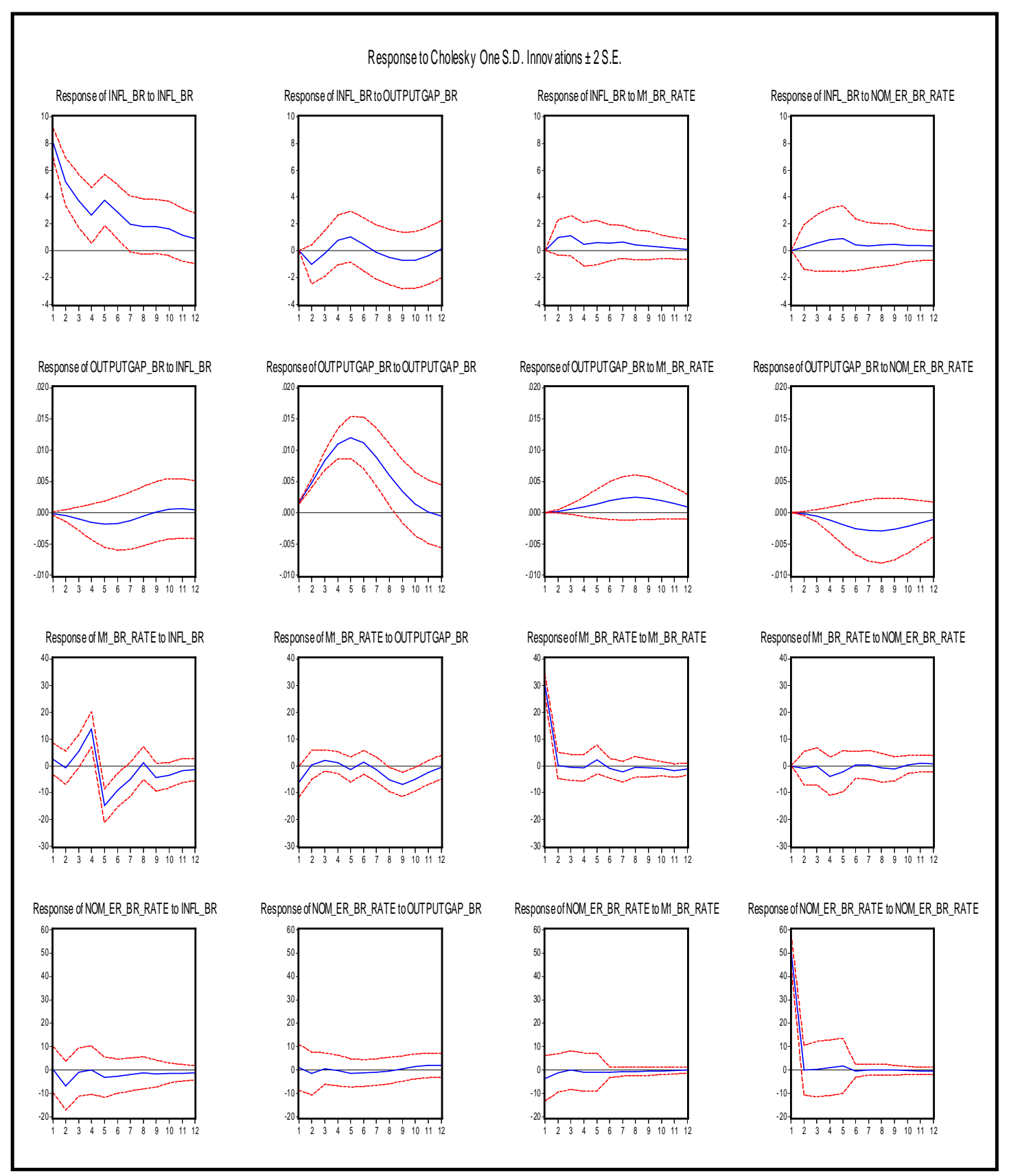

Note: This estimated VAR covers the pre-inflation targeting period. The sample spans from 1970:Q1 to 1999:Q2. The variables used in this VAR were inflation rate (infl_br), output gap (outputgap_br), and the percentage change of the log transformation of the monetary aggregate $M_{1},\left(m 1 \_b r_{-} r a t e\right)$, and that of the nominal exchange rate (nom_er_br_rate).Depending on Schwarz Information Criterion (SC), the lag length was 4 lags. 
Figure (B-B6): Brazil: Impulse Response From VAR for the Inflation Targeting Period

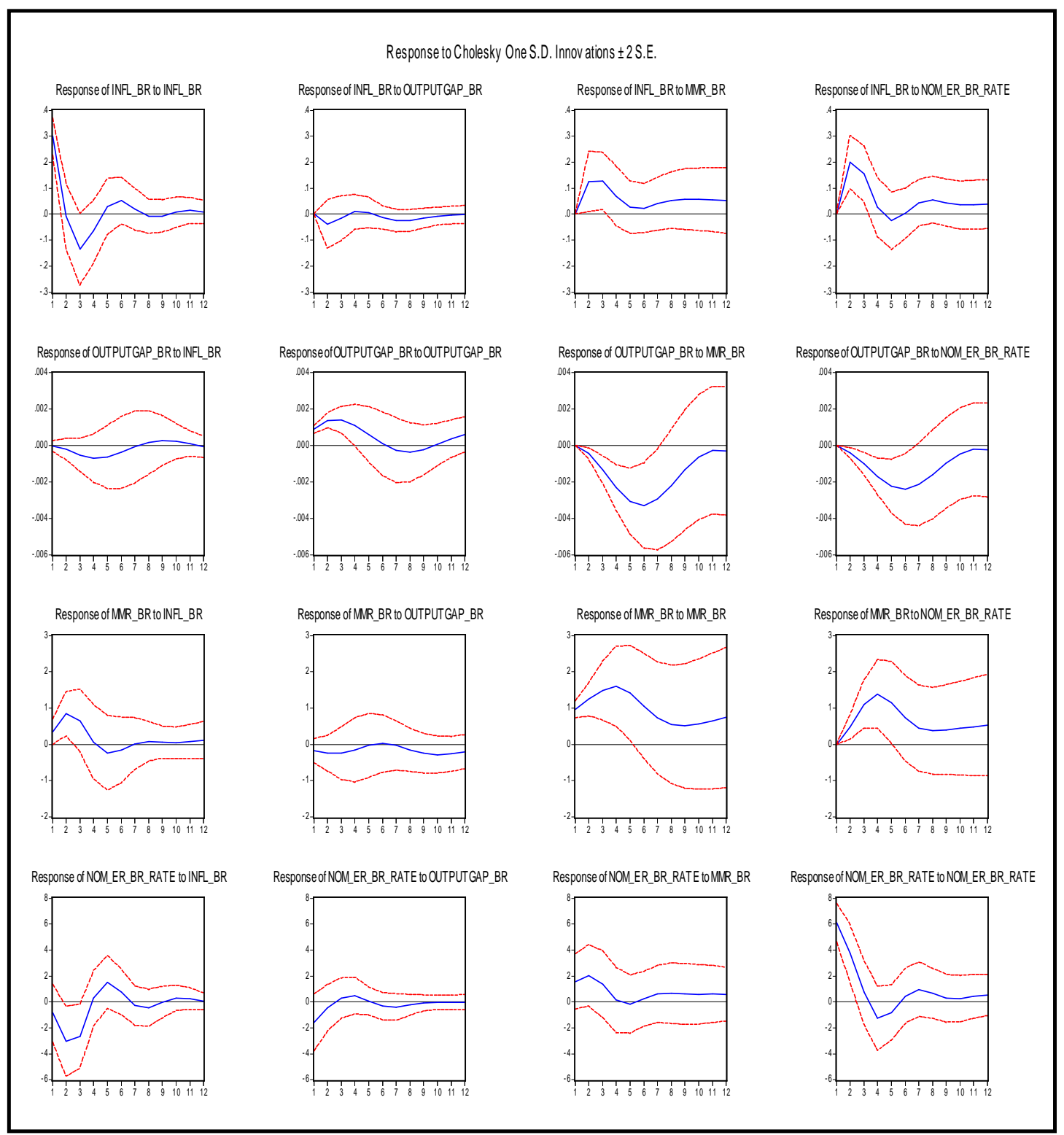

Note: The sample spans from 1999:Q3 to 2007:Q4. The VAR is estimated for the period of inflation targeting adoption, using the variables (infl br), (outputgap br) and). However, this time instead of monetary aggregate series, I used the money market rate (mmr_br) and finally I used nom_er_br_rate. The lag specification was 2 lags depending on the Schwarz Information Criterion. 
Figure (B-B7): Chile :Variance Decomposition From VAR for the Pre-Inflation Targeting Period

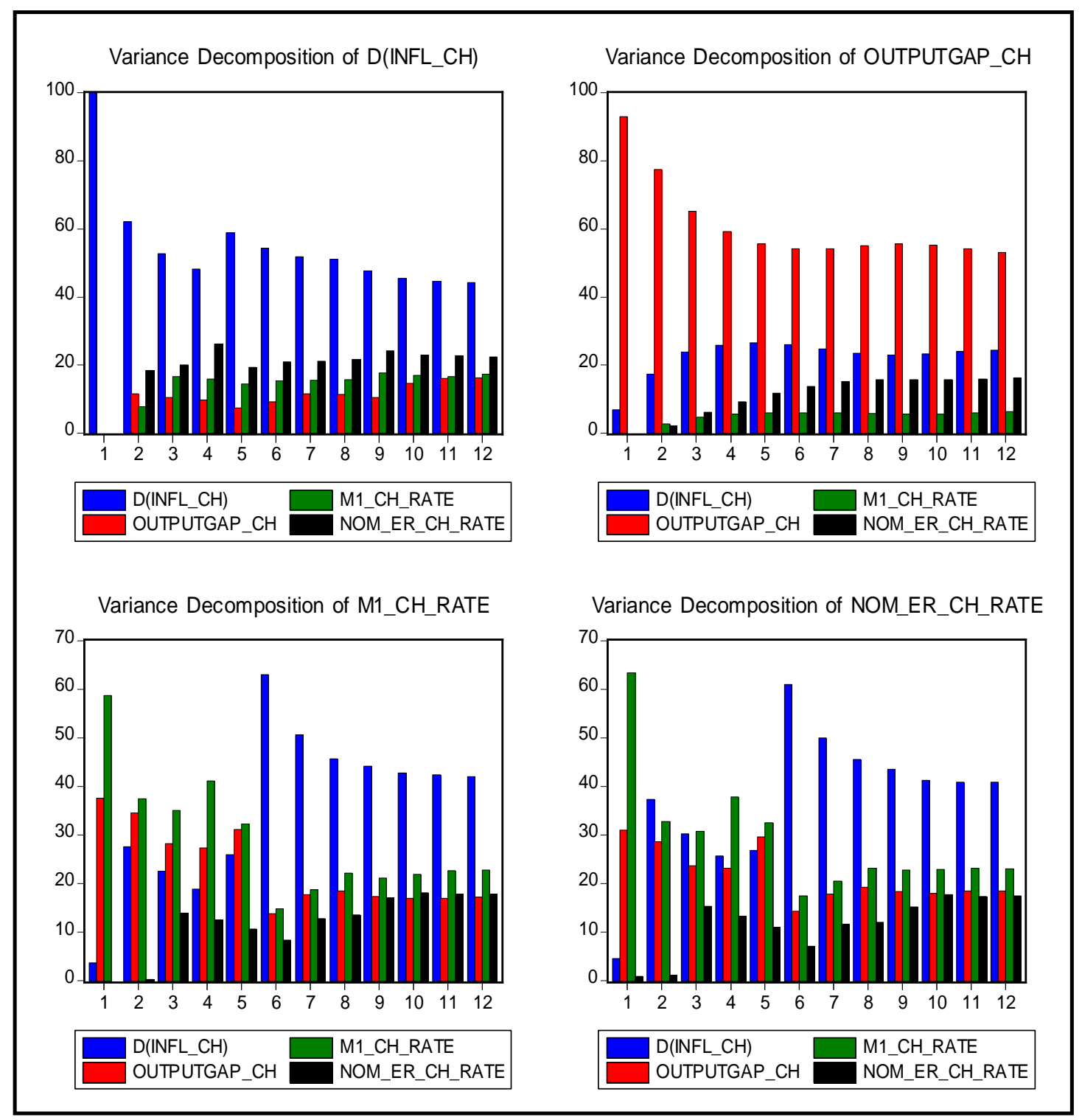

Note: The used sample spans from 1970:Q1 to 1990:Q, the variance decomposition provides information about the relative importance of each random innovation in affecting the variables in the VAR estimated for the pre-inflation targeting period. It shows that own series shocks explain most of the error variance (that is the case in infl_ch, outputgap_ch, lm1_ch). However, most of the error variance in monetary aggregate and exchange rate series is explained by shocks to inflation rate. 
Figure (B-B8): Chile: Impulse Response From VAR for the Pre-Inflation Targeting Period

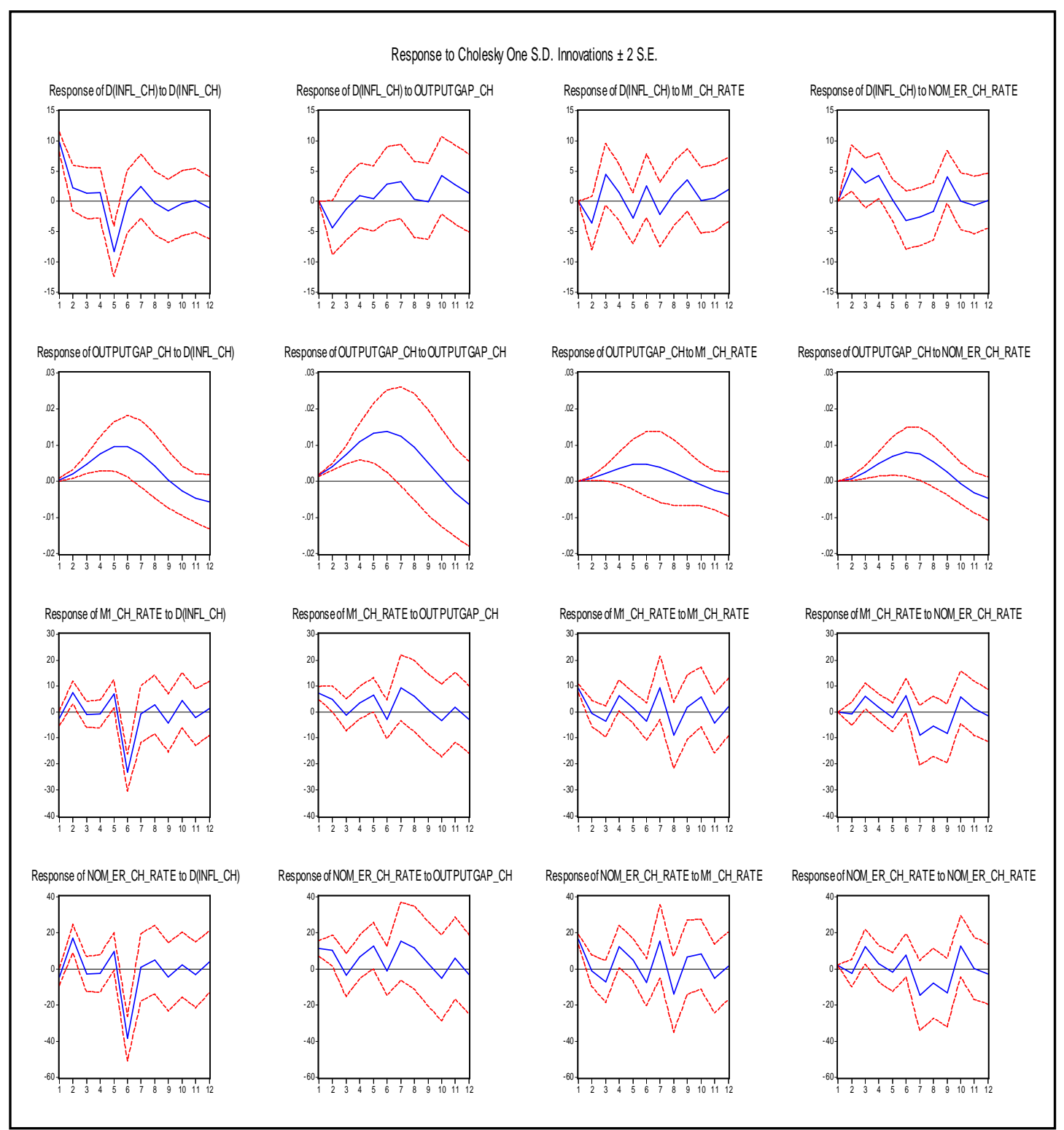

Note: the used data spans from 1970:Q1 to 1990:Q3, the variables in the VAR estimated for the pre-inflation targeting period were four variables. The first difference of inflation rates d(infl_ch), output gap (outputgap_ch), the rate of change of the logarithmic transformation of the monetary aggregate $M 1\left(m 1 \_c h \_r a t e\right)$ and that of the nominal exchange rate (nom_er_ch_rate).The lag specification was 12 using (SC) criterion. 
Figure (B-B9): Chile: Variance Decomposition From VAR for the Inflation Targeting Period

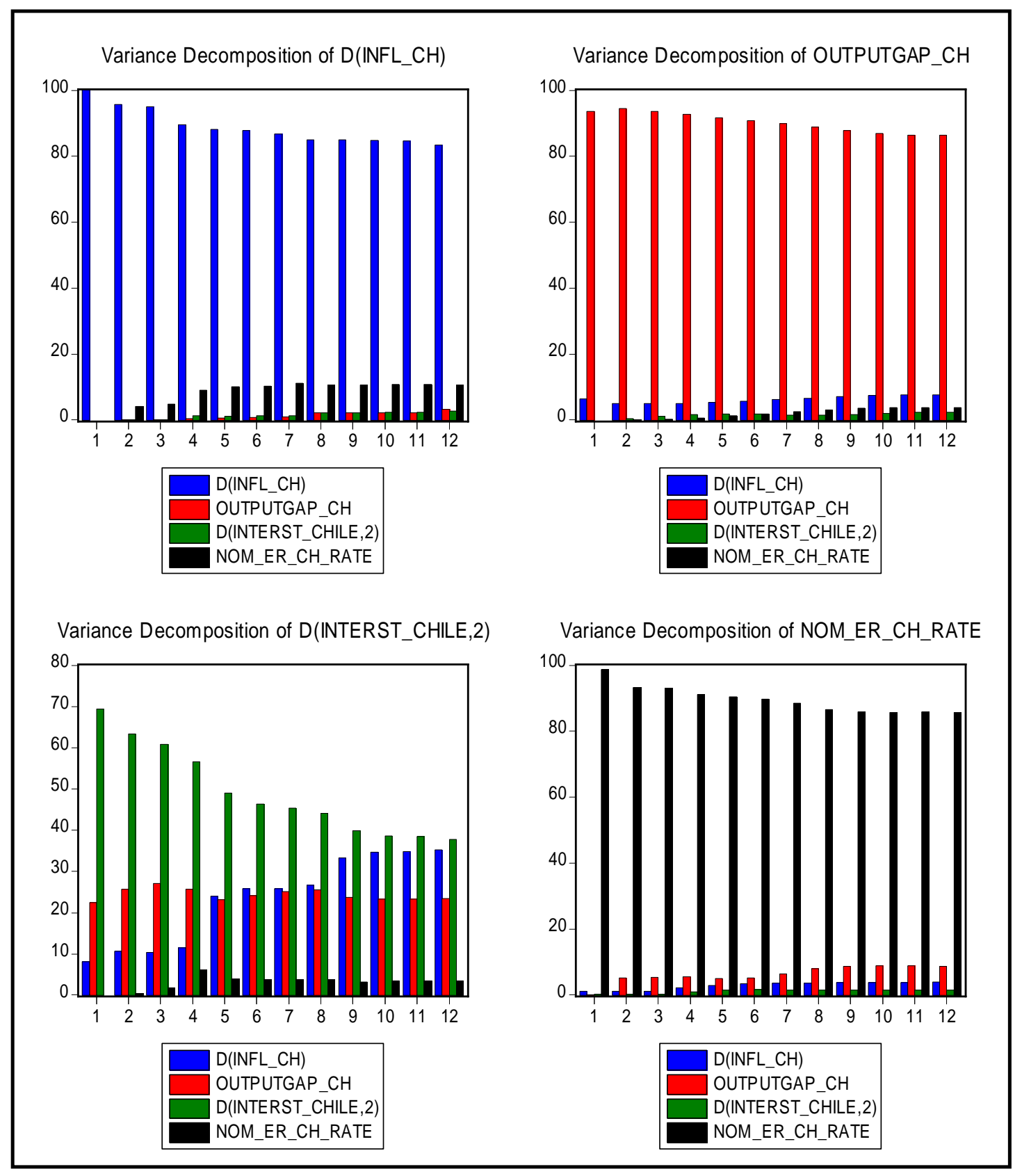

Note: The variance decomposition provides information about the relative importance of each random innovation in affecting the variables in the VAR estimated for the inflation targeting period that spans from 1990:Q4 to 2007:Q4. It shows that own series shocks explain most of the error variance (that is the case in all the four series). 
Figure (B-B10): Chile: Impulse Response From VAR for the Inflation Targeting Period

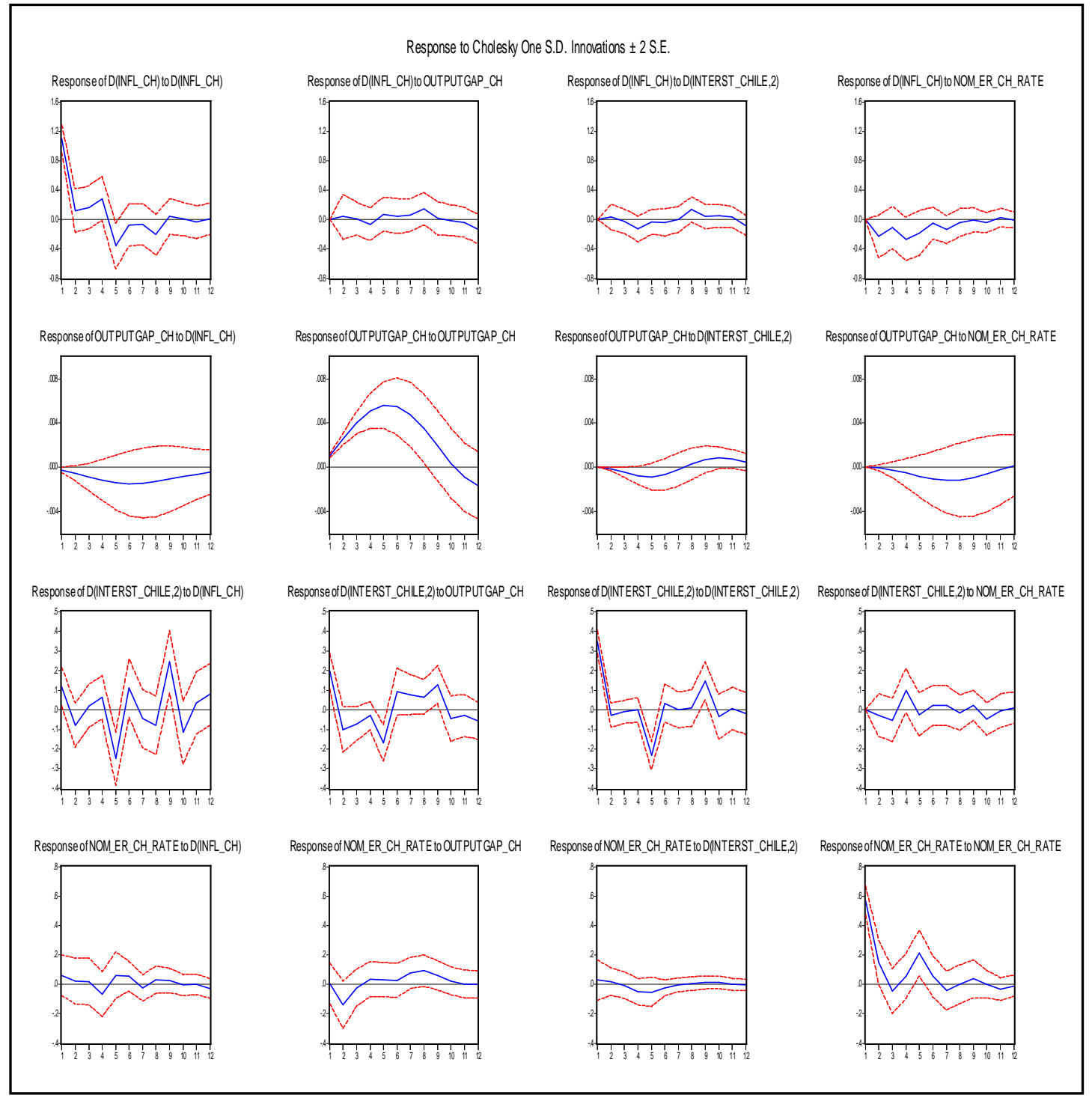

Note: the used data spans from 1990:Q4 to 2007:Q4, the variables in the VAR estimated for the inflation targeting period were

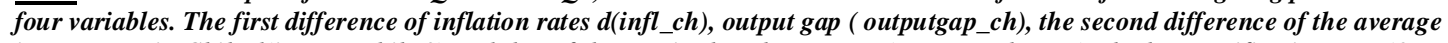
interest rate in Chile d(interest,chile,2) and that of the nominal exchange rate (nom_er_ch_rate).The lag specification was 12 using (SC) criterion. 


\section{DAVIDSON INSTITUTE WORKING PAPER SERIES - Most Recent Papers}

The entire Working Paper Series may be downloaded free of charge at: $\underline{w w w . w d i . u m i c h . e d u}$

CURRENT AS OF $12 / 9 / 10$

\begin{tabular}{|c|c|c|}
\hline Publication & Authors & Date \\
\hline $\begin{array}{l}\text { No. 1004: Inflation Targeting in Brazil, Chile \& South Africa: An } \\
\text { Empirical Investigation of Their Monetary Policy Framework }\end{array}$ & Mona Kamal & Nov. 2010 \\
\hline $\begin{array}{l}\text { No. 1003: Assessing Mondragon: Stability and Managed Change in the } \\
\text { Face of Globalization }\end{array}$ & $\begin{array}{l}\text { Saioa Arando, Fred Freundlich, } \\
\text { Monica Gago, Derek C. Jones } \\
\text { and Takao Kato }\end{array}$ & Nov. 2010 \\
\hline $\begin{array}{l}\text { No. 1002: Money Market Integration and Sovereign CDS Spreads } \\
\text { Dynamics in the New EU States }\end{array}$ & $\begin{array}{l}\text { Peter Chobanov, Amine Lahiani } \\
\text { and Nikolay Nenovsky }\end{array}$ & Oct 2010 \\
\hline No. 1001: Modeling transition in Central Asia: the Case of Kazakhstan & $\begin{array}{l}\text { Gilles DUFRENOT, Adelya } \\
\text { OSPANOVA, Alain SAND- } \\
\text { Zantman }\end{array}$ & Oct 2010 \\
\hline $\begin{array}{l}\text { No.1000: Unlocking Productive Entrepreneurship in Ethiopia: } \\
\text { Which Incentives Matter? }\end{array}$ & $\begin{array}{l}\text { Zuzana Brixiova \& } \\
\text { Emerta Asaminew }\end{array}$ & Oct 2010 \\
\hline No.999: Price convergence and market integration in Russia & Konstantin Gluschenko & Sept 2010 \\
\hline $\begin{array}{l}\text { No. 998: Bank Efficiency in Transitional Countries: Sensitivity to } \\
\text { Stochastic Frontier Design }\end{array}$ & Zuzana Irsova & Sept 2010 \\
\hline $\begin{array}{l}\text { No. 997: EU Enlargement and Monetary Regimes from the Insurance } \\
\text { Model Perspectives }\end{array}$ & Nikolay Nenovsky & June 2010 \\
\hline $\begin{array}{l}\text { No. 996: Which Foreigners are Worth Wooing? } \\
\text { A Meta-Analysis of Vertical Spillovers from FDI }\end{array}$ & $\begin{array}{l}\text { Tomas Havranek and } \\
\text { Zuzana Irsova }\end{array}$ & June 2010 \\
\hline $\begin{array}{l}\text { No. 995: Environmental Regulation and Competitiveness: } \\
\text { Evidence from Romania }\end{array}$ & $\begin{array}{c}\text { Guglielmo M. Caporale, } \\
\text { Christophe Rault, Robert Sova \& } \\
\text { Anamaria Sova } \\
\end{array}$ & June 2010 \\
\hline $\begin{array}{l}\text { No. 994: Pollution Abatement And Control Expenditure In Romania: } \\
\text { A Multilevel Analysis }\end{array}$ & $\begin{array}{c}\text { Guglielmo M. Caporale, } \\
\text { Christophe Rault, Robert Sova \& } \\
\text { Anamaria Sova }\end{array}$ & June 2010 \\
\hline $\begin{array}{l}\text { No. 993: Do Innovative Workplace Practices Foster Mutual Gains? } \\
\text { Evidence From Croatia }\end{array}$ & Derek Jones and Srecko Goic & May 2010 \\
\hline $\begin{array}{l}\text { No. 992: Firm And Employee Effects Of An Enterprise Information } \\
\text { System: Micro-Econometric Evidence }\end{array}$ & $\begin{array}{l}\text { Derek Jones, Panu Kalmi } \\
\text { and Antti Kauhanen }\end{array}$ & June 2010 \\
\hline $\begin{array}{l}\text { No. 991: Catching-up and inflation in Europe: Balassa- } \\
\text { Samuelson, Engel's Law and other Culprits }\end{array}$ & Balázs Égert & June 2010 \\
\hline $\begin{array}{l}\text { No. 990: UNLOCKING PRODUCTIVE ENTREPRENEURSHIP IN AFRICA'S LEAST } \\
\text { DEVELOPED COUNTRIES }\end{array}$ & Zuzana Brixiova & June 2010 \\
\hline $\begin{array}{l}\text { No. 989: The VARying Effect of Foreign Shocks in Central \& Eastern } \\
\text { Europe }\end{array}$ & $\begin{array}{l}\text { Rebeca Jimenez-Rodriguez, } \\
\text { Amalia Morales-Zumaquero } \\
\text { \& Balazs Egert }\end{array}$ & May 2010 \\
\hline $\begin{array}{l}\text { No. 988: Implications of Bank Ownership for the Credit Channel of } \\
\text { Monetary Policy Transmission: Evidence from India }\end{array}$ & $\begin{array}{l}\text { Sumon K. Bhaumik, Vinh Dang } \\
\text { and Ali M. Kutan }\end{array}$ & May 2010 \\
\hline $\begin{array}{l}\text { No. 987: Mother or motherland: Can a government have an impact on } \\
\text { educational attainment of the population? Preliminary evidence from } \\
\text { India }\end{array}$ & $\begin{array}{l}\text { Sumon Kumar Bhaumik and } \\
\text { Manisha Chakrabarty }\end{array}$ & May 2010 \\
\hline $\begin{array}{l}\text { No. 986: Does FDI spur innovation, productivity and knowledge sourcing } \\
\text { by incumbent firms? Evidence from manufacturing industry in Estonia }\end{array}$ & Priit Vahter & April 2010 \\
\hline No. 985: Exports and Property Prices in France: Are They Connected? & $\begin{array}{c}\text { Balazs Egert and } \\
\text { Rafal Kierzenkowski }\end{array}$ & May 2010 \\
\hline $\begin{array}{l}\text { No. 984: Methodologies of Analyzing Inter-Regional Income Inequality } \\
\text { and Their Applications to Russia }\end{array}$ & Konstantin Gluschenko & April 2010 \\
\hline $\begin{array}{l}\text { No. 983: Foreign News and Spillovers in Emerging European Stock } \\
\text { Markets }\end{array}$ & Evzen Kocenda and Jan Hanousek & $\begin{array}{l}\text { May } \\
2010\end{array}$ \\
\hline
\end{tabular}

